\author{
UNIVERSIDADE DE SÃO PAULO \\ ESCOLA DE ENGENHARIA DE LORENA - EEL
}

VICTOR DANIEL DE SALLES SANTOS

Desenvolvimento de uma formulação probiótica para a prevenção e tratamento

da mastite em bovinos

Lorena - SP

2015 



\title{
Desenvolvimento de uma formulação probiótica para a prevenção e tratamento da mastite em bovinos
}

\begin{abstract}
Dissertação apresentada à Escola de Engenharia de Lorena da Universidade de São Paulo para a obtenção do título de Mestre em Ciências do Programa de Pós-Graduação em Biotecnologia Industrial na área de concentração de Microbiologia Aplicada.
\end{abstract}

Orientador: Prof. Dr. Ismael Maciel de Mancilha

Edição reimpressa e corrigida

Lorena - SP

Novembro, 2015 
AUTORIZO A REPRODUÇÃO E DIVULGAÇÃO TOTAL OU PARCIAL DESTE TRABALHO, POR QUALQUER MEIO CONVENCIONAL OU ELETRÔNICO, PARA FINS DE ESTUDO E PESQUISA, DESDE QUE CITADA A FONTE

Ficha catalográfica elaborada pelo Sistema Automatizado da Escola de Engenharia de Lorena, com os dados fornecidos pelo(a) autor(a)

Santos, Victor Daniel de Salles

Desenvolvimento de uma formulação probiótica para a prevenção e tratamento da mastite em bovinos / Victor Daniel de Salles Santos; orientador Ismael Maciel de Mancilha - ed. reimp., corr. - Lorena, 2015. $101 \mathrm{p}$.

Dissertação (Mestrado em Ciências - Programa de Pós Graduação em Biotecnologia Industrial na Área de Microbiologia Aplicada) - Escola de Engenharia de Lorena da Universidade de São Paulo. 2015

Orientador: Ismael Maciel de Mancilha

1. Probióticos. 2. Mastite. 3. Emulsão. 4. Preparação probiótica. I. Título. II. Mancilha, Ismael Maciel de, orient. 
Dedico esta dissertação a minha esposa Andréa, minha filha Manuela e aos meus pais Silvio e Djanira. 



\section{AGRADECIMENTOS}

A minha esposa Andréa Tiengo pela amizade, apoio e incentivo durante as dificuldades, e por me presentear com nossa princesa Manuela no final desta jornada.

Aos meus pais Silvio e Djanira pela ajuda e suporte nos momentos mais difíceis.

Ao meu orientador Prof. Dr. Ismael Maciel de Mancilha por acreditar no meu trabalho e pela paciência e apoio para corrigir minhas deficiências.

Aos amigos Cláudio Donato de Oliveira Santos, pelo apoio durante o desenvolvimento deste trabalho, e Juan Daniel Rivaldi pela força com a dissertação. 



\section{BIOGRAFIA}

Victor Daniel de Salles Santos nasceu no dia 20 de Abril de 1977, na cidade de Caçapava - SP. Em 1996, com 18 anos, ingressou no curso de Farmácia da Escola de Farmácia e Odontologia de Alfenas (EFOA), hoje UNIFAL. Durante o curso teve a oportunidade de realizar estágio na CIMED Indústria de Medicamentos em Pouso Alegre MG, onde foi efetivado e trabalhou por um ano.

No ano de 2002, deixou o setor de farmácia industrial e estabeleceu na cidade de Itajubá - MG a Pharmatus Farmácia com manipulação, onde ainda trabalha como farmacêutico responsável e sócio-proprietário.

Em 2006, iniciou na carreira docente como professor do curso de farmácia da FEPI - Centro Universitário de Itajubá, onde ainda ministra as disciplinas de farmacoténica, cosmetologia, tecnologia farmacêutica e controle físico-químico.

Em 2007, iniciou estudos de pós-graduação latu sensu em botânica na Universidade Federal de Lavras - MG, concluído em 2008.

No ano de 2013, iniciou o mestrado no Programa de Pós-Graduação em Biotecnologia Industrial da Escola de Engenharia de Lorena - EEL/USP, onde desenvolveu um trabalho envolvendo preparações probióticas para tratamento de mastite bovina.

Em 2015 foi contratado pela FATEA - Faculdades Integradas Tereza D’Ávila, em Lorena - SP, como professor das disciplinas de farmacotécnica e cosmetologia. 



\section{RESUMO}

SANTOS, V. D. S. Desenvolvimento de uma formulação probiótica para a prevenção e tratamento da mastite em bovinos. 2015. 101p. Dissertação (Mestrado em Ciências) Escola de Engenharia de Lorena, Universidade de São Paulo, Lorena, 2015.

O Brasil é o quinto maior produtor de leite do mundo, entretanto sua produtividade é considerada baixa. Um dos motivos desta baixa produtividade é a alta incidência da mastite no rebanho. A mastite é a reação inflamatória da glândula mamária, causada principalmente pela invasão e ação de espécies de micro-organismos patogênicos. $\mathrm{O}$ principal tratamento consiste no uso de antibióticos de aplicação intramamária. Entretanto, o uso constante de antibióticos apresenta problemas graves como o surgimento de cepas de bactérias resistentes e a presença de resíduos destes medicamentos no leite. Para reduzir esses problemas, formas alternativas de prevenção e tratamento da mastite têm sido estudadas, como o uso de preparações contendo espécies probióticas. Pesquisas recentes têm demonstrado o potencial de algumas destas espécies no tratamento e prevenção da mastite bovina tendo em vista sua atividade inibitória sobre os patógenos responsáveis por esta infecção. Desta forma, a proposta deste estudo foi desenvolver e avaliar a estabilidade de uma preparação probiótica na forma de emulsão de aplicação intramamária contendo $10^{8} \mathrm{UFC} / \mathrm{mL}$ de um "pool" constituído de cinco cepas de Lactobacillus (L. acidophilus ATCC 4356, L. casei ATCC 7469, L. fermentum ATCC 9338, L. plantarum ATCC $8014 \mathrm{e}$ $L$. paracasei Nestlé ST11). Para tanto, 12 formulações de emulsão base foram desenvolvidas e avaliadas em ensaios preliminares de estabilidade (centrifugação e estresse térmico), sendo a formulação contendo monestearato de glicerila, lanolina anidra, óleo mineral, Tween $80^{\circledR}$ e Spam $80^{\circledR}$ selecionada para formulação da preparação probiótica. Adicionalmente, selecionou-se como agente conservante sorbato de potássio visando aumentar a vida útil da preparação probiótica. A preparação, assim desenvolvida, foi submetida ao teste de estabilidade físico-químico por 90 dias a $50^{\circ} \mathrm{C} \pm 2^{\circ} \mathrm{C}$. Observou-se que o aspecto da preparação se manteve estável, mas com redução nos parâmetros $\mathrm{pH}$, densidade e aumento na viscosidade. A manutenção da viabilidade dos Lactobacillus na preparação foi estudada em um ensaio de 120 dias, sendo avaliada a influência dos fatores: temperatura de estocagem, adição de sacarose e sorbato de potássio. Observou-se influência significativa da temperatura demonstrando a importância da refrigeração na manutenção na viabilidade dos Lactobacillus. Verificou-se também que, sob refrigeração, a adição de sacarose promoveu redução de 0,5 ciclo logarítmico em relação a população inicial de células viáveis. Observou-se redução do $\mathrm{pH}$ da preparação probiótica avaliada nestas condições. Estes resultados permitem concluir que a refrigeração da preparação é indispensável para a manutenção da viabilidade das bactérias probióticas. A adição de $2 \%$ de sacarose à preparação, mantida sob refrigeração, se mostrou eficiente na manutenção da população de células viáveis ao final de 120 dias de ensaio, contendo $10^{8} \mathrm{UFC} / \mathrm{g}$, característica desejável para um produto probiótico.

Palavras-chave: Probióticos; Mastite; Emulsão; Preparação probiótica. 


\begin{abstract}
SANTOS, V. D. S. Development of a probiotic formulation for the prevention and treatment of bovine mastitis. 2015. 101p. Dissertation (Master of Science) - Escola de Engenharia de Lorena, Universidade de São Paulo, Lorena, 2015.
\end{abstract}

Brazil is the world's fifth largest milk producer, though its productivity has been considered low. One of the reasons for this low productivity is the high incidence of mastitis in the herd. Mastitis is the inflammation of the mammary gland, mainly caused by the invasion and action of pathogenic microorganisms. The treatment is accomplished through the use of intramammary application of antibiotics. However, the constant use of antibiotics has serious problems such as the emergence of resistant strains of bacteria and the presence of residues of these drugs in milk. To reduce these problems, alternative means of prevention and treatment of mastitis has been studied as the use of preparations containing probiotic species. Recent studies have demonstrated the potential of some of these species in the treatment and prevention of bovine mastitis due to their inhibitory activity on pathogen species responsible for the infection. Thus, the purpose of this study was to develop and evaluate the stability of probiotic preparation in the form of intramammary application emulsion containing $10^{8} \mathrm{CFU} / \mathrm{mL}$ of five Lactobacillus strains (L. acidophilus ATCC 4356, L. casei ATCC 7469 L. fermentum ATCC 9338, ATCC 8014, L. plantarum and L. paracasei ST11 Nestle). Therefore, 12 basic emulsion formulations were developed and evaluated in preliminary tests for stability (thermal stress and centrifugation), and only one was selected. Additionally, potassium sorbate was selected as preservative in order to increase the shelf life of the preparation. The developed preparation was subjected to study the physicochemical stability for 90 days at $50^{\circ} \mathrm{C} \pm 2{ }^{\circ}$ $\mathrm{C}$. The results showed that the aspect of the preparation remained stable, but decreasing in $\mathrm{pH}$ and density and increasing in viscosity. The maintenance of the viability of the lactobacillus in the preparation was studied in a 120-day test, and flowing factors were considered: storage temperature, sucrose addition and the potassium sorbate addition. It was observed that there was significant differences in the temperature factor demonstrating the importance of cooling in maintaining the viability of Lactobacillus. It was also observed that sucrose decreased by $0,5 \mathrm{log}$ cycle compared to initial population of viable cells in the refrigerated preparation. Regarding the $\mathrm{pH}$, it was noted a decrease in the different formulations evaluated. These results show that the cooling of the preparation is indispensable for maintaining the viability of probiotic bacteria. The addition of $2 \%$ sucrose to the preparation proved efficient with a slower decrease in viability maintaining the population of viable cells at the end of the 120 days of the assay.

Keywords: Probiotics; Mastitis; Emulsion; Probiotic preparation. 


\section{LISTA DE FIGURAS}

Figura 1. Sistema de suporte do úbere bovino e separação dos quartos mamários .............26

Figura 2. Glândula mamária, sistema de ductos e teto ......................................................2

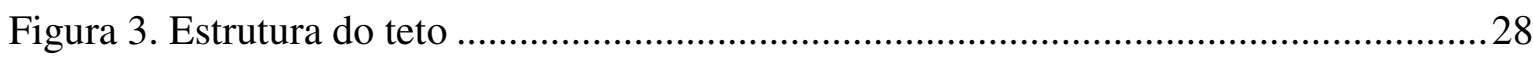

Figura 4. Fluxograma do desenvolvimento da formulação probiótica .................................51

Figura 5. Fluxograma de produção da emulsão base...........................................................55

Figura 6. Fluxograma do preparo do pool de Lactobacillus ..............................................57

Figura 7. Fluxograma do ensaio de seleção do conservante .................................................59

Figura 8. Fluxograma da produção da emulsão base esterilizada........................................61

Figura 9. Variação da população de células viáveis das cepas contidas na preparação probiótica na presença de diferentes inibidores................................................................. 72

Figura 10. Variação da população de células viáveis nas preparações avaliadas nas

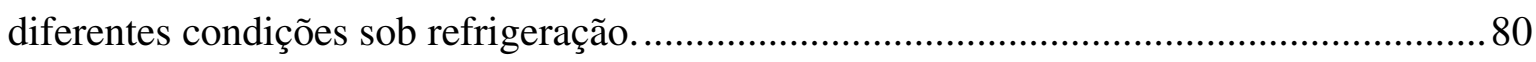




\section{LISTA DE TABELAS}

Tabela 1. Agentes emulsificantes avaliados no desenvolvimento da emulsão base e valores de EHL

Tabela 2. Componentes oleosos avaliados no desenvolvimento da emulsão base, valores de EHL e concentrações avaliadas. .52

Tabela 3. Componentes hidrossolúveis utilizados no desenvolvimento da emulsão base e concentrações avaliadas .53

Tabela 4. Composição das emulsões base desenvolvidas .54

Tabela 5. Formulação da emulsão base 60

Tabela 6. Avaliação dos parâmetros físicos das 12 formulações desenvolvidas. .68

Tabela 7. Parâmetros físicos das formulações 5, 11 e 12 submetidas aos ensaios de centrifugação e estresse térmico da estabilidade preliminar. . .70

Tabela 8. População de células viáveis e taxa de sobrevivência das bactérias contidas na preparação probiótica na presença de inibidores.

Tabela 9. Valores de $\mathrm{pH}$ da preparação probiótica na presença de diferentes agentes inibidores .74

Tabela 10. Variação dos parâmetros físico-químicos da preparação probiótica submetida a $50^{\circ} \mathrm{C} \pm 2^{\circ} \mathrm{C}$ por 90 dias. .76

Tabela 11. População de células de Lactobacillus submetidas a diferentes tratamentos durante 120 dias de ensaio .79

Tabela 12. Variação do pH nos oito tratamentos experimentais durante 120 dias de ensaio. 


\section{LISTA DE ABREVIATURAS}

A/O: água em óleo

ABIA: Associação Brasileira das Indústrias de Alimentos

ANVISA: Agência Nacional de Vigilância Sanitária

BAL: bactérias ácido láticas

CBM: Concentração Bactericida Mínima

CCS: contagem de células somáticas

$\mathrm{CH}$ : centesimal hahnemanniana

CIM: Concentração Inibitória Mínima

CMT: California Mastitis Test

CPV: Coordenação de Fiscalização de Produtos Veterinários

CS: células somáticas

EHL: equilíbrio hidrófilo-lipófilo

EMBRAPA: Empresa Brasileira de Pesquisa Agropecuária

EPS: exopolissacarídeos

FAO: Organização de Alimentos e Agricultura das Nações Unidas (FAO)

FDA: Food and Drug Administration

FOS: frutoligosacarídeo

IBGE: Instituto Brasileiro de Geografia e Estatística

LMR: Limites Máximos de Resíduos

MAPA: Ministério da Agricultura, Pecuária e Abastecimento

MRS: Man, Rogosa e Sharpe

O/A: óleo em água

OMGE: Organização Mundial de Gastroenterologia

OMS: Organização Mundial da Saúde

PMN: células polimorfonucleares 
RDC: resolução da diretoria colegiada

SIDAN: Sindicato Nacional da Indústria de Produtos para Saúde Animal

UFC: unidades formadoras de colônia

UHT: ultra high temperature

UR: umidade relativa 


\section{SUMÁRIO}

1. INTRODUÇÃ

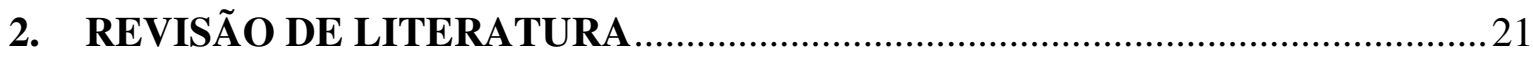

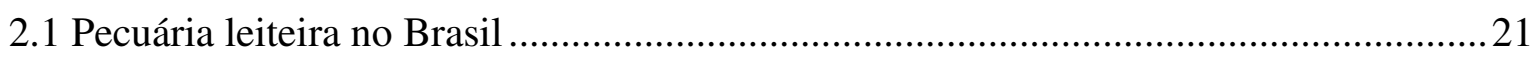

2.2 Mercado brasileiro de produtos veterinários ……………………………………....22

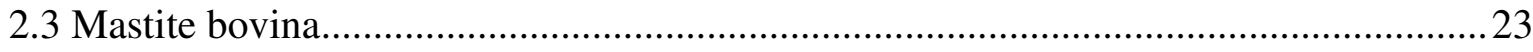

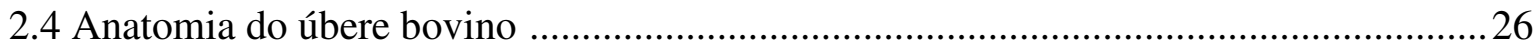

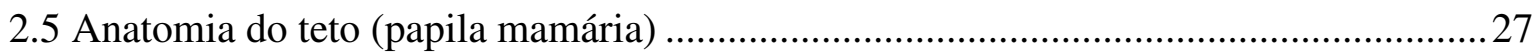

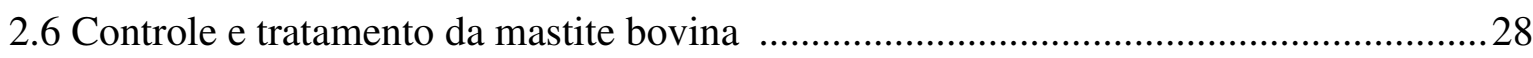

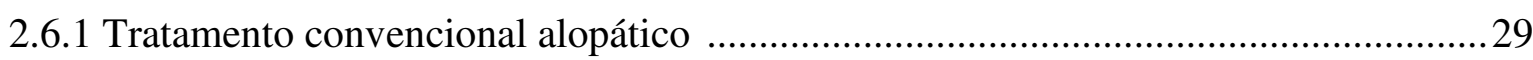

2.6.2 Alternativas ao tratamento alopático ……………………………………………...... 31

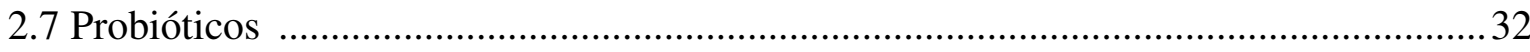

2.7.1 Mecanismos de ação ........................................................................................ 34

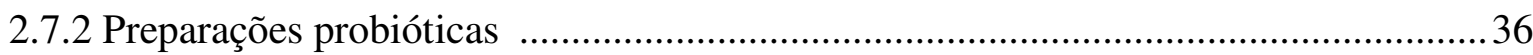

2.7.3 Probióticos no tratamento e prevenção da mastite …………………………………....37

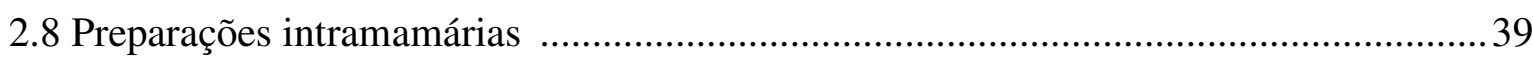

2.9 Emulsões farmacêutica …………………………………………………………..... 40

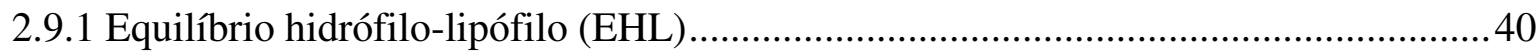

2.9.2 Estabilidade das emulsões ................................................................................

2.9.3 Estudo da estabilidade acelerada .........................................................................4

2.9.4 Estudo da estabilidade de longa duração ...............................................................4

2.9.5 Componentes da emulsão .............................................................................. 43

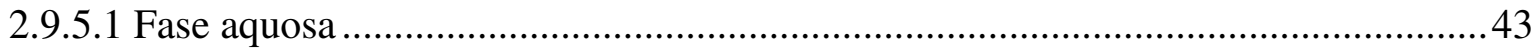

2.9.5.1.1 Hidroxietilcelulose .....................................................................................4

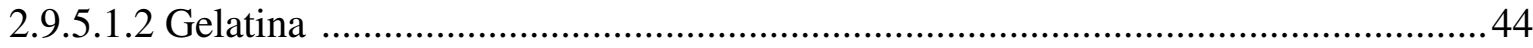

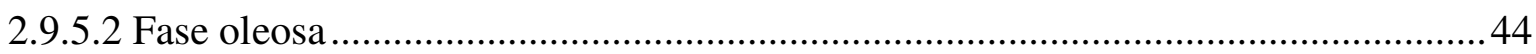

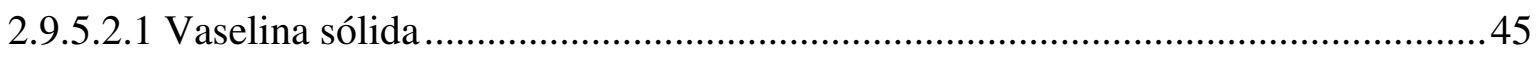

2.9.5.2.2 Vaselina líquida (óleo mineral)....................................................................4

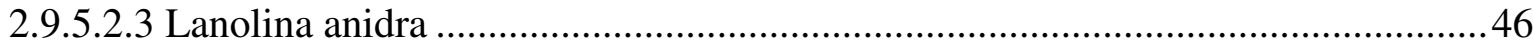

2.9.5.2.4 Monoesterato de glicerila (MEG) ................................................................4

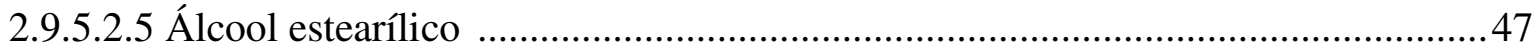

2.9.6 Agentes emulsificantes ............................................................................................4 


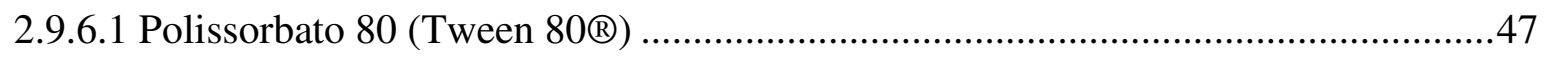

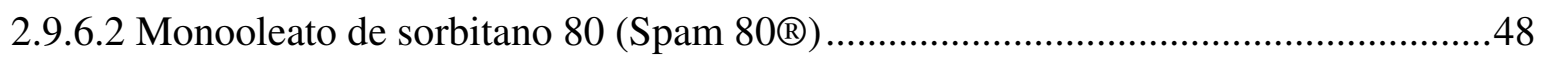

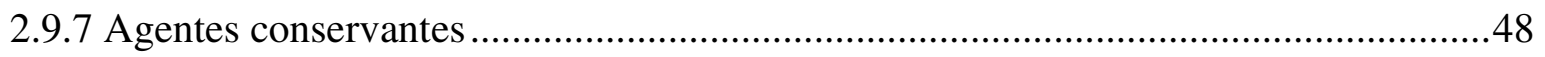

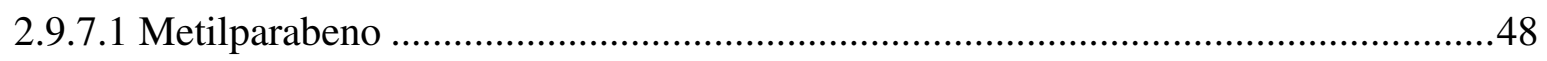

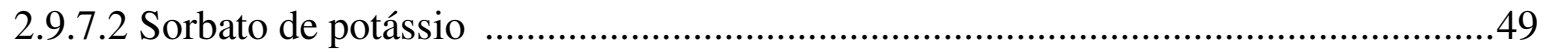

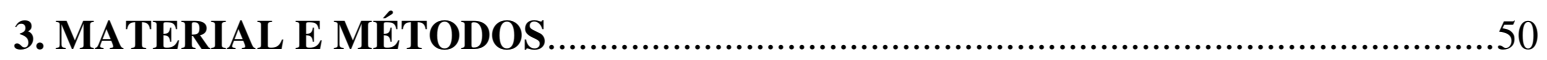

3.1 Microrganismo e desenvolvimento da formulação probiótica .....................................50

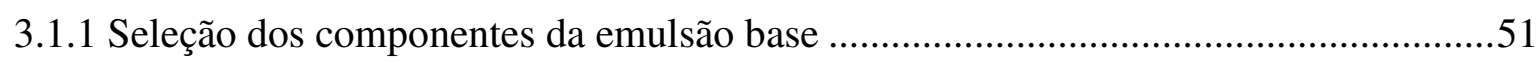

3.1.2 Desenvolvimento e manipulação da emulsão base .................................................53

3.1.3 Avaliação preliminar da estabilidade da emulsão .....................................................56

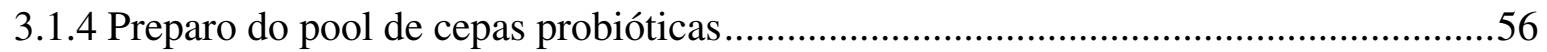

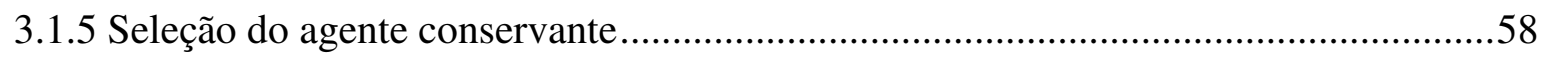

3.2 Manipulação e avaliação da estabilidade da preparação probiótica ..............................59

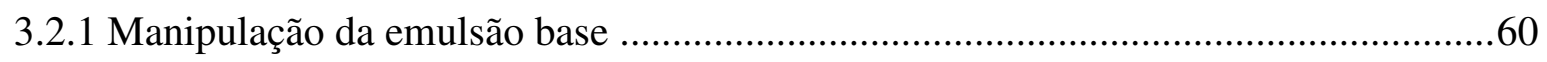

3.2.2 Manipulação da preparação probiótica e avaliação da estabilidade físico química ...61

3.2.3 Manipulação da preparação probiótica e avaliação da estabilidade microbiológica ..62

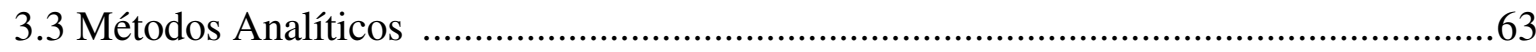

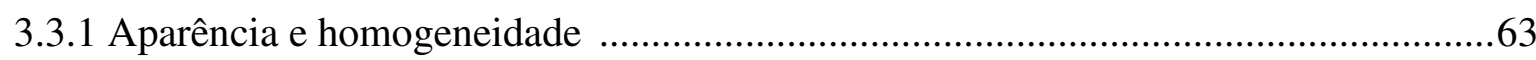

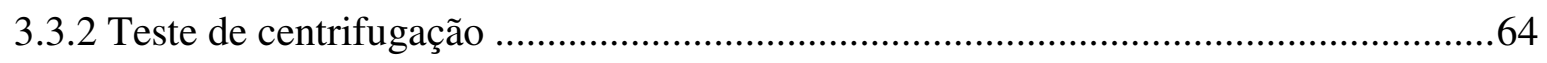

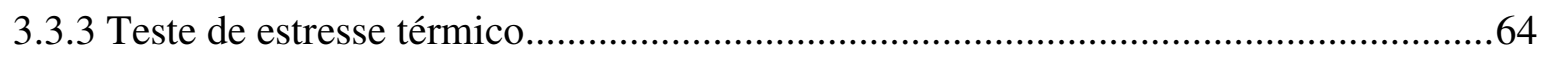

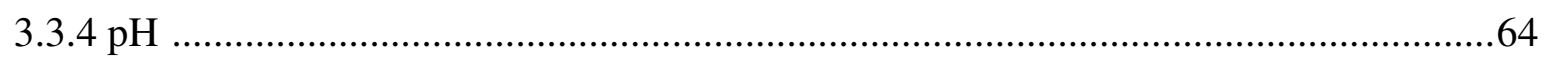

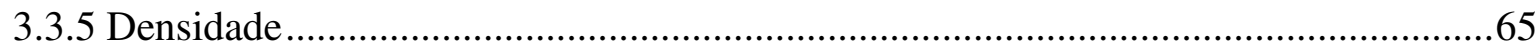

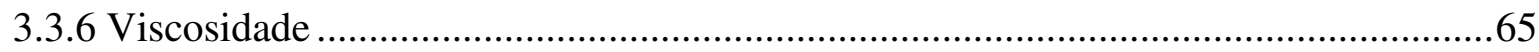

3.3.7 Determinação da população de células viáveis ........................................................66

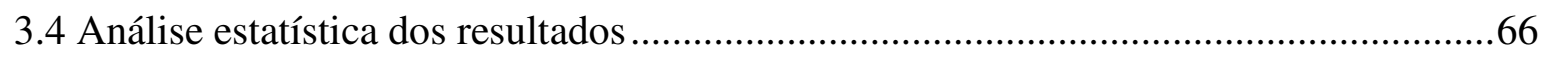

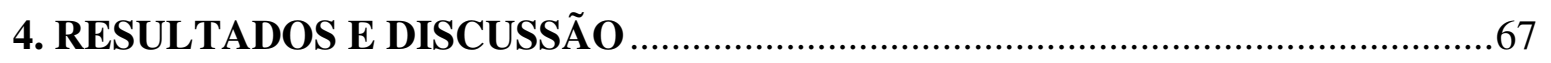

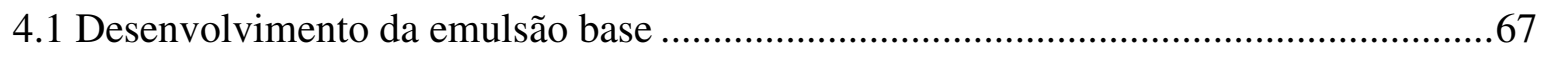

4.1.1 Avaliação preliminar da estabilidade da emulsão ....................................................69

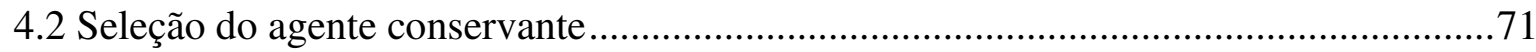

4.3 Avaliação da estabilidade físico-química da preparação probiótica ..............................74

4.4 Avaliação da estabilidade microbiológica da preparação probiótica.............................77

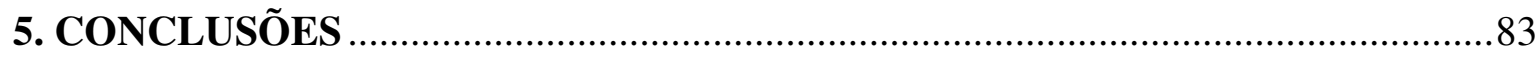

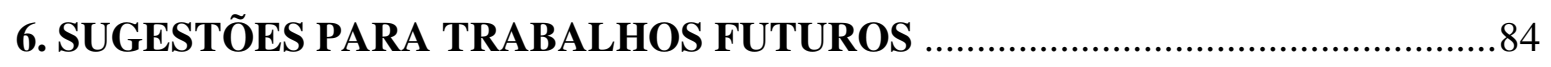




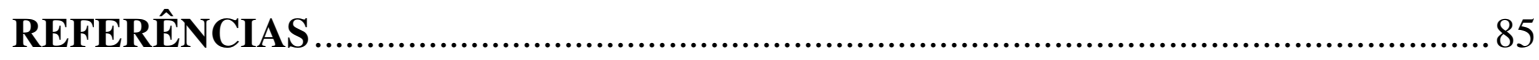

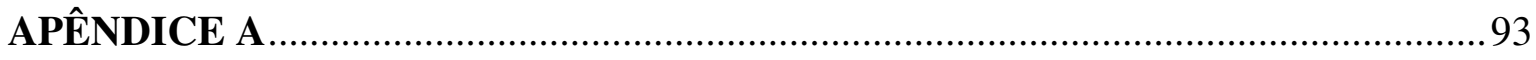

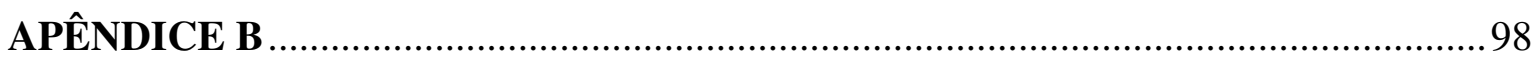





\section{INTRODUÇÃO}

O Brasil é o quinto maior produtor de leite do mundo, com 5\% da produção mundial. Apesar desta produção expressiva, a produtividade brasileira é considerada baixa quando comparada a outros países produtores, o que pode ser relacionado à baixa qualidade nutricional da alimentação do rebanho, fatores genéticos, mão de obra pouco especializada e a problemas com a sanidade do rebanho, com destaque para a alta incidência da mastite.

A mastite é a reação inflamatória da glândula mamária a agentes microbiológicos, agentes químicos, lesões térmicas ou lesões físicas, sendo a principal causa a invasão e ação de microrganismos nas glândulas mamárias. É a doença que mais acomete vacas leiteiras adultas, sendo responsável por cerca de $40 \%$ de toda a morbidade.

Algumas medidas auxiliam no sucesso de um programa de controle da mastite, como o monitoramento dos índices de mastite, isolamento das vacas com infecções crônicas, higiene, manejo correto, manutenção adequada dos equipamentos de ordenha, procedimento de pré e pós-imersão do teto em soluções antissépticas, tratamento das vacas ao secar (término da lactação) e dos casos clínicos utilizando produtos veterinários prescritos por profissional qualificado.

Os produtos veterinários são definidos pelo Ministério da Agricultura, Pecuária e Abastecimento (MAPA) como toda substância química, biológica, biotecnológica ou preparação manufaturada, cuja administração seja de forma individual ou coletiva, direta ou misturada com os alimentos, destinada à prevenção, ao diagnóstico e à cura ou ao tratamento das doenças dos animais. Segundo o Sindicato Nacional da Indústria de Produtos para Saúde Animal (SIDAN), o faturamento do mercado brasileiro de produtos veterinários passou de 2,5 bilhões de reais em 2008 para quase 4 bilhões em 2013.

Os produtos veterinários mais utilizados no tratamento da mastite bovina são os antibióticos de aplicação intramamária. É recomendável que todos os animais tenham os quartos mamários tratados com antibióticos aprovados para uso animal após a última ordenha da lactação. Entretanto, o uso constante de antibióticos no tratamento da mastite apresenta problemas graves como o surgimento de cepas de bactérias resistentes e a presença de resíduos destes medicamentos no leite produzido pelo animal tratado. 
Para reduzir esses problemas, formas alternativas de prevenção e tratamento da mastite estão sendo estudadas, como o uso de medicamentos homeopáticos, fitoterápicos, lantibióticos e preparações probióticas.

As preparações probióticas contêm microrganismos vivos que, quando administrados em dosagens apropriadas, conferem benefícios à saúde do hospedeiro. As espécies de microrganismos probióticos mais utilizados são Lactobacillus acidophilus, Lactobacillus casei, Bifidobacterium latis, Bifidobacterium bifidum e Saccharomyces boulardii.

Pesquisas recentes têm demonstrado o potencial de algumas destas espécies no tratamento e prevenção da mastite bovina tendo em vista sua atividade inibitória sobre os patógenos responsáveis por esta infecção, através de mecanismos como a exclusão competitiva, a produção de ácidos orgânicos, peróxido de hidrogênio e bacteriocinas e a capacidade de modular a resposta inflamatória e antiinflamatória inata do hospedeiro.

As preparações contendo espécies de microrganismos probióticos devem apresentar características mínimas de qualidade, como conter os microrganismos vivos e especificados por gênero e cepa, manter a concentração de células adequada ao tratamento durante o prazo de validade do produto e ter mínima variação desta concentração entre diferentes lotes.

Uma das formas de apresentação da preparação probiótica para aplicação intramamária é a emulsão, que consiste de uma mistura de líquidos imiscíveis na presença de um agente emulsificante. A escolha dos componentes desta emulsão deve ser criteriosa, baseada na compatibilidade com o tecido intramamário e na estabilidade conferida à emulsão desenvolvida.

Para a determinação da vida útil desta emulsão probiótica, segundo a Instrução Normativa $\mathrm{n}^{\circ} 15$ do MAPA, deve-se avaliar sua estabilidade através de um estudo de estabilidade acelerado para a determinação do prazo de validade provisório e posteriormente através de um estudo de estabilidade de longa duração para a determinação do prazo de validade real do produto.

Diante do exposto, o presente trabalho teve como objetivo contribuir para o desenvolvimento de técnicas alternativas para prevenção e tratamento de mastite bovina. Especificamente, foram avaliadas diferentes formulações de emulsões base, bem como de agentes conservantes, com o objetivo de formular e avaliar as características físicoquímicas e microbiológicas de preparações contendo cepas de Lactobacillus. 


\section{REVISÃO DE LITERATURA}

\subsection{Pecuária leiteira no Brasil}

De acordo com a Empresa Brasileira de Pesquisa Agropecuária (EMBRAPA), o Brasil é responsável por $5 \%$ da produção mundial de leite, o que o coloca como o quinto maior produtor no mundo (BRASIL, 2012). Segundo o Instituto Brasileiro de Geografia e Estatística (IBGE) (2015), a região sudeste possui o maior rebanho e a maior produção, com 40,6\% da produção nacional, sendo o estado de Minas Gerais o maior produtor, responsável por 26,2\% do leite consumido no Brasil, seguido pela região Sul e Centro Oeste com $35,0 \%$ e $14,4 \%$, respectivamente. O Nordeste com 4,7\% e o Norte com $5,3 \%$ da produção nacional, completam a lista (IBGE, 2015).

De acordo com dados da ABIA (Associação Brasileira das Indústrias de Alimentos), o setor de laticínios faturou em 2013 R $\$ 50,1$ bilhões, demonstrando um crescimento expressivo quando comparado com os $\mathrm{R} \$ 29$ bilhões de 2009 e $\mathrm{R} \$ 42,2$ bilhões de 2012 (PIVARO, 2014).

Apesar da produção expressiva, a produtividade leiteira no Brasil é considerada baixa quando comparada com outros países produtores como Arábia Saudita, Israel e Estados Unidos. Esta baixa produtividade pode estar relacionada a vários fatores como baixa qualidade nutricional da alimentação do rebanho, fatores genéticos, mão de obra pouco especializada e também a alta incidência da mastite bovina (AGUILAR, 2012).

A balança comercial de produtos lácteos do Brasil passou por uma grande mudança desde 2008, quando apresentava um superávit com uma expectativa de crescimento contínuo. Dados de 2012 mostram que o país se tornou um importador devido ao grande aumento no consumo interno destes produtos, sendo o leite em pó o produto lácteo mais importado, representando $60 \%$ do total das importações, correspondendo a U\$353,3 milhões (BRASIL, 2012).

Com o objetivo de promover a melhoria da qualidade do leite e aumentar a competitividade dos produtos lácteos produzidos no país, em 1996 foi criado o Plano Nacional de Melhoria da Qualidade do Leite. Este plano teve como meta o reconhecimento e valorização do leite com qualidade superior, por meio do pagamento diferenciado por qualidade e estímulos para a especialização do produtor. Desta forma, procurou-se adequar 
o setor lácteo brasileiro para o mercado mundial e assegurar um padrão de qualidade internacional aos produtos (ALVIM, 2014).

Após a criação deste plano, algumas cooperativas de laticínios implantaram programas de pagamento do leite por qualidade, considerando as provas de redutase, crioscopia, contagem de microrganismos aeróbios mesófilos e contagem de células somáticas (MÜLLER, 2002).

Para normatizar os padrões de qualidade físico-químicos e microbiológicos do leite, o MAPA publicou em 2002 a Instrução Normativa $n^{\circ}$ 51, que define valores máximos de Contagem Padrão em Placa (1 x $\left.10^{5} \mathrm{UFC} / \mathrm{mL}\right)$ e de Contagem de Células Somáticas (4 x $10^{5} \mathrm{CS} / \mathrm{mL}$ ). Esta instrução também determina que os limites de resíduos de antibióticos no leite cru refrigerado devem respeitar os valores presentes no Programa Nacional de Controle de Resíduos do Ministério da Agricultura (BRASIL, 2002b).

Em 2011, o MAPA publicou a Instrução Normativa $n^{\circ}$ 62, que atualiza a Instrução Normativa $\mathrm{n}^{\circ}$ 51, de 2002, e que altera a classificação do leite comercial, retirando do mercado os tipos $\mathrm{B}$ e $\mathrm{C}$, mantendo somente o tipo $\mathrm{A}$, pasteurizado e cru refrigerado. Esta norma alterou os valores máximos para a Contagem de Células Somáticas (CCS), com prazos de adequação diferentes para cada região do país (BRASIL, 2011).

Para se adequarem a esta nova realidade, os produtores de leite aumentaram a o consumo e a procura por novos produtos veterinários com eficácia e segurança comprovadas.

\subsection{Mercado brasileiro de produtos veterinários}

Produtos veterinários são definidos pelo artigo $2^{\circ}$ do Decreto 1662/95 do MAPA da seguinte forma:

Entende-se por produto veterinário toda substância química, biológica, biotecnológica ou preparação manufaturada, cuja administração seja aplicada de forma individual ou coletiva, direta ou misturada com os alimentos, destinada à prevenção, ao diagnóstico, à cura ou ao tratamento das doenças dos animais, incluindo os aditivos, suplementos, melhoradores de produção animal, antissépticos, desinfetantes de uso ambiental ou equipamentos, pesticidas e todos produtos que, utilizados nos animais e/ou no seu habitat, protejam, restaurem ou modifiquem suas funções orgânicas e fisiológicas. Compreendem-se ainda, 
nesta definição os produtos destinados à higiene e ao embelezamento dos animais (BRASIL, 2014).

Segundo o SIDAN, o faturamento do mercado brasileiro de produtos veterinários passou de 2,5 bilhões de reais em 2008 para quase 4 bilhões em 2013. A venda do setor em 2013 foi de 25\% de antiparasitários, 27\% de produtos biológicos, 16\% de antimicrobianos, $5 \%$ de suplementos e $26 \%$ para outros produtos farmacêuticos (SIDAN, 2015). Para suprir este aumento na demanda, a indústria veterinária brasileira investiu em estrutura de produção e desenvolvimento de novos produtos.

De acordo com Capanema et al. (2010), a estrutura da indústria farmacêutica veterinária envolve quatro setores de grande importância: pesquisa e desenvolvimento, produção de insumos, produção de especialidades farmacêuticas e "marketing" e vendas. O mercado de medicamentos veterinários no Brasil é dividido entre dois grandes grupos, um formado por grandes empresas multinacionais, com atuação global e que lideram o processo de inovação e pesquisa, e outro formado por empresas brasileiras de pequeno e médio porte que se caracterizam por serem usuárias das tecnologias desenvolvidas pelo primeiro grupo. Entretanto, devido às diferenças entre o padrão de distribuição das espécies e dos problemas sanitários e nutricionais próprios do país, as indústrias nacionais encontraram espaço para também investir em pesquisa e inovação, desenvolvendo novos produtos direcionados ao mercado interno.

Para regulamentar este mercado, o MAPA criou a Coordenação de Fiscalização de Produtos Veterinários (CPV), que fiscaliza a fabricação, o comércio e o uso de produtos veterinários, além de estabelecer normas, regras e instruções para orientar os laboratórios produtores, veterinários e consumidores. Tanto os produtos veterinários biológicos quanto os farmacêuticos precisam de autorização e registro no MAPA para serem colocados no mercado e comercializados, assim como os laboratórios responsáveis pela sua produção (BRASIL, 2014).

\subsection{Mastite bovina}

Define-se como mastite ou mamite, a reação inflamatória da glândula mamária a agentes microbiológicos, agentes químicos, lesões térmicas ou lesões físicas. Esta resposta 
inflamatória que se desenvolve na glândula mamária, leva a um aumento na concentração de proteínas plasmáticas e do número de células leucocitárias sanguíneas mobilizadas do sangue para o tecido mamário (AIRES, 2010).

De acordo com Perez Neto e Zappa (2011), a mastite é a doença que mais acomete vacas leiteiras adultas, sendo responsável por cerca de $40 \%$ de toda a morbidade e, estatisticamente, 3 entre 10 vacas leiteiras apresentam inflamação clínica das glândulas mamárias, das quais $7 \%$ são descartadas e $1 \%$ morre em decorrência da doença.

Segundo Aguilar (2012), apesar dos vários fatores que podem levar a esta inflamação, a principal causa é a invasão e ação de microrganismos nas glândulas mamárias.

De acordo com Aires (2010), esta invasão de microrganismos patogênicos ocorre na maioria dos casos pelo ducto papilar (canal do teto), e se alojam na cisterna da glândula. Normalmente a infecção ocorre durante a ordenha, através da máquina de ordenha, das mãos do ordenhador ou outros materiais contaminados, podendo também ocorrer quando os animais estão no pasto ou em leitos contaminados, nos intervalos entre as ordenhas. Após a ordenha, o canal do teto mantém-se aberto durante uma a duas horas, o que facilita a penetração dos microrganismos (AIRES, 2010).

Devido à variedade de espécies de microrganismos que podem infectar o úbere, o controle e o tratamento da mastite se tornam muito complicados, o que pode gerar prejuízos econômicos significativos, devido à redução da qualidade do leite, redução na produtividade, descarte do leite contaminado e gastos com serviços veterinários e medicamentos (AGUILAR, 2012; OLIVER; MURINDA, 2012).

Oliver e Murinda (2012) classificam os microrganismos mais comuns na mastite bovina em duas categorias:

- Contagiosos: bactérias que residem primariamente na glândula mamária (QUINN et al., 2005). A contaminação ocorre de animal para animal durante o processo de ordenha. Fazem parte deste grupo Streptococcus agalactiae, Staphylococcus aureus e Mycoplasma spp;

- Ambientais: são encontrados naturalmente no habitat das vacas leiteiras. Estão neste grupo Streptococcus uberis, Streptococcus dysgalactiae, e enterobactérias incluindo Escherichia coli e Klebsiella spp.

De acordo com Almeida (2009), a mastite pode se apresentar de duas formas: a) Clínica, que apresenta mudanças visíveis na aparência do leite, como presença de grumos, fibrina e pus, e a glândula mamária se apresenta com aumento de volume, temperatura e 
rubor; b) Subclínica, caracterizada pela manifestação assintomática, ou seja, sem alterações visíveis no leite e na glândula mamária.

Conforme relatado, a maioria destes microrganismos chega à glândula através do canal do teto, com exceção do Mycoplasma, que invade a glândula mamária através da corrente sanguínea. A infecção por Staphylococcus aureus é a causa mais comum de mastite clínica e subclínica nos rebanhos leiteiros, devido à sua capacidade de colonizar a pele e o canal do teto, o que predispõe à infecção intramamária (QUINN et al., 2005).

A detecção para mastite subclínica é feita recorrendo-se a métodos indiretos, como contagem de células somáticas ou o "California Mastitis Test" (CMT), que quantifica a quantidade de ácido desoxirribonucleico (DNA) proveniente de células nucleadas presentes no leite (AIRES, 2010).

Reis, Silva e Brescia (2003) atribui à mastite subclínica perdas de 10 até $26 \%$ na produção de leite, sendo esta perda proporcional ao grau de intensidade do processo inflamatório, da patogenicidade do agente infeccioso e do estágio de lactação. A doença também leva a uma diminuição na qualidade do leite produzido e da função do parênquima glandular e, apesar do animal não apresentar alterações visíveis na glândula, o leite apresenta uma alta Contagem de Células Somáticas (CCS).

Segundo Quinn et al. (2005), a contagem de células somáticas na glândula mamária lactante não-infectada é menor que $10^{5}$ células $/ \mathrm{mL}$. As células somáticas presentes no leite incluem os leucócitos e células epiteliais provenientes de descamação. As células encontradas no leite bovino saudável são neutrófilos (0-11\%), macrófagos (66$88 \%$ ), linfócitos (10-27\%) e células epiteliais (0-7\%). O leite mastítico apresenta um grande aumento no número de neutrófilos que, devido às alterações na permeabilidade capilar causadas pela doença, migram da corrente sanguínea para o leite (AIRES, 2010).

Para Santos (2010), a Contagem de Células Somáticas é um importante indicador de mastite, principalmente da forma subclínica, e um excelente método de avaliação da higiene e qualidade do leite, que reflete o grau de sanidade do rebanho e por isso é o método mais utilizado para detectar a doença em programas de controle e prevenção da mastite em nível mundial. 


\subsection{Anatomia do úbere bovino}

O úbere bovino está localizado abaixo da parte caudal do abdômen, e é onde estão consolidadas as quatro glândulas mamárias. É dividido em quartos que correspondem a cada glândula e que sustentam uma papila mamária (teto). A pele que reveste o teto é fortemente aderida e sem pêlos, diferente do restante do úbere onde a pele é solta, maleável e fina (DYCE; WENSING; SACK, 2010).

De acordo com Brito e Sales (2007), o úbere de uma vaca leiteira pode produzir e armazenar mais de $20 \mathrm{~kg}$ de leite antes da ordenha. Para dar sustentação a esta estrutura existe um sistema de ligamentos suspensórios laterais e centrais. Os ligamentos centrais (ou medianos) prendem o úbere à parede abdominal e separam os quartos mamários em quartos esquerdos e direitos, conforme representado na Figura 1. Sua elasticidade permite a absorção de choques e acomoda as mudanças de peso e tamanho do úbere durante a lactação.

Figura 1. Sistema de suporte do úbere bovino e separação dos quartos mamários.

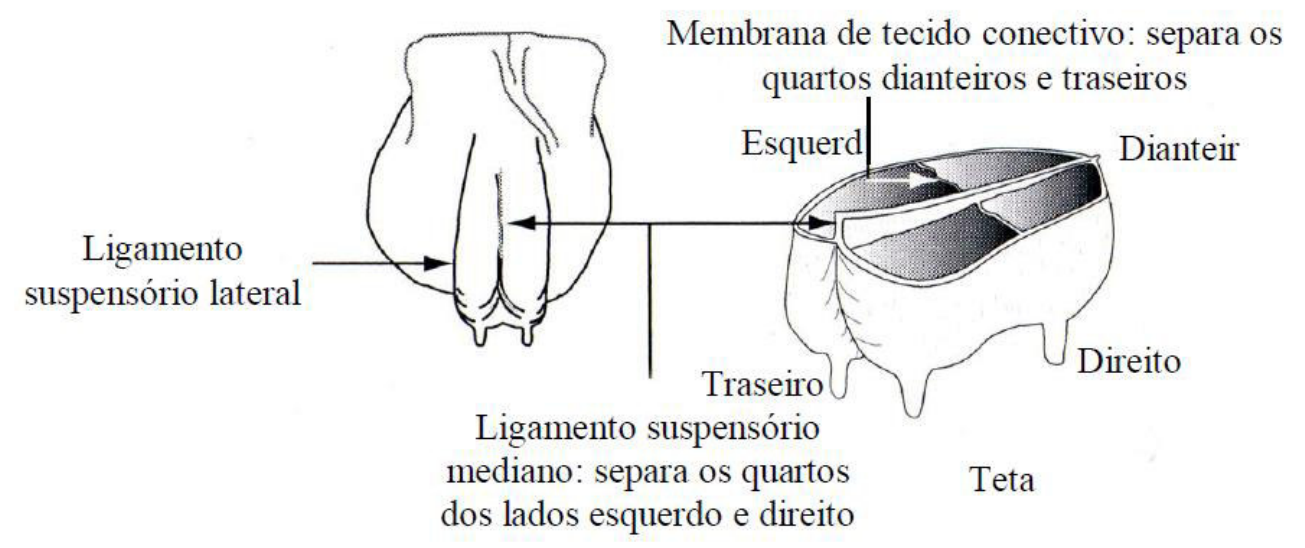

Fonte: BRITO; SALES, 2007.

Cada glândula é envolvida por um sistema de ductos ramificados que se combinam com outros até produzir amplos ductos lactíferos, que se convergem para um grande seio lactífero, com capacidade para centenas de mililitros, na parte ventral do quarto e que se estende para dentro do teto (Figura 2) (DYCE; WENSING; SACK, 2010). 
Figura 2. Glândula mamária, sistema de ductos e teto.

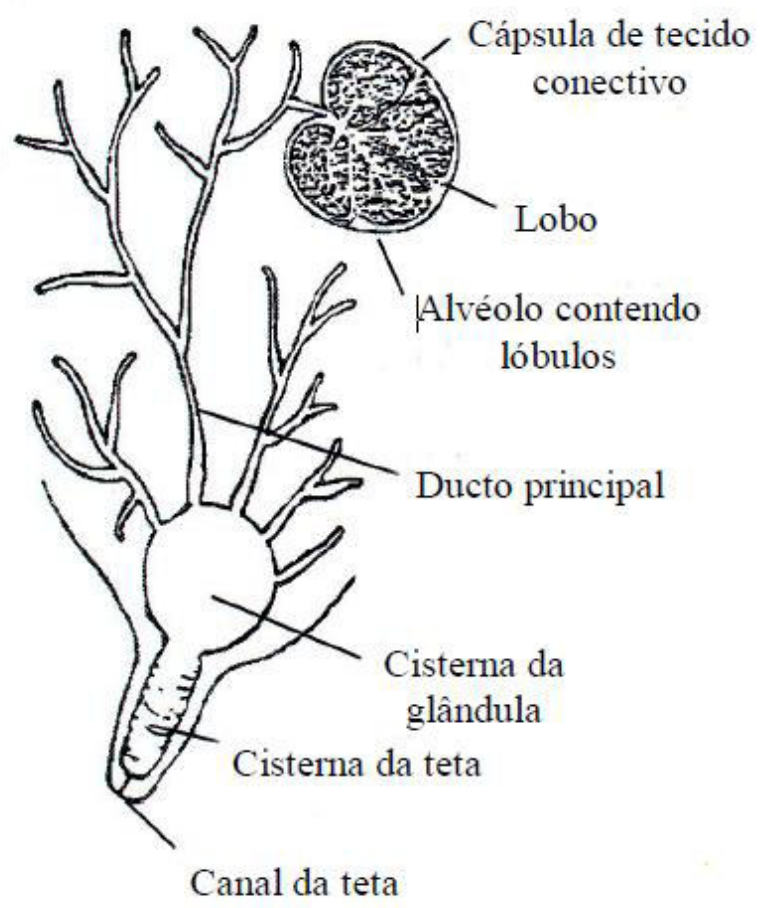

Fonte: BRITO; SALES, 2007.

\subsection{Anatomia do teto (papila mamária)}

Segundo Dyce, Wensing e Sack (2010) os tetos bovinos apresentam na sua maioria a forma cilíndrica, com mais ou menos $8 \mathrm{~cm}$ de comprimento. Sua parede tem uma espessura de cerca de $6 \mathrm{~mm}$, que aumenta para cerca de $7 \mathrm{~mm}$ na parte final onde é atravessada pelo ducto papilar.

O seio lactífero é contínuo com o seio do teto (cavidade do teto), que tem como revestimento uma mucosa formada por um epitélio cubóide estratificado. O limite entre a mucosa do teto e a derme circunjacente da pele é formado por feixes de musculatura lisa paralelos ao eixo longitudinal do teto (DYCE; WENSING; SACK, 2010).

Durante a ordenha, a pele do teto fica esticada e lisa devido ao aumento do fluxo sanguíneo nos vasos da derme. Depois de terminada a ordenha, o sangue é drenado e o músculo liso longitudinal se contrai, voltando a superfície do teto a seu aspecto enrugado típico (EURELL; FRAPPIER, 2012). 
O seio do teto encontra-se normalmente fechado por um anel de músculos circulares (esfíncter) reforçado por tecido elástico (Figura 3) no período entre ordenhas, e está bloqueado por um tampão de queratina proveniente da descamação do epitélio da parede do canal, que impede a entrada e remove microrganismos que tentam invadir o úbere através do orifício do teto (AIRES, 2010; BRITO; SALES, 2007; DYCE; WENSING; SACK, 2010; FARIA, 2015).

Figura 3. Estrutura do teto

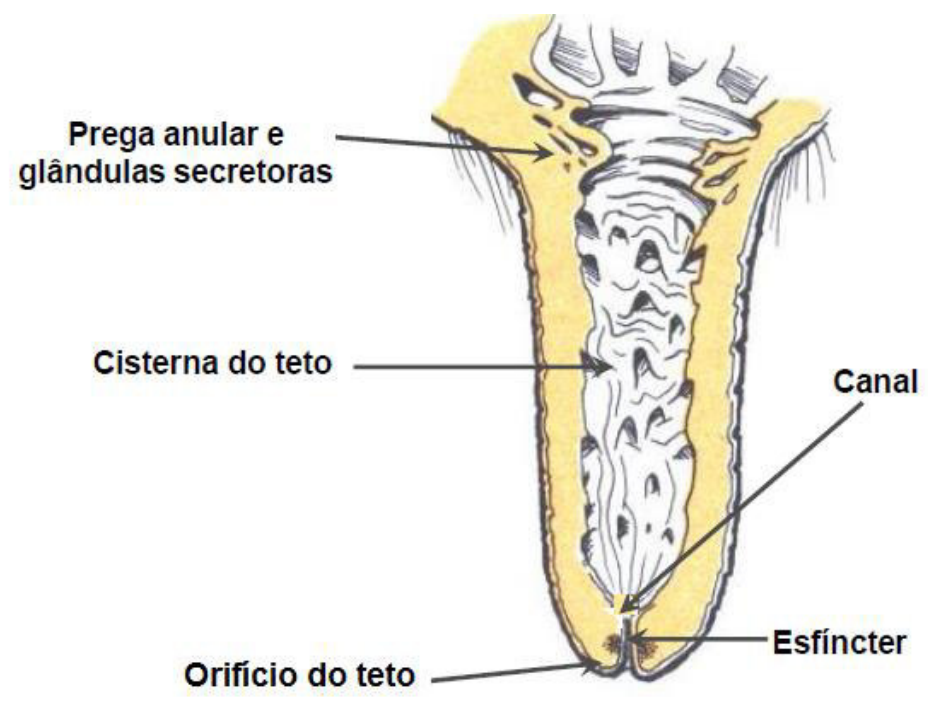

Fonte: FARIA, 2015.

\subsection{Controle e tratamento da mastite bovina}

De acordo com Reis, Silva e Brescia (2003), os programas de controle da mastite bovina não visam sua erradicação, e sim redução na sua prevalência a níveis aceitáveis.

Segundo Müller (2002), um bom programa de controle tem como principais metas erradicar mastites contagiosas causadas por Streptococcus agalactiae e Staphylococcus aureus, manter em níveis baixos as mastites ambientais, manter a contagem de células somáticas abaixo de 200.000 por mililitro de leite, manter em menos de $2 \%$ os episódios clínicos por mês e $85 \%$ das vacas livres de mastite subclínica. 
Algumas medidas simples ajudam no sucesso do programa de controle da mastite, como o monitoramento dos índices de mastite, pré e pós imersão (“dipping”) do teto em soluções antissépticas, conforto ambiental, tratamento das vacas ao secar, tratamento dos casos clínicos, isolamento das vacas com infecções crônicas, higiene, manejo correto e manutenção dos equipamentos de ordenha (MÜLLER, 2002).

Medeiros et al. (2009), avaliaram a sensibilidade in vitro de Staphylococcus ssp isolados de glândulas mamárias com mastite subclínica da região metropolitana de Recife, Agreste e Zona da Mata do estado de Pernambuco, frente aos desinfetantes Cloro (2,5\%), Iodo $(0,57 \%)$, Clorexidine (2,0\%), Amônia quaternária $(4,0 \%)$ e Ácido lático $(2,0 \%)$, comumente utilizados em soluções pré o pós-“dipping” em vacas leiteiras, em quatro tempos de contato diferentes: 15, 30, 60 e 300 segundos.Foi observado que no tempo de 60 segundos $100 \%$ dos Staphylococcus aureus foram sensíveis ao Iodo, 93,3\% a Clorexidine, $80 \%$ a Amônia, 35,6\% ao Ácido lático e 97,8\% foram resistentes ao Cloro. Para Staphylococcus coagulase positiva, $100 \%$ das cepas testadas foram sensíveis ao Iodo e 99,9\% ao Ácido lático, o que demonstra a importância da avaliação periódica dos desinfetantes utilizados nas propriedades leiteiras devido às variações no perfil de sensibilidade e resistência dos microrganismos a estes produtos.

\subsubsection{Tratamento convencional alopático}

O método mais comum disponível para o tratamento da mastite bovina é o uso de infusões intramamárias de antibióticos. A taxa de cura obtida com este tratamento é geralmente baixa e varia de acordo com o tipo de microrganismo (BASKARAN et al., 2009).

Segundo Oliver e Murinda (2012), o úbere bovino é mais susceptível a infecção intramamária durante o período seco (sem lactação), sendo a incidência de novas infecções durante este período seis vezes maior do que a observada durante a lactação. Esta maior susceptibilidade é devido às alterações fisiológicas que a glândula mamária passa para entrar na fase ativa de produção do leite.

O início do período seco é de extrema importância para o controle da mastite em vacas leiteiras. É recomendável que todos os quartos mamários sejam tratados com 
antibióticos aprovados para uso animal após a última ordenha da lactação. Este procedimento tem dois objetivos: evitar infecções adquiridas na fase final da lactação e prevenir novas infecções durante o início do período seco (OLIVER; MURINDA, 2012).

O uso constante de antibióticos no tratamento de doenças infecciosas como a mastite pode levar ao aparecimento de cepas de bactérias resistentes, e a presença de resíduos destes medicamentos no leite produzido pelo animal tratado é outro problema gerado pelo uso de antibiótico (BASKARAN et al., 2009).

Segundo Coelho (2003), o controle e a cura da mastite bovina com antimicrobianos constituem um dos maiores problemas enfrentados pela pecuária leiteira, pois estudos mostram a persistência destes antibióticos, tanto nos quartos tratados quantos nos adjacentes, por períodos maiores que os estabelecidos pelos fabricantes.

Almeida (2009) afirma que a presença destes resíduos gera um problema de saúde pública, pois pode desencadear reações alérgicas em consumidores sensíveis a estas substâncias, além de favorecer o surgimento de cepas resistentes aos respectivos antibióticos. Estes resíduos também podem interferir nos processos de produção e conservação de derivados do leite, pois não são degradados em temperaturas mais altas, persistindo no leite após o tratamento térmico.

Mazurechen (2005) analisou 49 amostras de leite in natura e 140 de leite ultra high temperature (UHT) da região de São José dos Pinhais - PR, pesquisando a presença de antibióticos dos grupos $\beta$-lactâmicos, sulfonamidas, tetraciclinas, aminoglicosídeos e macrolídeos. Das amostras de leite in natura, $18 \%$ apresentaram resíduos de antimicrobianos, enquanto nas amostras de leite UHT somente $1 \%$ foi positivo. Segundo o autor, o fator mais provável pelos resultados positivos é o não cumprimento do período de carência por parte dos produtores, após a aplicação do antimicrobiano, para a comercialização do leite.

Nero et al. (2007) também verificaram a presença de resíduos de antibióticos ( $\beta$ lactâmicos e sulfonamidas) em 210 amostras de leite cru de 4 regiões produtoras de leite no Brasil: Viçosa - MG, Pelotas - RS, Londrina - PR e Botucatu - SP. Foram detectados resíduos em 24 amostras (11,4\%), sendo a maioria (13 amostras) da região de Londrina. Estes resultados sugerem novamente a não observação por parte dos produtores no tocante ao período de carência dos medicamentos.

A Instrução Normativa $n^{\circ} 62$ de 2011 do MAPA exige a pesquisa periódica de resíduos de antibióticos em leite, que não devem ser superiores aos Limites Máximos de Resíduos (LMRs) listados no Codex Alimentarius, conforme estabelecido no Plano 
Nacional de Controle de Resíduos e Contaminantes em Produtos de Origem Animal (PNCRC/Animal). Para tanto, se estabeleceu que ao menos uma análise mensal deve ser realizada, em Unidade Operacional da Rede Brasileira de Laboratórios para Controle da Qualidade do Leite, independentemente da frequência determinada pelo Programa de Controle da Qualidade interno da unidade produtora (BRASIL, 2011).

\subsubsection{Alternativas ao tratamento alopático}

Além do tratamento convencional com a aplicação intramamária de antimicrobianos, existem outras formas alternativas de prevenção e tratamento da mastite. Uma delas é o uso de medicamentos homeopáticos produzidos com substâncias de origem vegetal, animal ou mineral, como também os bioterápicos ou nosódios, que são produzidos a partir de tecidos, secreções, parasitas ou até mesmo de microrganismos (MARTINS et al., 2007).

A homeopatia é uma alternativa aos medicamentos alopáticos, pois apresenta menor custo, facilidade de aplicação e por não haver evidências de gerar resíduos, possibilita que o leite e derivados provenientes de animais tratados desta forma possam ser consumidos sem riscos a saúde e ao ambiente (HONORATO et al., 2006).

Almeida (2009) avaliou o tratamento homeopático com Phytolacca decandra $30 \mathrm{CH}$ durante a lactação de 26 vacas acometidas por mastite subclínica. Após realizar a contagem de células somáticas, análise dos componentes do leite, identificação microbiológica e mensurar a produção leiteira do grupo tratado e controle, não encontrou diferenças significativas nos resultados quando comparados antes e depois do tratamento.

Almeida et al. (2011) avaliou a eficácia de um medicamento bioterápico preparado na potência $12 \mathrm{CH}$ a partir de amostras de leite proveniente de quartos mamários de vacas mastíticas, no tratamento da mastite subclínica bovina causada por Staphylococcus aureus. Foram avaliados 139 quartos mamários de vacas provenientes da região do Sul de Minas Gerais, sendo 69 tratados com o bioterápico e 70 como controle. Após trinta dias de tratamento foram realizadas análises microbiológicas e CMT no leite proveniente de cada quarto mamário dos dois grupos. A eficiência do tratamento foi maior 
no grupo tratado com o bioterápico, permitindo ao autor concluir que a homeopatia se apresentou como uma forma satisfatória de tratamento da mastite subclínica.

Outra alternativa ao tratamento alopático com antibióticos é o uso de medicamentos fitoterápicos, que além de não gerar os problemas relacionados a resistência de bactérias, também representam um menor custo no tratamento e não geram resíduos no leite (MENDONÇA, 2009a).

Gonçalves et al. (2013) avaliaram a atividade antimicrobiana in vitro do óleo essencial de Murta (Blepharocalyx salicifolius) sobre bactérias relacionadas a mastite bovina, utilizando a técnica de microdiluição em caldo. Por meio da determinação da Concentração Inibitória Mínima (CIM) e Concentração Bactericida Mínima (CBM) foi demonstrado que o óleo de Murta apresenta atividade bactericida e bacteriostática sobre os isolados bacterianos provenientes do leite bovino.

Pereira et al. (2009) avaliaram in vitro pelo método de difusão em ágar, a atividade antimicrobiana de extratos vegetais de Mimosa tenuiflora, conhecida popularmente como Jurema-Preta, de Caesalpinia férrea, conhecida como Pau-Preto e de Romã (Punica granatum) sobre Staphylococcus aureus isolado de mastite bovina. Após 48 horas de incubação, foram observados halos de inibição de até $30 \mathrm{~mm}$ de diâmetro, demonstrando a eficácia dos extratos no tratamento da mastite bovina.

Kim et al. (2010) avaliaram a aplicação de lantibióticos no tratamento da mastite. Lantibióticos são peptídeos policíclicos produzidos por bactérias gram-positivas e que apresentam alta atividade antimicrobiana. O estudo avaliou o efeito antimicrobiano do lantibiótico Lacticin NK34 sobre diferentes cepas de Staphylococcus aureus e Staphylococcus coagulase negativo isolados de leite cru de vacas acometidas por mastite subclínica. O Lacticin NK34 apresentou atividade sobre 70\% das cepas de Staphylococcus aureus e $90 \%$ dos Staphylococcus coagulase negativo, demonstrando ser uma substância extremamente útil no tratamento e controle da mastite bovina.

\subsection{Probióticos}

Outra alternativa ao uso de compostos antimicrobianos é o emprego de espécies de microrganismos que apresentam propriedades probióticas no controle e prevenção de 
infecções. Espeche et al. (2012) destacam que as bactérias láticas são as mais indicadas para este tratamento, pois fazem parte da microbiota normal do canal do teto.

Probióticos são microrganismos vivos que, quando administrados em dosagens apropriadas, conferem benefício à saúde do hospedeiro. Podem ser incorporados em uma ampla gama de produtos alimentícios e medicamentosos (OMGE, 2008).

O uso de probióticos, na forma de leites fermentados, data de mais de 10.000 anos, sendo um dos mais antigos métodos de conservação de alimentos. No início do século XX, Elie Metchnikoff relacionou o uso de leite fermentado com a maior longevidade de camponeses búlgaros. Em 1917, durante a primeira guerra mundial, Alfred Nissle isolou uma cepa não patogênica de Escherichia coli que utilizou no tratamento de transtornos intestinais alterando ou substituindo a microbiota intestinal. Na década de 30, no Japão, Shirota isolou uma espécie de Lactobacillus que foi utilizado na produção de um leite fermentado que é comercializado até hoje, inclusive no Brasil (MORAIS; JACOB, 2006; OMGE, 2008).

De acordo com Coppola e Turnes (2004), o termo probiótico deriva do grego e significa "pró-vida", sendo o antônimo de antibiótico, que significa "contra a vida". Este termo apareceu pela primeira vez em 1965, quando Lilly e Stillwell definiram como um fator de origem microbiológico que estimula o crescimento de outros organismos (OMGE, 2008).

Segundo Morais e Jacob (2006), a vinculação do termo probiótico a microrganismos vivos data do final da década de 1980, quando Fuller (1989) definiu probiótico como um suplemento alimentar contendo microrganismos vivos utilizado para melhorar o equilíbrio da microbiota intestinal. Em 2002 este conceito foi reafirmado pela Organização de Alimentos e Agricultura das nações Unidas (FAO) e pela Organização Mundial da Saúde (OMS).

Os probióticos estão diretamente relacionados a ações na microbiota intestinal. Preparações probióticas são utilizadas para evitar diarreia causada por antibióticos, tratar doenças inflamatórias do intestino, síndrome do intestino irritável e infecções intestinais. Também são utilizados em alterações da imunidade, infecções vaginais, artrite reumatoide, eczema atópico e complicações hepáticas (OMGE, 2008).

Probióticos também são utilizados como promotores de crescimento, aumentando o ganho de peso, por meio da redução do $\mathrm{pH}$ intraluminal do tubo digestivo, impedindo a 
colonização da mucosa intestinal por bactérias patogênicas e aumentando a resposta imune humoral (ALMEIDA et al., 2013).

De acordo com Redondo (2008), as bactérias ácido láticas (BAL), que representam a maioria dos microrganismos probióticos, apresentam capacidade de sobreviver em $\mathrm{pH}$ relativamente baixo $(3,5)$, capacidade esta que outros grupos microbianos não apresentam. Este autor ressalta ainda que estas bactérias possuem um sistema simultâneo de transporte de ácido lático e prótons para o meio extracelular, que fornece energia e mantém seu $\mathrm{pH}$ interno.

Algumas espécies de lactobacilos estimulam a secreção do polissacarídeo mucina pelas células intestinais, espessando a barreira intestinal, contribuindo para diminuir processos alérgicos e cancerígenos, protegendo também contra infecção. Espécies de Lactobacillus e Bifidubacterium são capazes de promover lise de proteínas com potencial alergênico no trato gastrintestinal, contribuindo para a redução da alergenicidade das proteínas, reduzindo o risco de alergia alimentar (NOGUEIRA; GONÇALVES, 2011).

Segundo Oliveira (2006), espécies de microrganismos que apresentam propriedades probióticas mais utilizadas são os Lactobacillus acidophilus, Lactobacillus casei, Bifidobacterium latis, Bifidobacterium bifidum e Saccharomyces boulardii.

\subsubsection{Mecanismos de ação}

Dentre os diversos mecanismos de ação responsáveis pelo efeito benéfico provocado pelos probióticos, o principal é a exclusão competitiva, ou seja, os microrganismos probióticos se aderem a sítios específicos no epitélio, impedindo desta forma a colonização por espécies patogênicas (OLIVEIRA, 2006).

De acordo com Kotzamanidis et al. (2010), a capacidade de adesão ao epitélio é o critério mais importante na escolha de microrganismos probióticos a ser utilizado na prevenção e tratamento de infecções, e fatores como hidrofobicidade, capacidade de autoagregação, presença de proteínas de superfície e produção de exopolissacarídeos (EPS), também devem ser considerados, pois influenciam diretamente na aderência e na resposta imunológica do hospedeiro. Quanto maior a hidrofobicidade da superfície e a capacidade de autoagregação e coagregação, maior a aderência da bactéria ao epitélio, 
formando barreiras que impedem a colonização por microrganismos patogênicos. Estas propriedades são específicas de cada cepa (REDONDO, 2008; ESPECHE et al., 2012).

Espeche et al. (2012) isolaram 170 cepas de bactérias ácido-láticas de amostras de leite de diferentes fazendas produtoras da região de Córdoba, na Argentina, e avaliaram a hidrofobicidade, produção de substância inibitórias e de exopolissacarídeos (EPS). Entre as cepas isoladas, quatro espécies foram identificadas: Enterococcus hirae (45,0\%), Pediocynyjoccus pentosaceus (35,0\%), Weissella cibaria (17,5\%) e Enterococcus faecium $(2,5 \%)$. Nenhuma cepa isolada apresentou produção de exopolissacarídeos pelo método utilizado, 94,9\% apresentaram baixo grau de hidrofobicidade, 55,6\% produziram peróxido de hidrogênio e nove cepas apresentaram atividade inibitória sobre Streptococcus dysgalactiae, Listeria innocua e Listeria monocytogenes. Segundo os autores, o fato de não encontrar no leite bactérias produtoras de EPS e com alto grau de hidrofobicidade é devido, provavelmente, aos microrganismos com estas características se manterem aderidos no canal do teto durante a ordenha.

Segundo Morais e Jacob (2006), além da competição pelos sítios de adesão, há também a competição por nutrientes. Esta ação é considerada de extrema importância em virtude da disponibilidade de nutrientes representar um fator limitante para o crescimento bacteriano.

A atividade antimicrobiana atribuída aos microrganismos probióticos se deve também à produção de ácidos orgânicos como láctico e acético, peróxido de hidrogênio e bacteriocinas. A redução do $\mathrm{pH}$ causada pelos ácidos produzidos torna o local tratado um meio impróprio para o desenvolvimento de microrganismos patogênicos (OLIVEIRA, 2006).

Segundo Albornoz (2007), bacteriocinas são proteínas ou peptídeos extracelulares com propriedades bactericida ou bacteriostática que não são letais à espécie produtora. São produzidas tanto por espécies de lactobacilos quanto por bifidobactérias. Lactobacillus reuteri produz uma bacteriocina de baixa massa molecular chamada reuterina, Lactobacillus acidophilus produz a Acidophilucin A e Lactobacillus casei produz a Caseicina 80 (MORAIS; JACOB, 2006; ALBORNOZ, 2007).

Coor et al. (2007) demonstraram a produção da bacteriocina Abp 118 por Lactobacillus salivarius UCC118, e sua ação contra a infecção de camundongos pelas cepas de Listeria monocytogenes EGDe e LO28. A ação antimicrobiana de L. salivarius UCC118 e de um mutante estável incapaz de produzir a bacteriocina foram determinadas e 
comparadas. Os camundongos tratados com L. salivarius UCC118 produtor da Abp 118 não foram infectados pela Listeria monocytogenes, enquanto os animais tratados com o mutante apresentaram quadro de infecção por Listeria monocytogenes, confirmando que a bacteriocina é o fator primário de proteção contra este patógeno.

Outro mecanismo de ação dos probióticos é sua ação no sistema imunológico do hospedeiro. De acordo com Kotzamanidis et al. (2010), os probióticos apresentam capacidade de modular a resposta inflamatória e anti-inflamatória inata e de adaptar a resposta imune do hospedeiro. Algumas espécies de Lactobacillus demonstram aumentar a imunidade do hospedeiro exercendo um aumento da atividade fagocítica dos monócitos e das células polimorfonucleares (PMN), e também na produção de Imunoglobulina A (IgA) e citocinas.

\subsubsection{Preparações probióticas}

Segundo Seale e Millar (2013), probióticos não são considerados drogas, portanto não apresentam composição química definida e não podem ser controlados como tal. São organismos vivos, que se reproduzem, sofrem alterações e interagem dinamicamente com o hospedeiro. Estas características podem gerar consequências adversas, o que justifica a necessidade de regulação e controle no seu uso.

A Organização Mundial de Gastroenterologia (OMGE) (2008) estabelece critérios mínimos de qualidade para os produtos probióticos: devem conter os microrganismos vivos e especificados por gênero e cepa; apresentar uma concentração de microrganismos probióticos adequada ao tratamento durante o prazo de validade do produto, apresentar mínima variação de concentração entre diferentes lotes e existência de estudos de eficácia in vivo.

A Agência Nacional de Vigilância Sanitária (ANVISA) publicou em 2002 a Resolução da Diretoria Colegiada (RDC) n² que regulamenta o uso de probióticos no Brasil. Este regulamento não exige uma concentração mínima de microrganismos nos produtos probióticos, mas determina que a contagem de microrganismos viáveis deva constar no rótulo e que mantenha sua ação durante o respectivo prazo de validade (BRASIL, 2002a). 
De acordo com OMGE (2008) a dose terapêutica de probióticos varia enormemente dependendo da espécie, cepa e produto utilizado. Embora a maioria dos produtos disponíveis no mercado contenha uma concentração entre 1 a 10 bilhões de Unidades Formadoras de Colônia (UFC) por dose, alguns demonstram ser eficazes em doses mais baixas, enquanto outros necessitam de doses maiores para exercer sua função. Portanto, a dosagem correta deve estar baseada em estudos que comprovem a relação da dose com o efeito esperado.

Segundo Nogueira e Gonçalves (2011), a dose terapêutica preconizada e sustentada em estudos é de $5 \times 10^{9}$ UFC por dose diária, porém, efeitos terapêuticos foram encontrados em concentrações entre $10^{6}$ a $10^{9}$ UFC por dose diária.

\subsubsection{Probióticos no tratamento e prevenção da mastite}

Nos anos 80, Linn e Mathiesen (1986) pesquisavam uma alternativa ao tratamento convencional da mastite com antibióticos, utilizando bactérias probióticas. Duas espécies de bactérias ácido láticas (BAL), Lactobacillus acidophilus e Lactobacillus casei, incorporados em uma emulsão para aplicação intramamária, foram avaliadas primeiramente em três vacas acometidas por mastite causada por Staphylococcus aureus e Bacillus sp., com aplicação da emulsão nos quartos mamários doentes de 12 em 12 horas, durante 3 dias. Após 72 horas de tratamento, não foram detectadas bactérias patogênicas no leite dos quartos mamários tratados. Em uma segunda etapa, 15 vacas mastíticas foram tratadas com duas aplicações intramamárias da emulsão probiótica durante o primeiro dia do tratamento. Após uma semana, 10 vacas apresentaram redução no número de células somáticas, demonstrando o potencial do tratamento probiótico no controle da mastite bovina.

Soleimani et al. (2010) utilizaram o método de difusão em ágar para avaliar a atividade antagonista de quatro espécies de Lactobacillus (L. acidophilus DSM 20079, L. plantarum ATCC 8014, L. casei ATCC 39392 and L. reuteri ATCC 23272), frente a duas culturas de Staphylococcus aureus, sendo uma isolada de mastite bovina. Todos os quatro lactobacilos apresentaram atividade inibitória sobre as duas cepas de Staphylococcus 
aureus. L. plantarum ATCC 8014 foi a espécie que apresentou a maior atividade, demonstrando ser eficaz no tratamento da mastite bovina.

Frola et al. (2012) investigaram in vitro a capacidade de adesão de Lactobacillus perolens CRL 1724 e Lactobacillus plantarum CRL 1716 nas células do epitélio do canal do teto bovino e a atividade inibitória e de auto-agregação frente a 14 patógenos isolados de leite mastítico. Também foi avaliada in vivo a aplicação intramamária de $10^{6} \mathrm{UFC} / \mathrm{g}$ de Lactobacillus perolens CRL 1724, utilizando como critérios para avaliação os sinais clínicos, aparência do leite, contagem de células somáticas e recuperação da bactéria $L$. perolens no leite. L. perolens CRL 1724 inibiu o desenvolvimento de 10 dos 14 patógenos e apresentou capacidade de auto-agregação com todos, enquanto L. plantarum CRL 1716 inibiu 7 dos 14 patógenos e apresentou capacidade de auto-agregar semelhante ao $L$. plantarum CRL 1716. L. perolens CRL 1724 também apresentou maior capacidade de adesão (75\%) que L. plantarum CRL 1716 (37\%). No teste in vivo, L. perolens CRL 1724 foi recuperado no leite de todos os quartos mamários tratados. Os úberes apresentaram aspecto normal e não houve alterações no leite. O número de células somáticas aumentou no primeiro dia do tratamento e diminuiu para níveis normais após o segundo dia, se mantendo baixo até o final do experimento. Com estes resultados, Lactobacillus perolens CRL 1724 demonstrou ser uma alternativa aos antibióticos no tratamento da mastite bovina.

Serna, Valencia e Campos (2011) avaliaram a atividade antimicrobiana de quatro bactérias láticas (Lactobacillus acidophilus, Lactobacillus brevis, Lactobacillus fermentum e Weissella confusa) frente a dois patógenos responsáveis pela mastite bovina (Staphylococcus aureus e Streptococcus agalactiae). A atividade antimicrobiana foi determinada pelo método de difusão em ágar pela medição do diâmetro do halo de inibição formado. Weissella confusa apresentou maior atividade inibitória sobre os dois patógenos, demonstrando a maior ação antimicrobiana entre as bactérias láticas testadas, e, portanto seu potencial no tratamento e prevenção da mastite bovina.

Jiménez et al. (2008) avaliaram a eficácia do tratamento da mastite humana em 20 mulheres acometidas por mastite estafilocócica pela ingestão de Lactobacillus salivarius CECT5713 e Lactobacillus gasseri CECT5714 durante 4 semanas. Após 30 dias a contagem de Staphylococcus aureus no leite do grupo tratado foi inferior ao grupo controle, e os Lactobacillus foram isolados do leite de 6 das 10 mulheres do grupo tratado com o probiótico. Após 14 dias não havia mais sintomas da mastite no grupo tratado enquanto no grupo controle os sintomas persistiram durante todo o estudo. Os resultados 
demonstram que a administração oral de probióticos é eficaz no tratamento da mastite causada por Staphylococcus aureus.

Arroyo et al. (2010) também avaliaram a eficácia do tratamento da mastite humana pela administração oral de Lactobacillus fermentum CECT5716 e Lactobacillus salivarius CECT5713 isolados de leite materno. O tratamento foi avaliado e comparado com a eficácia do tratamento tradicional com antibióticos. Dois grupos foram tratados com os probióticos por três semanas e um terceiro grupo foi tratado somente com antibióticos. Após 21 dias a contagem de bactérias no leite dos dois grupos tratados com probióticos foi inferior ao grupo tratado com antibióticos. As duas espécies de Lactobacillus foram isoladas do leite dos grupos tratados com o probiótico, demonstrando que o tratamento é uma alternativa viável ao uso convencional de antibióticos.

Estes trabalhos confirmam a afirmação de Morais e Jacob (2006) de que os probióticos podem determinar efeitos sistêmicos, ultrapassando os limites do local de sua aplicação.

\subsection{Preparações intramamária}

A via intramamária é a via mais comum para o tratamento da mastite bovina e a preferida pela indústria do leite, pois permite aplicações de pequenas quantidades de agentes antimicrobianos diretamente no local da infecção. Os excipientes utilizados em vacas lactantes são projetados visando uma rápida eliminação da preparação e consequentemente uma redução das restrições de suspensão do uso do leite (SMITH, 1994).

A formulação deve causar mínima irritação à glândula, possuir baixo grau de ligação com o leite e tecidos glandulares, liberar rapidamente a substância ativa, ter baixa persistência e possuir caráter lipossolúvel (FRASER, 2001). Dentre os veículos conhecidos, a emulsão farmacêutica se mostra adequada para este tipo de aplicação. 


\subsection{Emulsões farmacêuticas}

Ferreira e Brandão (2008) definem emulsão como um sistema heterogêneo e termodinamicamente instável, resultante de uma mistura de pelo menos um líquido imiscível disperso em outro líquido na forma de gotículas. Segundo o autor, esta mistura é estabilizada através da ação de um ou mais agentes emulsificantes.

Agentes emulsificantes, ou emulsionantes, são agentes tensoativos que possuem a característica de migrar para a interface das duas fases imiscíveis e reduzir a tensão interfacial entre estas fases (THOMPSON, 2006).

Ainda segundo Thompson (2006), as emulsões são divididas em dois tipos principais:

- Óleo em água (O/A): onde a fase oleosa está dispersa na forma de gotícula na fase aquosa, o que diminui a percepção oleosa do produto, sendo o tipo mais utilizado, tanto para uso interno quanto externo;

- Água em óleo (A/O): onde a fase aquosa está dispersa na forma de gotículas na fase oleosa. São utilizadas principalmente para uso externo quando se fazem necessários uma maior emoliência, lubrificação e proteção do ativo.

O tipo de emulsão é determinado pela solubilidade do agente emulsificante utilizado, quando mais hidrofílico, a emulsão formada será do tipo O/A, e quanto mais lipofílico, a emulsão será do tipo A/O. A escolha do agente emulsificante depende das características e tipo de aplicação do produto desenvolvido, entretanto, as concentrações utilizadas devem ser calculadas através do método do equilíbrio hidrófilo-lipófilo (EHL) (FERREIRA; BRANDÃO, 2008).

\subsubsection{Equilíbrio hidrófilo-lipófilo (EHL)}

De acordo com Thompson (2006), o EHL é um método desenvolvido pra determinar as quantidades e o tipo de agente emulsificante utilizado para gerar uma emulsão estável. É baseado no equilíbrio entre as porções hidrofílicas e lipofílicas dos 
tensoativos, que apresenta valores entre 1 e 20, onde valores baixos lipossolubilidade e valores mais altos indicam hidrossolubilidade.

O valor de EHL necessário para a formação de uma emulsão estável é calculado através da soma dos valores de EHL de todos os componentes oleosos da formulação, multiplicados por suas respectivas concentrações. O resultado deve ser divido pela soma das concentrações destes componentes. Com o valor do EHL da emulsão é possível determinar a proporção dos agentes emulsificantes selecionados para a formulação (LINN; MATHIESEN, 1986).

Uma quantidade em excesso de agentes emulsificantes leva a efeitos indesejáveis como formação de espuma e maior poder irritante. Já uma quantidade insuficiente pode não recobrir completamente a gotículas da fase interna da emulsão, o que leva a uma diminuição da estabilidade da emulsão (FERREIRA; BRANDÃO, 2008).

\subsubsection{Estabilidade das emulsões}

O estudo da estabilidade de produtos fornece informações que indicam o grau de estabilidade relativa de um produto em condições variadas a que possa estar sujeito desde sua fabricação até o término de sua validade, e contribui para orientar o desenvolvimento da formulação, fornecer subsídios para seu aperfeiçoamento e estimar o prazo de validade (BRASIL, 2004).

A perda de estabilidade das emulsões ocorre através de dois eventos principais:

- Cremagem (cremeação) e sedimentação (floculação): é uma separação de fases reversível, onde ocorre uma migração da fase interna da emulsão para a parte superior ou inferior da emulsão, migração esta causada pela diferença de densidade das duas fases e da viscosidade da fase externa. A emulsão pode ser restaurada com uma simples agitação do produto (THOMPSON, 2006).

- Coalescência: é uma separação de fases irreversível, onde ocorre a quebra da barreira formada pelo agente emulsionante e consequentemente a fusão das gotículas da fase interna em gotas maiores até a separação total das fases. Não pode ser restaurada somente com a agitação do produto (THOMPSON, 2006). 
Segundo Thompson (2006), a cremagem e sedimentação podem ser controladas através de uma emulsificação adequada e com o aumento da viscosidade da emulsão, através da adição de agentes espessantes. Como a emulsão que apresenta este tipo de instabilidade pode ser reestabelecida somente com sua agitação, cremagem e sedimentação não são consideradas instabilidades críticas nas avaliações de estabilidade do produto (FERREIRA; BRANDÃO, 2008).

Segundo a Instrução normativa $\mathrm{n}^{\circ} 15$ do MAPA (BRASIL, 2005), a estabilidade dos produtos veterinários deve ser avaliada primeiramente através de um estudo de estabilidade acelerado para a determinação do prazo de validade provisório, e posteriormente deve-se realizar o estudo de estabilidade de longa duração para a determinação do prazo de validade real do produto.

\subsubsection{Estudo de estabilidade acelerada}

A Instrução normativa $\mathrm{n}^{\circ} 15$ do MAPA (BRASIL, 2005) determina que o estudo de estabilidade acelerada é imprescindível para a concessão de prazo de validade provisório para preparações de uso veterinário, enquanto se conclui o estudo de estabilidade de longa duração. Este estudo deve ser conduzido em câmara climatizada a:

$-40^{\circ} \mathrm{C} \pm 2{ }^{\circ} \mathrm{C} / 75 \% \pm 5 \%$ de UR (umidade relativa), por um período de 6 (seis) meses; ou,

$-50^{\circ} \mathrm{C} \pm 2^{\circ} \mathrm{C} / 90 \% \pm 5 \%$ de UR, por um período de 3 (três) meses.

É concedido um prazo de validade provisório de 24 meses ao produto se as substâncias ativas se mantiverem estáveis e os outros parâmetros de qualidade do produto permaneçam dentro das especificações durante todo o período de teste.

A avaliação dos parâmetros de qualidade deve ser realizada com a frequência de $0,1,2,3$ e 6 meses para os testes conduzidos por seis meses, e 0, 1, 2 e 3 meses para os testes conduzidos por três meses. 


\subsubsection{Estudo de estabilidade de longa duração}

De acordo com a Instrução normativa $n^{\circ} 15$ do MAPA (BRASIL, 2005), o teste de estabilidade de longa duração é utilizado para a concessão do prazo de validade definitivo do produto. Deve ser realizado em câmara climatizada, nas seguintes condições:

- Para produtos cuja recomendação seja conservar à temperatura ambiente, o teste deverá ser conduzido, obrigatoriamente, a $30^{\circ} \mathrm{C} \pm 2{ }^{\circ} \mathrm{C} / 65 \% \pm 5 \%$ de UR.

- Para produtos cuja recomendação seja conservar sob refrigeração, conservar congelado e conservar abaixo de $-18^{\circ} \mathrm{C}$, o procedimento é análogo ao descrito para os produtos conservados à temperatura ambiente, com exceção das temperaturas críticas.

A avaliação dos parâmetros de qualidade deve ser realizada com a frequência de $0 ; 3 ; 6 ; 9 ; 12 ; 18$ e 24 meses; e anualmente, após o segundo ano até o prazo de validade declarado.

\subsubsection{Componentes da emulsão}

\subsubsection{Fase Aquosa}

A fase aquosa das emulsões é constituída em sua quase totalidade por água purificada, que deve ser pura do ponto de vista iônico (livre de íons) e microbiológico (livre de microrganismos). Como uma das formas de estabilizar uma emulsão é aumentando sua viscosidade, esta fase por ser espessada como polímeros espessantes hidrossolúveis, como a hidroxietilcelulose e a gelatina (FERREIRA; BRANDÃO, 2008). 


\subsection{Hidroxietilcelulose}

Também conhecido pelos seus nomes comerciais Natrosol ${ }^{\circledR}$ e Cellozise ${ }^{\circledR}$, é um polímero não-iônico hidrossolúvel amplamente utilizado em formulações farmacêuticas e cosméticas como agente doador de viscosidade. É relativamente estável na faixa de pH de 2 a 12, e perde viscosidade quando aquecida, mas que retorna com o resfriamento da preparação (ROWE; SHESKEY; OWEN, 2006).

É uma substância não tóxica e não irritante constante no Guia de Ingredientes inativos do Food and Drug Administration (FDA), considerada como própria para o uso em formulações orais, tópicas e oftálmicas. O gel formado é não oclusivo e facilmente removível com água (FERREIRA; BRANDÃO, 2008).

\subsection{Gelatina}

É uma mistura de frações proteicas resultantes da hidrólise do colágeno animal. É amplamente utilizada em cosméticos, medicamentos e alimentos, com as mais diversas funções, como agente de revestimento, agente suspensor, agente geleificante, a gente emulsionante e doador de viscosidade. É totalmente desprovida de toxicidade e não irritante (ROWE; SHESKEY; OWEN, 2006).

Quando em contato com água, a gelatina intumesce, absorvendo até 10 vezes seu peso em água. Solubiliza em água quente e forma gel quando resfriada a $35-40{ }^{\circ} \mathrm{C}$. É considerado um material não tóxico e não irritante, podendo ser utilizada em formulações orais, tópicas, injetáveis e vaginais (FERREIRA; BRANDÃO, 2008).

\subsubsection{Fase oleosa}

De acordo com Ferreira e Brandão (2008), a fase oleosa da emulsão é constituída por óleos líquidos ou ceras, mais os adjuvantes técnicos lipossolúveis. Dentro da variedade 
de componentes oleosos utilizados, alguns se destacam por apresentarem características compatíveis com a emulsão intramamária desenvolvida por este trabalho.

\subsection{Vaselina sólida}

Mistura semi-sólida de hidrocarbonetos purificados extraídos do petróleo. Utilizada como veículo para pomadas oclusivas (BATISTUZZO; ETO; ITAYA, 2006). A vaselina sólida é amplamente utilizada em formulações farmacêuticas como emoliente para pomadas e em formulações transdérmicas. Também possui aplicação em cosméticos e produtos alimentícios (ROWE; SHESKEY; OWEN, 2006).

De acordo com Ferreira e Brandão (2008), a vaselina sólida é um excipiente inerte e com poucas incompatibilidades, associada a uma baixa incidência de reações de hipersensibilidade. Estudos de aplicação subcutânea e oral em camundongos demonstraram que a vaselina é um componente considerado como atóxico, não irritante e não carcinogênico (ROWE; SHESKEY; OWEN, 2006).

\subsection{Vaselina líquida (óleo mineral)}

Constituinte clássico da fase oleosa de emulsões, é um conjunto de hidrocarbonetos obtidos do petróleo. É oleosa, incolor e transparente (BATISTUZZO; ETO; ITAYA, 2006). Possui excelente ação como emoliente para preparações tópicas, ação lubrificante em formulações oftálmicas e muito utilizada em produtos cosméticos e alimentícios (ROWE; SHESKEY; OWEN, 2006). 


\subsection{Lanolina anidra}

Mistura de ésteres de alcoóis esteroidais e alifáticos com ácidos graxos, extraída da gordura da lã do carneiro, que apresenta características semelhantes ao sebum humano (BATISTUZZO; ETO; ITAYA, 2006).

Pode ser utilizada como veículo hidrofóbico em pomadas e emulsões A/O, e também age como um facilitador de penetração cutânea de ativos. Possui a capacidade de absorver o dobro de seu peso em água, sem separação de fases, produzindo emulsões estáveis (ROWE; SHESKEY; OWEN, 2006).

A lanolina anidra, quando purificada, se torna hipoalergênica, o que a deixa totalmente adequada para a aplicação oral ou em mucosas (VIEIRA, 2013).

\subsection{Monoestearato de glicerila (MEG)}

Composto não-iônico simples, empregado em emulsões A/O e O/A, tanto para uso interno como para externo. Quando associado a um tensoativo aniônico, produz autoemulsões principalmente do tipo O/A (BATISTUZZO; ETO; ITAYA, 2006). Muito utilizado como estabilizante, emoliente e plastificante em preparações cosméticas, farmacêuticas e alimentícias. Também possui aplicação como veículo em formulações de liberação sustentada em formas farmacêuticas sólidas, como comprimidos e supositórios, e em formulações de uso veterinário (ROWE; SHESKEY; OWEN, 2006).

Seu uso em formulações orais ou tópicas, cosméticos e alimentos é considerado como atóxico e não irritante (ROWE; SHESKEY; OWEN, 2006). O Monoestearato de glicerila consta no Guia de Ingredientes Inativos do FDA, com seu uso liberado para preparações orais, tópicas, oftálmicas, óticas, retais, vaginais e (FERREIRA; BRANDÃO, 2008).

$\mathrm{Na}$ sua forma pura possui um EHL de 3,8, mas pode ser combinada com surfactantes aniônicos, se tornando uma cera autoemulsionante com o EHL mais elevado, em torno de 5,5 (FERREIRA; BRANDÃO, 2008). 


\subsubsection{5 Álcool cetoestearílico}

Segundo Ferreira e Brandão (2008), o álcool cetoestearílico é um álcool graxo superior, formado pela mistura de dois alcoóis alifáticos sólidos, o álcool estearílico e o álcool cetílico.

Utilizado como espessante em emulsões do tipo O/A. Possui propriedade emoliente sem tornar o veículo muito oleoso (BATISTUZZO; ETO; ITAYA, 2006). É um produto atóxico, também é utilizado como co-emulsificante e estabilizador de emulsões (ROWE; SHESKEY; OWEN, 2006).

\subsubsection{Agentes emulsificantes}

Segundo Ferreira e Brandão (2008), os agentes emulsificantes são compostos que reduzem a tensão superficial entre a fase aquosa e a oleosa, retardando a separação das mesmas. Os emulsionante minimizam a tendência a coalescência das gotículas da fase interna dispersas na emulsão. Na maioria das emulsões, eles são representados pelos tensoativos, que são classificados de acordo com a carga elétrica que geram ao solubilizar: aniônicos (carga negativa), catiônicos (carga positiva) e não-iônicos (não geram cargas). Os emulsionantes não-iônicos são muito resistentes a mudanças de $\mathrm{pH}$ e compatíveis com formulações tanto para uso externo como interno.

\subsubsection{Polissorbato 80 (Tween 80 ()}

Seu nome químico é polioxietileno monooleato de sorbitano, um tensoativo hidrofílico que possui ação de agente emulsificante não-iônico na preparação de emulsões O/A estáveis. Também é utilizado como agente solubilizante e molhante em formulações farmacêuticas orais e parenterais, produtos cosméticos e alimentícios. É atóxico e não irritante (ROWE; SHESKEY; OWEN, 2006). 


\subsubsection{Monooleato de sorbitano 80 (Spam 80 ®)}

O Spam $80 ®$ é uma mistura parcial de um éster de sorbitol com ácidos graxos, utilizado em formulações farmacêuticas, cosméticas e alimentícias como um surfactante não-iônico lipofílico. Também é um componente atóxico e não irritante, bem tolerado em aplicações tópicas, orais e injetáveis, e frequentemente usado em combinação com os polissorbatos para a produção de emulsões estáveis (ROWE; SHESKEY; OWEN, 2006).

\subsubsection{Agentes conservantes}

Conservantes, ou preservantes, são substâncias que quando adicionadas em preparações, seja farmacêutica, cosmética ou alimentícia, possui a função de protegê-las contra contaminações por microrganismos (THOMPSON, 2006).

Para ser eficaz, a escolha do conservante deve se basear no espectro de atividade antimicrobiana, no pH da formulação, na compatibilidade com os outros componentes da fórmula, na sua solubilidade e nos fatores relacionados ao procedimento de produção, como por exemplo temperatura (FERREIRA; BRANDÃO, 2008).

\subsubsection{Metilparabeno}

Com o nome comercial de Nipagim ${ }^{\circledR}$, é um agente conservante de preparações cosméticas, farmacêuticas e alimentícias. É efetivo em uma larga faixa de $\mathrm{pH}$ e possui um amplo espectro de ação antifúngica, sendo mais efetivo contra leveduras e bolores, com pouca atividade contra bactérias. Possui melhor ação conservante em pH de 4 a 8 , perdendo poder conservante em pH mais alto (ROWE; SHESKEY; OWEN, 2006).

Sua maior limitação de uso está relacionada na sua pouca hidrossolubilidade, mas apesar de ser um pó hidrofóbico, na sua concentração usual de 0,05 a 0,25\%, se apresenta solúvel em água (THOMPSON, 2006). 


\subsubsection{Sorbato de potássio}

Sorbato de potássio é um conservante com ação antifúngica e antibacteriana, amplamente utilizado em preparações farmacêuticas, alimentícias e cosméticas. Sua concentração de uso é de 0,1 a $0,2 \%$, é muito solúvel em água. Em pHs próximos a 6 ou mais altos, perde toda sua ação antibacteriana, sendo eficaz somente frente aos fungos, enquanto em pHs mais ácidos tem sua ação antibacteriana realçada (ROWE; SHESKEY; OWEN, 2006). 


\section{MATERIAL E MÉTODOS}

Os experimentos de desenvolvimento da formulação e estabilidade físico-química foram realizados nos laboratórios da Pharmatus Farmácia com Manipulação - Itajubá, MG, e os experimentos envolvendo micro-organismos probióticos foram desenvolvidos no Laboratório de Probióticos da Escola de Engenharia de Lorena - EEL - Universidade de São Paulo - USP.

\subsection{Micro-organismos e desenvolvimento da formulação probiótica}

Para o desenvolvimento da preparação probiótica proposta no presente trabalho foram avaliadas 5 cepas de Lactobacillus, a saber: L. acidophilus ATCC 4356, L. casei ATCC 7469, L. fermentum ATCC 9338, L. plantarum ATCC 8014 e L. paracasei Nestlé ST11, na forma de um "pool".

O procedimento foi realizado em etapas conforme demonstrado na Figura 4, sendo que a primeira consistiu no desenvolvimento de uma emulsão estável e adequada para aplicação intra-mamária e incorporação das cepas probióticas. Para garantir maior estabilidade microbiológica e consequentemente um prazo de validade mais longo para esta preparação, foi realizada a seleção de um agente conservante hidrossolúvel com mínima interferência na atividade das bactérias probióticas.

Desta forma, a preparação foi produzida e as cepas probióticas incorporadas em concentração aproximada de $10^{8} \mathrm{UFC} / \mathrm{mL}$, procedendo-se então a avaliação dos parâmetros físico-químicos e microbiológicos, de acordo com a Instrução Normativa $n^{\circ} 15$ do MAPA (BRASIL, 2005) e o Guia de Estabilidade da ANVISA (BRASIL, 2004).

As cepas probióticas avaliadas foram previamente selecionadas considerando sua ação inibitória sobre os patógenos causadores da mastite bovina. 
Figura 4. Fluxograma do desenvolvimento da formulação probiótica.

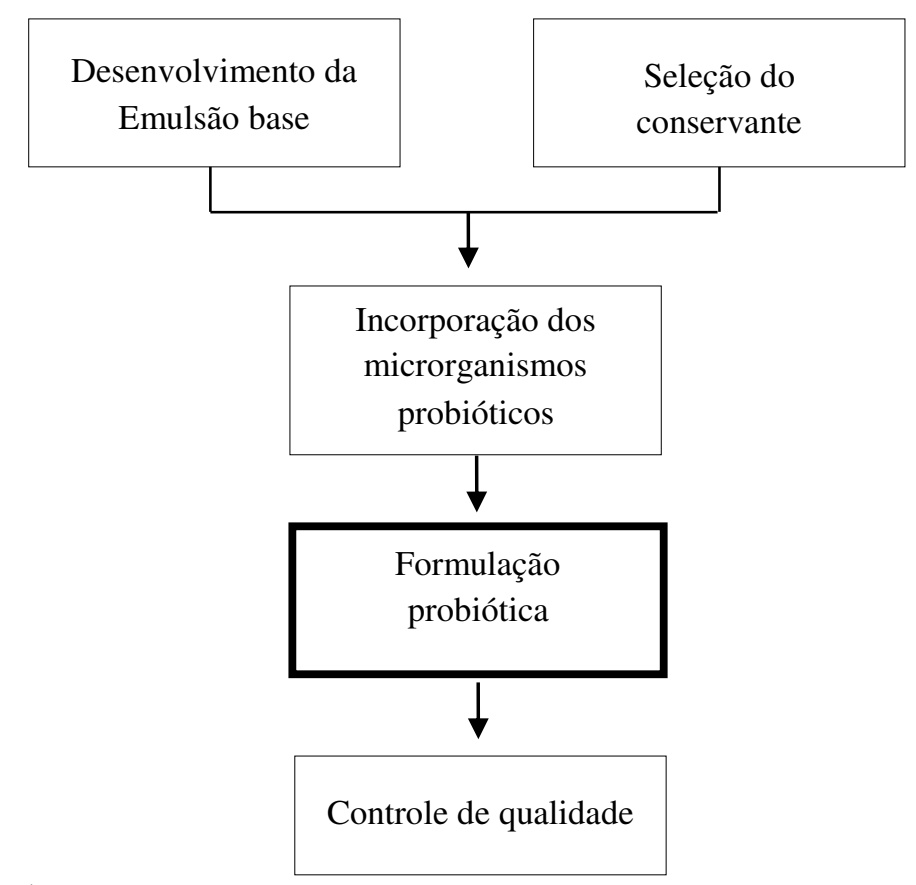

Fonte: do autor.

\subsubsection{Seleção dos componentes da emulsão base}

A formulação probiótica foi desenvolvida na forma de uma emulsão óleo em água (O/A), e foi formulada sustentada no método do Equilíbrio Hidrófilo-Lipófilo (EHL), que se baseia no balanço entre as porções hidrofílicas e lipofílicas das moléculas dos componentes lipossólúveis e no poder emulsificante dos componentes tensoativos. Os valores de EHL dos agentes emulsificantes variam entre 1 e 20, e para se obter uma emulsão estável foram selecionados (Tabela 1) agentes emulsificantes que possuem valor de EHL entre 3 e 6 (lipossolúveis) e 10 e 16 (hidrossolúveis) conforme proposto por Linn e Mathiesen (1986).

Para se calcular o EHL da emulsão, a soma dos valores do EHL de cada componente lipossolúvel multiplicado por sua concentração é dividida pela soma de suas concentrações (FERREIRA; BRANDÃO, 2008). Com o valor do EHL da emulsão, a proporção entre os agentes emulsificantes selecionados foi calculada com base no valor de seu próprio EHL. 
Tabela 1. Agentes emulsificantes avaliados no desenvolvimento da emulsão base e valores de EHL.

\begin{tabular}{l|c|c}
\hline \multicolumn{1}{c|}{ Agentes emulsificantes } & Fornecedor & EHL \\
\hline Polissorbato 80 (Tween $80^{\circledR}$ ) & Labsynth & 15,0 \\
Monoleato de Sorbitano 80 (Spam 80 ${ }^{\circledR}$ ) & Emfal & 4,3 \\
Monoestearato de Glicerila AE (MEG) & Labsynth & 5,5 \\
\hline
\end{tabular}

Sabendo-se que a quantidade interfere no custo da formulação e no seu poder irritante, nos testes preliminares avaliou-se a concentração de $4 \%$ (p/p) de agentes emulsificantes, conforme preconizam Ferreira e Brandão (2008) e Thompson (2006). Entretanto, esta concentração foi alterada durante o desenvolvimento, visando manter a estabilidade da emulsão formulada.

Os componentes da fase oleosa (Tabela 2) foram selecionados baseando-se na compatibilidade biológica com mucosas, poder espessante, capacidade de aderência e custo acessível.

Tabela 2. Componentes oleosos avaliados no desenvolvimento da emulsão base, valores de EHL e concentrações avaliadas.

\begin{tabular}{l|c|c|c}
\hline \multicolumn{1}{c|}{ Componentes oleosos } & Fornecedor & Concentração $(\% \mathrm{p} / \mathrm{p})$ & EHL \\
\hline Vaselina sólida & Labsynth & 10 e 20 & 11,0 \\
Óleo mineral & Labsynth & 5 e 10 & 11,0 \\
Lanolina anidra & Labsynth & 3 & 11,0 \\
Álcool Cetoestearílico & Labsynth & 2 & 15,5 \\
Monoestearato de Glicerila & Labsynth & 8 e 10 & 3,8 \\
\hline
\end{tabular}

A fase aquosa (Tabela 3) foi composta por água destilada acrescida de prebiótico frutoligosacarídeo (FOS) e, quando necessário, os agentes geleificantes hidroxietilcelulose e gelatina hidrolisada foram empregados para ajustar a viscosidade final da emulsão. 
Os conservantes hidrossolúveis metilparabeno e sorbato de potássio foram avaliados como adjuvantes técnicos para auxiliar na manutenção da estabilidade da emulsão. Estes conservantes foram selecionados por meio da metodologia descrita no item 3.1.2.

Tabela 3. Componentes hidrossolúveis utilizados no desenvolvimento da emulsão base e concentrações avaliadas.

\begin{tabular}{l|c|c}
\hline \multicolumn{1}{c|}{ Componentes aquosos } & Fornecedor & Concentração (\% p/p) \\
\hline Hidroxietilcelulose $\left(\right.$ Natrosol $\left.^{\circledR}\right)$ & Pharma Nostra & $0,4,0,8$ e 1,2 \\
Gelatina hidrolisada & Labsynth & 1 \\
Frutoligosacarídeo (FOS) & Pharma Nostra & 2 \\
Metilparabeno (Nipagim $\left.{ }^{\circledR}\right)$ & Pharma Nostra & 0,05 \\
Sorbato de potássio & Labsynth & 0,1 \\
Água destilada & Lab. Probióticos EEL & qsp 100 \\
\hline
\end{tabular}

Legenda: $q s p=$ quantidade suficiente para

\subsubsection{Desenvolvimento e manipulação da emulsão base}

Foram desenvolvidas 12 formulações (Tabela 4), e produzidas em lotes de $100 \mathrm{~g}$, por meio do método de emulsificação por aquecimento sendo o agente emulsificante lipossolúvel adicionado na fase oleosa e o hidrossolúvel adicionado na fase aquosa seguido de aquecimento separado de cada fase.

As formulações foram produzidas em lotes de $100 \mathrm{~g}$, por meio do método de emulsificação por aquecimento sendo o agente emulsificante lipossolúvel adicionado na fase oleosa e o hidrossolúvel adicionado na fase aquosa seguido de aquecimento separado de cada fase. 
Tabela 4. Composição das 12 emulsões base desenvolvidas.

Formulações

\begin{tabular}{lllllllllllllll}
\hline Componentes $(\% \mathrm{p} / \mathrm{p})$ & 1 & 2 & 3 & 4 & 5 & 6 & 7 & 8 & 9 & 10 & 11 & 12 \\
\hline
\end{tabular}

Vaselina sólida

$\begin{array}{lllllllll}20 & 20 & 20 & 20 & 10 & 10 & 20 & 20 & 20\end{array}$

Óleo mineral

$\begin{array}{llllllllllll}10 & 10 & 10 & 10 & 10 & 10 & 10 & 5,0 & 5,0 & 5,0 & 5,0 & 5,0\end{array}$

Lanolina anidra

Álcool Cetoestearílico

Monoestearato

de Glicerila

Tween $80^{\circledR}$

$$
\begin{array}{llllllllllll}
2,5 & 2,5 & 3,8 & 6,3 & 2,5 & 2,5 & 2,6 & 2,6 & 3,9 & 2,0 & 2,3 & 2,0
\end{array}
$$

Spam $80^{\circledR}$

$$
\begin{array}{lllllllllllll}
1,5 & 1,5 & 2,2 & 3,7 & 1,5 & 1,5 & - & - & - & 4,0 & 3,7 & 4,0
\end{array}
$$

Monoestearato de

Glicerila AE (MEG)

Hidroxietilcelulose

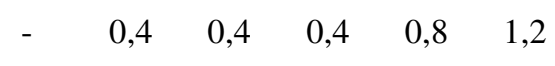

Gelatina

Hidrolisada

Frutoligosacarídeo

(FOS)

$2,0 \quad 2,0 \quad 2,0 \quad 2,0 \quad 2,0 \quad 2,0 \quad 2,0 \quad 2,0 \quad 2,0 \quad 2,0 \quad 2,0 \quad 2,0$

Em um béquer de vidro de 250 mL (Béquer A), pesou-se (Balança mod. BG440, Gehaka) as quantidades predeterminadas dos componentes lipossolúveis acrescida do agente emulsificante lipofílico. Esta mistura foi aquecida até completa fusão dos componentes sólidos.

Em outro béquer de vidro de $250 \mathrm{~mL}$ (Béquer B), pesou-se a quantidade predeterminada do prebiótico FOS, dos agentes espessantes hidroxietilcelulose (Natrosol@) ou gelatina hidrolisada, acrescida da quantidade do agente emulsificante 
hidrofílico. Água destilada foi adicionada em quantidade suficiente para completar $100 \mathrm{~g}$ de emulsão, seguido de aquecimento até $75^{\circ} \mathrm{C}$.

Após aquecimento de ambas as fases, o conteúdo do Béquer B foi vertido sobre o conteúdo do Béquer A e a mistura agitada vigorosamente, utilizando-se um agitador do tipo mixer (mod. Black Plus, Britania) até a formação da emulsão. Em seguida, esta emulsão foi submetida à agitação manual com auxílio de uma espátula plástica até atingir a temperatura ambiente $\left(25,0 \pm 2,0^{\circ} \mathrm{C}\right)$, conforme proposto por Ferreira e Brandão (2008) e demonstrado na Figura 5.

Figura 5. Fluxograma de produção da emulsão base

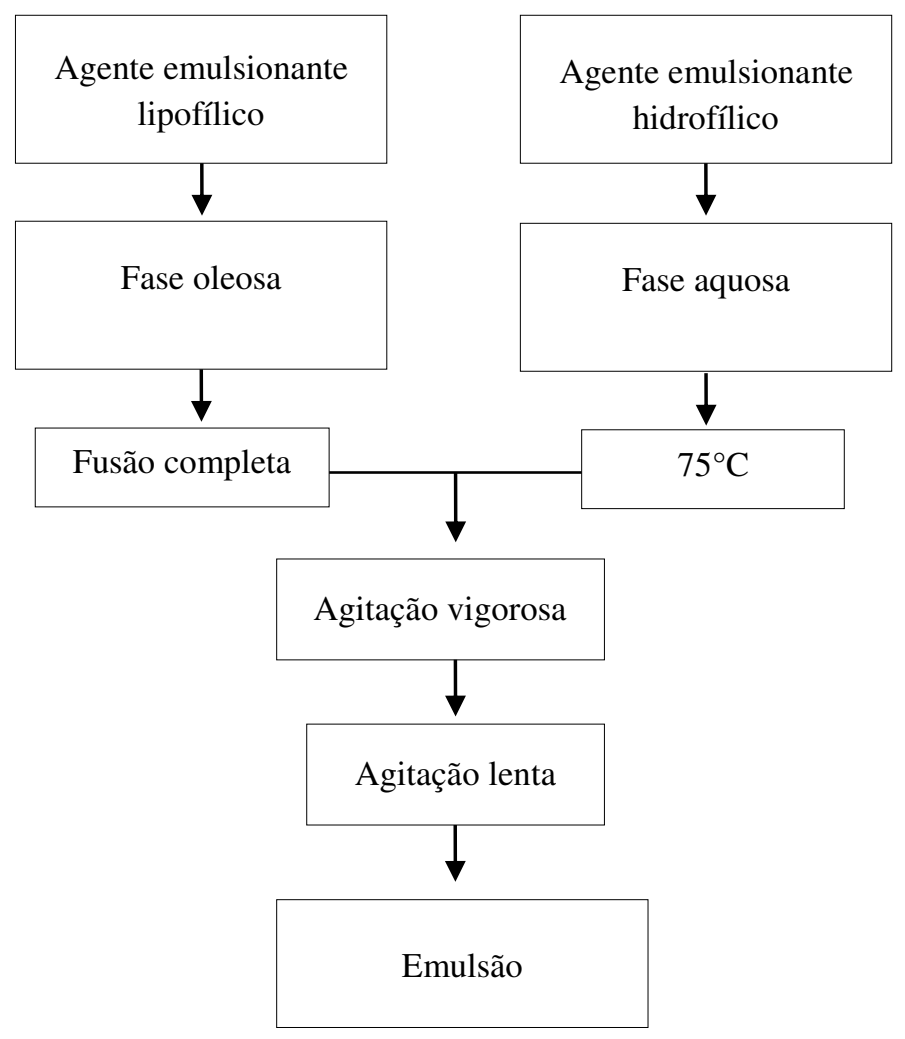

Fonte: do autor

Em seguida, as 12 formulações foram submetidas à avaliação do aspecto macroscópico e de viscosidade cinemática. As formulações que apresentaram sinais de instabilidade com formação de grumos, separação de fases e ausência ou excesso de viscosidade, foram descartadas. As formulações que se apresentaram estáveis foram 
submetidas ao teste preliminar de estabilidade, conforme o proposto pelo Guia de Estabilidade de Produtos Cosméticos da ANVISA (BRASIL, 2004).

\subsubsection{Avaliação preliminar de estabilidade da emulsão}

Para avaliação preliminar da estabilidade das formulações, foram realizados dois testes que consistiram de centrifugação e estresse térmico. Assim, as formulações tiveram seu aspecto macroscópico e viscosidade novamente avaliados, e foram classificadas de acordo com o Guia de Estabilidade de Produtos Cosméticos (Brasil, 2004) em:

- IM: intensamente modificada;

- M: modificada;

- LM: levemente modificada;

- N: normal, sem alteração quanto ao aspecto.

Foram consideradas normais $(\mathrm{N})$ as formulações que não apresentaram separação de fases e levemente modificada (LM) as que apresentaram separação parcial e reversível de fases (cremagem ou sedimentação).

Para se determinar a reversibilidade das fases, a emulsão foi agitada manualmente com auxílio de uma espátula plástica em temperatura ambiente $\left(25,0 \pm 2,0^{\circ} \mathrm{C}\right)$, e uma nova avaliação de homogeneidade foi realizada. Foram consideradas reversíveis as emulsões que retornaram a sua homogeneidade inicial. As formulações que mantiveram a separação de fases (coalescência) foram classificadas como intensamente modificadas (IM) e descartadas.

\subsubsection{Preparo do pool de cepas probióticas}

As culturas probióticas foram ativadas (Figura 6) por repiques sucessivos de culturas estoque das cepas de Lactobacillus incubadas a $37^{\circ} \mathrm{C}$ por $24 \mathrm{~h}$ em tubos de ensaio 
contendo caldo MRS constituído de $10 \mathrm{~g} / \mathrm{L}$ de peptona, $8 \mathrm{~g} / \mathrm{L}$ de extrato de carne, $4 \mathrm{~g} / \mathrm{L}$ de extrato de levedura, $20 \mathrm{~g} / \mathrm{L}$ de glicose, $2 \mathrm{~g} / \mathrm{L}$ de fosfato dipotássico, $5 \mathrm{~g} / \mathrm{L}$ de acetato de sódio trihidratado, $2 \mathrm{~g} / \mathrm{L}$ de citrato triamoniacal, $0,2 \mathrm{~g} / \mathrm{L}$ de sulfato de magnésio heptahidratado, 0,05 g/L de sulfato de manganês tetrahidratado e $1 \mathrm{~mL} / \mathrm{L}$ de Tween 80 , esterilizado em autoclave (mod. EHD, Stermax) a $121^{\circ} \mathrm{C}$ por 15 minutos.

Figura 6. Fluxograma do preparo do pool de Lactobacillus.

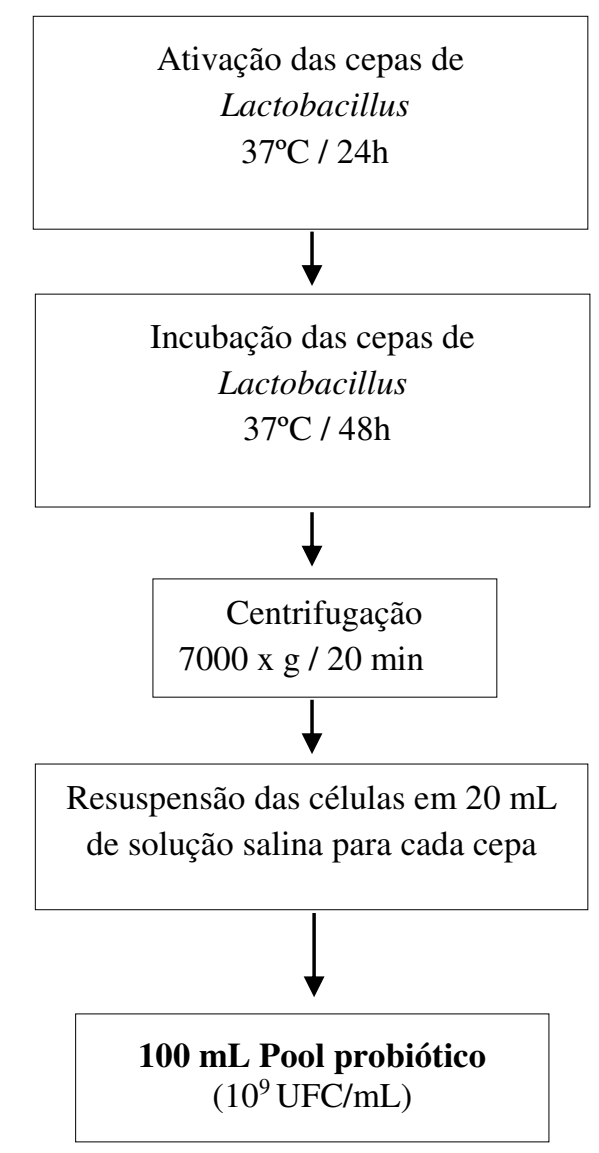

Fonte: do autor

Após a ativação, as cepas foram repicadas em frascos Erlenmeyers contendo 150 $\mathrm{mL}$ de caldo MRS pH 6,2 e incubados (Estufa Spencer Scientific) a $37^{\circ} \mathrm{C}$ por 48 horas. As respectivas suspensões de células foram transferidas para tubos de centrífuga esterilizados $(50 \mathrm{~mL})$ e centrifugadas a $7000 \mathrm{x} g$ por 20 minutos, sendo o sobrenadante descartado e as células sedimentadas ressuspendidas em $20 \mathrm{~mL}$ de solução salina $0,9 \%$ esterilizada. As 
suspensões celulares foram transferidas para um frasco Erlenmeyer de $150 \mathrm{~mL}$ esterilizado para a obtenção do pool de Lactobacillus contendo aproximadamente $10^{9} \mathrm{UFC} / \mathrm{mL}$ de cada cepa.

\subsubsection{Seleção do agente conservante}

Para concluir o desenvolvimento da formulação da emulsão base O/A, avaliou-se a ação de um agente conservante com espectro de ação frente ao desenvolvimento de fungos, visando manter sua integridade dentro do prazo de validade (Figura 6). Foram avaliados dois conservantes hidrossolúveis clássicos com ação antifúngica: metilparabeno e sorbato de potássio nas concentrações $0,05 \%$ e $0,1 \%$, respectivamente. Como resposta, foi avaliado o efeito destes compostos frente ao crescimento das bactérias probióticas.

Para tanto, empregou-se uma técnica adaptada do teste de eficácia antimicrobiana descrito na Farmacopéia Brasileira (2010), que tem como finalidade avaliar a eficácia do conservante sobre o crescimento de microrganismos indesejáveis. No entanto, no presente trabalho este teste teve como objetivo verificar a ausência do efeito inibitório dos respectivos conservantes sobre as espécies que compõem a formulação probiótica, sendo selecionado aquele que apresentou menor efeito inibitório.

Para tanto, soluções aquosas de metilparabeno a $0,5 \%$ e sorbato de potássio a $1 \%$, foram preparadas em béquer de vidro de $50 \mathrm{~mL}$ e aquecidas até $60^{\circ} \mathrm{C}$ para garantir total dissolução em água.

Em seguida $1 \mathrm{~mL}$ da suspensão do pool de Lactobacillus previamente preparado (ver item 3.1.3) foi diluído em 3 tubos de ensaio de $20 \mathrm{~mL}$ contendo $9 \mathrm{~mL}$ do caldo MRS pH 6,2 esterilizado, dos quais foram retiradas alíquotas de $1 \mathrm{~mL}$ para determinação da concentração inicial de células.

Após a amostragem inicial, foi adicionado $1 \mathrm{~mL}$ de solução salina $0,9 \%$ esterilizada no tubo 1 (controle), $1 \mathrm{~mL}$ da solução de metilparabeno $0,5 \%$ no tubo 2 e $1 \mathrm{~mL}$ da solução de sorbato de potássio $1 \%$ no tubo 3 . Os 3 tubos foram incubados em estufa a $37^{\circ} \mathrm{C}$ e foram coletadas amostras nos tempos 7, 14 e 28 dias para determinação da população de células (UFC/mL). Segundo a Farmacopéia Brasileira (2010), o efeito inibitório dos respectivos conservantes é determinado por meio da correlação da população 
de células no tempo inicial e nos respectivos tempos amostragem. Também foi avaliada a variação dos valores de $\mathrm{pH}$.

O conservante que apresentou menor efeito inibitório sobre as bactérias lácticas em estudo foi utilizado na formulação que foi submetida ao teste de estabilidade microbiológica.

Figura 7. Fluxograma do ensaio de seleção do conservante

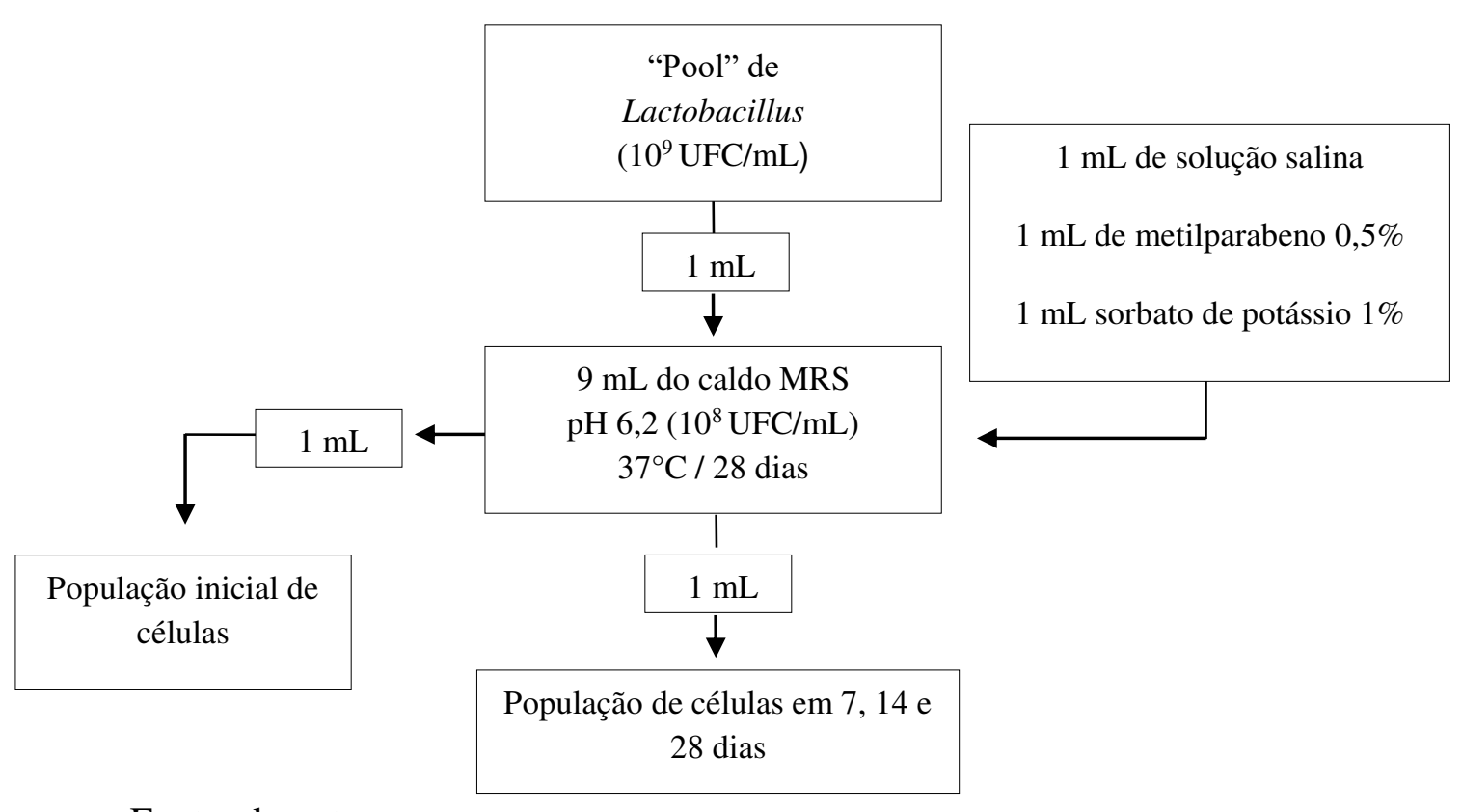

Fonte: do autor

\subsection{Manipulação e avaliação da estabilidade da preparação probiótica}

Após seleção da emulsão base mais estável e do agente conservante, foram manipulados $2000 \mathrm{~g}$ da preparação probiótica, sendo $1000 \mathrm{~g}$ para a realização do teste de estabilidade físico-químico e 1000 g para o teste de estabilidade microbiológica: 


\subsubsection{Manipulação da emulsão base}

Com a formulação da emulsão base definida (Tabela 5), $1800 \mathrm{~g}$ da emulsão foram manipuladas e utilizadas como veículo para as preparações probióticas que tiveram a estabilidade avaliada.

Tabela 5. Formulação da emulsão base

Componentes

Concentração $(\%$ p/p)

Monoestearato de glicerila

Lanolina anidra

Óleo mineral

$\begin{array}{lr}\text { Monoestearato de sorbitano }\left(\operatorname{Spam~} 80^{\circledR}\right) & 3,98\end{array}$

$\begin{array}{lr}\text { Polissorbato } 80 \text { (Tween 80) } & \text { 2,02 }\end{array}$

Frutoligosacarídeo (FOS) 2

Água destilada qsp $1800 \mathrm{~g}$

Desta forma, em um frasco Erlenmeyer de $1000 \mathrm{~mL}$ foram pesados (Balança mod. KN8000DR, Digimed) monoesterato de glicerila, lanolina anidra, óleo mineral e o Spam $80^{\circledR}$, constituindo a fase oleosa da emulsão. Em outro frasco Erlenmeyer de $2000 \mathrm{~mL}$ foram pesados Tween $80^{\circledR}$, prebiótico FOS e água destilada, componentes da fase aquosa da emulsão. O conteúdo dos frascos frascos foi esterilizado em autoclave a $121^{\circ} \mathrm{C}$ por 15 minutos.

As duas fases, devidamente esterilizadas, foram aquecidas até $75^{\circ} \mathrm{C}$ e vertidas em um béquer esterilizado de $4000 \mathrm{~mL}$ em capela de fluxo laminar (mod. 210, Pachane). Esta mistura foi agitada de forma vigorosa, com auxílio de um agitador do tipo mixer esterilizado até a formação de emulsão viscosa e estável, conforme mostrado na Figura 8. Em seguida, a emulsão foi submetida à agitação lenta e manual com auxílio de uma espátula plástica até atingir a temperatura ambiente $\left(25,0 \pm 2,0^{\circ} \mathrm{C}\right) . \mathrm{O} \mathrm{pH}$ final da 
formulação foi ajustado em 5,50 utilizando solução de Ácido cítrico 20\% ou Hidróxido de sódio 1\% (MACEDO et al, 2008).

Figura 8. Fluxograma da produção da emulsão base esterilizada

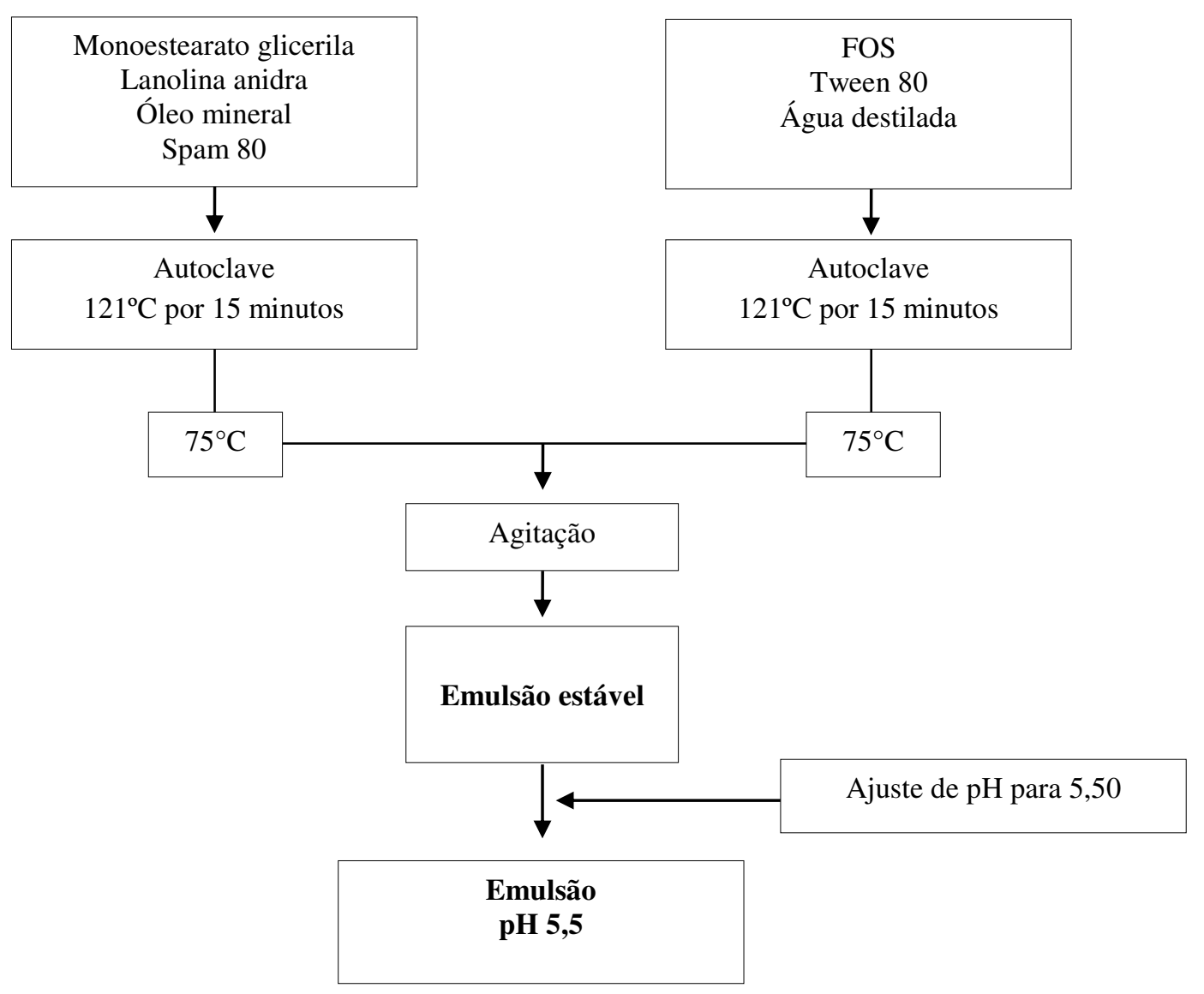

Fonte: do autor

\subsubsection{Manipulação da preparação probiótica e avaliação da estabilidade físico-química}

O estudo de estabilidade acelerada consiste na avaliação da preparação probiótica incubada em estufa por um período de três meses, nas condições de $50^{\circ} \mathrm{C} \pm 2{ }^{\circ} \mathrm{C} / 90 \% \pm$ 5\% de umidade relativa (UR), avaliando seus parâmetros físico-químicos a cada 15 dias.

Para realizar este estudo, foram produzidos $1000 \mathrm{~g}$ da preparação probiótica em capela de fluxo laminar, sendo transferidos para um béquer esterilizado de $2000 \mathrm{~mL}, 900 \mathrm{~g}$ da emulsão base (ver item 3.1.5.1) e 100 mL do "pool" de Lactobacillus (ver item 3.1.3). A mistura foi homogeneizada com o auxílio de um agitador do tipo mixer até mistura completa e homogênea. 
Esta preparação probiótica foi envasada em um frasco Polietileno de boca larga e tampa de rosca com $1200 \mathrm{~mL}$ de capacidade, e então submetida ao estudo de estabilidade acelerada.

O frasco contendo a preparação foi incubado em uma estufa a $50^{\circ} \mathrm{C}$ e $90 \%$ de umidade relativa e amostras foram coletadas no tempo inicial e após 15, 30, 45, 60, 75 e 90 dias para caracterização físico-química mediante avaliação da aparência, homogeneidade, pH, viscosidade e teor da substância ativa (BRASIL, 2005), bem como a densidade da emulsão.

Os critérios adotados para avaliação das amostras no Teste de Estabilidade Acelerada são, segundo o Guia de Estabilidade de Produtos Cosméticos (BRASIL, 2004):

I. Aspecto, cor e odor: as amostras devem manter suas características iniciais, sendo que nos testes realizados em temperaturas elevadas, leves modificações são aceitas;

II. pH: cabe ao formulador determinar a variação e os valores mínimo e máximos, levando em consideração as necessidades e características particulares do produto em teste. Por ser uma preparação biológica, foi definida uma variação máxima de $20 \%$ em relação ao valor inicial.

III. Viscosidade: os limites de aceitação também devem ser definidos pelo formulador. Novamente, por se tratar de uma preparação biológica, foi definido um intervalo de variação mais amplo, com valores de viscosidade cinemática entre 40 e 80 $\mathrm{mm}^{2} / \mathrm{s}$.

IV. Densidade: teste com caráter somente informativo, sem variação máxima definida.

\subsubsection{Manipulação da preparação probiótica e avaliação da estabilidade microbiológica}

A Instrução Normativa $n^{\circ} 15$ de 2005 do MAPA (BRASIL, 2005), define que o principal parâmetro a ser avaliado nos estudos de estabilidade é a variação do teor da substância ativa. Como na preparação desenvolvida no presente trabalho, a substância ativa não se trata de um componente químico, e sim de microrganismos probióticos, foi realizado um estudo de estabilidade de longa duração, o qual forneceu dados suficientes para a determinação do prazo de validade real do produto.

Este estudo consistiu na determinação da estabilidade microbiológica da preparação, realizado através da determinação da viabilidade das cepas de Lactobacillus 
pertencentes ao "pool" probiótico adicionado à formulação. Com o objetivo testar a influência de adjuvantes na estabilidade microbiológica, além da preparação probiótica controle também foram avaliadas preparações contendo: a) agente conservante sorbato de potássio, selecionado no item 3.1.4; b) Sacarose como fonte de carboidrato e c) preparação contendo a associação destes dois adjuvantes.

Para obter as quatro preparações, foram preparados, em frascos Erlenmeyers de $200 \mathrm{~mL}, 100 \mathrm{~mL}$ das soluções dos adjuvantes avaliados: solução de sacarose a 20\%, solução de sorbato de potássio a $1 \%$ e solução de sacarose a $20 \%$ associada ao sorbato de potássio a $1 \%$. As três soluções foram esterilizadas em autoclave a $121^{\circ} \mathrm{C}$ por 15 minutos.

Em capela de fluxo laminar, foram transferidos para um béquer de vidro de 1000 $\mathrm{mL}, 800 \mathrm{~g}$ da emulsão probiótica e $100 \mathrm{~mL}$ do "pool" probiótico. A mistura foi agitada até homogeneidade e dividida em quatro béqueres (A, B, C e D) de $500 \mathrm{~mL}$ (225 g em cada). No béquer A foram adicionados $25 \mathrm{~mL}$ água destilada estéril, no béquer B $25 \mathrm{~mL}$ da solução de Sacarose 20\%, no béquer C $25 \mathrm{~mL}$ da solução de sorbato de potássio $1 \%$ e no béquer D $25 \mathrm{~mL}$ da solução Sacarose $20 \%$ com sorbato de potássio $1 \%$. O conteúdo de cada béquer foi homogeneizado com o auxílio de uma espátula de plástico esterilizada até mistura completa e homogênea.

As respectivas preparações foram envasadas em frascos plásticos esterilizados e armazenadas temperatura ambiente $\left(20^{\circ} \mathrm{C}\right)$ e sob refrigeração $\left(4^{\circ} \mathrm{C}\right)$. A viabilidade das cepas probióticas e o $\mathrm{pH}$ das preparações foram avaliados pelo período de 120 dias, com amostragens realizadas a cada 30 dias.

\subsection{Métodos Analíticos}

\subsubsection{Aparência e homogeneidade}

As preparações foram avaliadas periodicamente quanto às alterações na cor, odor, viscosidade e homogeneidade, tendo como referência o próprio produto recémmanipulado. 
Foram observadas as características físicas das amostras, analisando o produto em um tubo de ensaio de vidro transparente com capacidade de $25 \mathrm{~mL}$, contrastando contra um fundo escuro devido à coloração clara da emulsão e com auxílio de uma fonte de luz, conforme descrito na Farmacopéia Brasileira (2010).

\subsubsection{Teste de centrifugação}

Para o teste de centrifugação foram pesados $10 \mathrm{~g}$ da emulsão em um tubo plástico de centrífuga de capacidade de $50 \mathrm{~mL}$, e centrifugados (Centrífuga modelo BMC, Benfer) a $3.000 \times \mathrm{g}$ durante 30 minutos em temperatura ambiente $\left(25,0 \pm 2,0^{\circ} \mathrm{C}\right)$. Em seguida, as emulsões foram avaliadas contra uma fonte de luz.

\subsubsection{Teste de estresse térmico}

Em um cálice de vidro de $100 \mathrm{~mL}, 50 \mathrm{~g}$ da emulsão foram incubados em estufa (mod. MA 033 , Marconi) a $50^{\circ} \mathrm{C}$ por 24 horas e a $80^{\circ} \mathrm{C}$ por mais 24 horas, para avaliar sua resistência térmica. Após este período e ao atingir a temperatura ambiente $\left(25,0 \pm 2,0^{\circ} \mathrm{C}\right)$, a homogeneidade da emulsão foi avaliada macroscopicamente contra uma fonte de luz.

\subsection{4 pH}

A determinação do $\mathrm{pH}$ da emulsão foi realizado em pHmetro (mod. PG1800, Gehaka) de bancada devidamente calibrado com soluções-estoque padronizadas. A emulsão foi acondicionada em cálice de vidro de $25 \mathrm{~mL}$ em temperatura ambiente $(25,0 \pm$ $\left.2,0^{\circ} \mathrm{C}\right)$ e com o eletrodo introduzido diretamente na emulsão. 


\subsubsection{Densidade}

A densidade foi determinada utilizando-se um picnômetro de $50 \mathrm{~mL}$ previamente calibrado. Esta calibração foi realizada por meio da determinação do peso do picnômetro vazio e seco e seu peso cheio com água destilada a $20^{\circ} \mathrm{C}$.

Após a calibração, foi determinado o peso do picnômetro contendo a preparação em teste, ajustando a temperatura para $20^{\circ} \mathrm{C}$ (FARMACOPÉIA, 2010), sendo a densidade calculada de acordo com a seguinte fórmula:

$$
d=\frac{(m \text { amostra }-m \text { vazio })}{(m \text { água }-m \text { vazio })}
$$

onde: $\mathrm{m}$ amostra $=$ massa do picnômetro cheio com a amostra

$\mathrm{m}$ água $=$ massa do picnômetro cheio com água destilada

$\mathrm{m}$ vazio = massa do picnômetro vazio e seco

$\mathrm{d}=$ densidade

\subsubsection{Viscosidade}

A viscosidade foi avaliada pelo método de viscosidade cinemática, em um viscosímetro (modelo Copo Ford, Gehaka) devidamente calibrado, determinando-se o tempo de escoamento do produto testado por um orifício de diâmetro conhecido.

Devido a sua alta viscosidade, as preparações foram diluídas a 50\% em água destilada em cálice de $125 \mathrm{~mL}$. Foram transferidos $100 \mathrm{~mL}$ para o aparelho e a temperatura ajustada para $25,0 \pm 2,0^{\circ} \mathrm{C}$. Com o auxílio de um cronômetro, o tempo de escoamento da preparação foi medido do início até a primeira falha do escoamento. Para ser considerada como leitura válida, este tempo deve estar entre 20 e 120 segundos.

A viscosidade foi calculada utilizando a equação:

Viscosidade $\left(\mathrm{mm}^{2} / \mathrm{s}\right)=$ CoefA $x \mathrm{t}(\mathrm{s})+$ CoefB,

Onde: $\mathrm{t}=$ tempo de escoamento e CoefA e $\mathrm{B}=$ coeficientes fornecidos pelo fabricante, específicos de cada aparelho. 


\subsubsection{Determinação da população de células viáveis}

Para a determinação da população de células, as amostras foram submetidas a diluições sucessivas de $10^{-1}$ a $10^{-8}$ em solução salina $0,9 \%$ esterilizada, transferindo-se 1 $\mathrm{mL}$ de cada diluição para placas de Petri. Em seguida, adicionou-se $15 \mathrm{~mL}$ de ágar MRS pH 6,2, sendo as placas homogeneizadas por meio de movimentos circulares em forma de oito e deixadas em repouso para a solidificação do Agar, para posteriormente serem invertidas e incubadas a $37^{\circ} \mathrm{C}$ por 72 horas. Em seguida, procedeu-se a contagem das colônias, cujo resultado foi expresso em unidade formadora de colônia por $\mathrm{mL}$ (UFC/mL), considerando-se válidas as placas contendo 30 a 300 UFC. Os ensaios foram realizados em triplicata para a seleção do agente conservante e duplicata no estudo da estabilidade microbiológica

\subsection{Análise estatística dos resultados}

Com a finalidade de elaborar conclusões sobre a estabilidade das preparações, foi utilizada a análise de variância (ANOVA) a fim de encontrar diferenças entre as médias, com um nível de significância de $5 \%$. O teste de Fisher foi utilizado para comparação das médias, quando encontradas diferenças significativas entre os tratamentos. Neste caso, o objetivo foi de verificar eventuais diferenças e assim concluir sobre a estabilidade dos grupos e apontar os grupos discrepantes (ARANGO, 2009). 


\section{RESULTADOS E DISCUSSÃO}

\subsection{Desenvolvimento da emulsão base}

O desenvolvimento da preparação probiótica abrangeu a elaboração de 12 formulações de veículos emulsionados, visando a obtenção de emulsões macroscopicamente estáveis com características apropriadas para a aplicação intramamária. As matérias-primas avaliadas são atóxicas e não irritantes e apresentam compatibilidade com mucosas (ROWE; SHESKEY; OWEN, 2006), o que torna a preparação compatível com o tecido intra-mamário.

As 12 formulações desenvolvidas, mostradas na Tabela 6, foram avaliadas quanto à formação de grumos, separação de fases e viscosidade. Observa-se que seis formulações apresentaram formação grumos quando tiveram sua homogeneidade avaliada. As formulações 2, 3 e 4 apresentaram grumos hidrossolúveis, o que demonstra deficiência na hidratação dos polímeros geleificantes avaliados. Em contrapartida, as formulações 7, 8 e 9 apresentaram grumos lipossolúveis no sobrenadante, o que indica uma emulsificação incompleta, provavelmente causada por deficiência na concentração dos agentes emulsificantes (THOMPSON, 2006).

Observa-se ainda que todas as formulações que apresentaram grumos, hidro ou lipossolúveis, também apresentaram separação irreversível de suas fases, exceto a formulação 1 que apresentou separação de fases irreversível mas sem presença de grumos.

Tanto a formação de grumos quanto a separação de fases indicam a instabilidade da emulsão formada (BRASIL, 2004), sendo, portanto, descartadas.

$\mathrm{Na}$ avaliação da viscosidade, três formulações (1, 6 e 10) foram descartadas por apresentarem viscosidade fora dos padrões predeterminados. 
Tabela 6. Avaliação dos parâmetros físicos das 12 formulações desenvolvidas.

\begin{tabular}{c|c|c|c}
\cline { 2 - 4 } \multicolumn{2}{c}{} & \multicolumn{3}{c}{ Parâmetros } \\
\hline Formulações & Grumos & Separação de fases & Viscosidade $\left(\mathbf{m m}^{2} / \mathbf{s}\right)$ \\
\hline 1 & A & I & 21,35 \\
2 & P & I & 39,44 \\
3 & P & I & 44,53 \\
4 & P & I & 41,01 \\
5 & A & A & 61,51 \\
6 & A & A & 94,24 \\
7 & P & I & 41,01 \\
8 & P & I & 44,53 \\
9 & P & I & 41,01 \\
10 & A & A & 86,59 \\
11 & A & A & 56,50 \\
12 & A & A & 55,60
\end{tabular}

Legenda - Formação de grumos: A (Ausência) e P (Presença)

Separação de fases: A (Ausência), R (Reversível) e I (Irreversível);

Conforme o Guia de Estabilidade de Produtos Cosméticos (2004), foi estabelecido um intervalo de aceitação de viscosidade entre $30 \mathrm{~mm}^{2} / \mathrm{s}$ e $80 \mathrm{~mm}^{2} / \mathrm{s}$. As demais formulações apresentaram valores de viscosidade dentro do intervalo de aceitação.

Desta forma, as formulações 5, 11 e 12 apresentaram características suficientes para serem avaliadas nos ensaios de estabilidade preliminar.

Observa-se que as três formulações selecionadas apresentam um sistema emulsificante contendo Tween $80^{\circledR}$ e Spam $80^{\circledR}$, mas com diferenças na composição da fase oleosa. A formulação 5 é formada por vaselina sólida e óleo mineral e as formulações 11 e 12 são formadas por monoestearato de glicerila, lanolina anidra e óleo mineral. A composição da fase aquosa também apresenta diferenças, sendo a formulação 5 adicionada do polímero geleificante hidroxietilcelulose.

A utilização do polímero geleificante na formulação 5 corrobora com o trabalho de Velasco et al. (2008), que utilizaram os polímeros goma xantana e hidroxipropil guar 
para estabilizar emulsões cosméticas à base de extratos vegetais de Trichilia catigua e Ptychopetalum olacoides. Os autores também avaliaram o uso de ceras auto-emulsionantes (formam emulsões sem necessidade de adição de agentes emulsificantes) na composição da fase oleosa, para aumentar a viscosidade das 14 formulações desenvolvidas. Após avaliação, seis formulações foram rejeitadas por apresentarem separação de fases e viscosidade fora dos padrões determinados.

Lima et al. (2008) avaliaram o uso do polímero acrílico Carbopol® Ultrez a 0,2\% e concluíram que o uso de polímeros geleificantes é uma alternativa eficaz na estabilização dos sistemas emulsionados, devido ao seu mecanismo de estabilização e baixa concentração de uso.

\subsubsection{Avaliação preliminar da estabilidade da emulsão}

As formulações 5, 11 e 12 foram submetidas à avaliação preliminar da estabilidade com a finalidade de selecionar a formulação mais estável. A avaliação preliminar da estabilidade não tem a finalidade de estimar a vida útil do produto, mas de auxiliar na seleção da formulação mais estável (CASTELI et al., 2008).

As três formulações foram submetidas aos testes de resistência à centrifugação (3.000 x $\mathrm{g} / 30 \mathrm{~min})$ e estresse térmico $\left(50^{\circ} \mathrm{C} / 24\right.$ horas mais $80^{\circ} \mathrm{C} / 24$ horas) tendo como resposta as alterações no aspecto macroscópico, separação de fases, formação de grumos e alteração na viscosidade, cujos resultados encontram-se apresentados na Tabela 7.

Observa-se que as três formulações não apresentaram alterações no tocante aos parâmetros estudados, mantendo-se normal (N), após ser submetida ao ensaio de centrifugação. A viscosidade, quando comparada com a viscosidade inicial (Tabela 6), apresentou redução de 5,5\%, 6,8\% e 3,4\% para as formulações 5, 11 e 12, respectivamente.

Após 48 horas de incubação no ensaio de estresse térmico, a formulação 5 foi a que apresentou as maiores alterações no que se refere a formação de grumos e separação de fases. A formulação 11 apresentou separação de fases, que se mostrou irreversível após agitação.

Nota-se que a formulação 12 foi a única que apresentou resultados satisfatórios quando submetidas aos ensaios da estabilidade preliminar sem apresentar alterações nos 
parâmetros avaliados, se mostrando a mais estável, sendo selecionada para formular a preparação probiótica em estudo.

Tabela 7. Parâmetros físicos das formulações 5, 11 e 12 submetidas aos ensaios de centrifugação e estresse térmico da estabilidade preliminar.

\begin{tabular}{|c|c|c|c|c|c|c|}
\hline \multirow[b]{3}{*}{ Parâmetros de estabilidade } & \multicolumn{6}{|c|}{ Formulações } \\
\hline & \multicolumn{3}{|c|}{ Centrifugação } & \multicolumn{3}{|c|}{ Estresse térmico } \\
\hline & 5 & 11 & 12 & 5 & 11 & 12 \\
\hline Presença de grumos & A & A & A & $\mathrm{P}$ & A & A \\
\hline Separação de fases & A & A & A & $\mathrm{P}$ & $\mathrm{P}$ & A \\
\hline Alteração na viscosidade & A & A & A & A & A & A \\
\hline ANVISA & $\mathrm{N}$ & $\mathrm{N}$ & $\mathrm{N}$ & IM & M & $\mathrm{N}$ \\
\hline
\end{tabular}

Avaliação similar foi realizada por Velasco et al. (2008), que submeteram 14 emulsões aos testes de centrifugação e estresse térmico e analisaram a separação de fases e alteração de cor. As formulações que apresentaram separação de fases foram adicionadas de um agente espessante (hidroxipropil guar) e um co-emulsificante (lecitina de soja), entretanto os autores não conseguiram aumentar a estabilidade das emulsões avaliadas.

Segundo Lima et al. (2008) e Rieger (1996), a formulação que foi avaliada como normal após o ensaio de estabilidade preliminar possui maior probabilidade de resistir aos estudos de estabilidade posteriores, pois a força centrífuga e altas temperaturas permite demonstrar a tendência das emulsões em apresentar sinais de instabilidade como a cremagem, sedimentação e a separação total de fases (coalescência). 


\subsection{Seleção do agente conservante}

Com o objetivo de se aumentar a vida útil da preparação probiótica, foram avaliados dois conservantes hidrossolúveis: metilparabeno e sorbato de potássio nas concentrações $0,05 \%$ e $0,1 \%$, respectivamente. Como resposta, foi avaliado o efeito destes compostos sobre a viabilidade das cepas de Lactobacillus contidas na preparação probiótica em estudo, cujos resultados encontram-se apresentados na Tabela 8.

Tabela 8. População de células viáveis e taxa de sobrevivência das bactérias contidas na preparação probiótica na presença de inibidores.

\begin{tabular}{|c|c|c|c|c|c|c|c|}
\hline \multicolumn{8}{|c|}{ População de células viáveis (UFC/mL) e Taxa de sobrevivência (\%) } \\
\hline \multirow{2}{*}{$\frac{\text { Tempo }}{\text { Agente conservante }}$} & \multirow{2}{*}{$\begin{array}{c}\text { Inicial } \\
P_{0}\end{array}$} & \multicolumn{2}{|c|}{7 dias } & \multicolumn{2}{|c|}{14 dias } & \multicolumn{2}{|c|}{28 dias } \\
\hline & & $\mathbf{P}$ & TS & $\mathbf{P}$ & TS & $\mathbf{P}$ & TS \\
\hline Controle & $4,3 \times 10^{8} \mathrm{a}$ & $1,4 \times 10^{9} \mathrm{a}$ & 325,6 & $6,1 \times 10^{7} \mathrm{a}$ & 14,19 & $7,1 \times 10^{7} \mathrm{a}$ & 16,51 \\
\hline Metilparabeno & $6,7 \times 10^{8} \mathrm{~b}$ & $1,1 \times 10^{8} \mathrm{~b}$ & 16,42 & $1,1 \times 10^{7} \mathrm{~b}$ & 1,64 & $3,4 \times 10^{5} \mathrm{~b}$ & 0,05 \\
\hline Sorbato de Potássio & $3,8 \times 10^{8} \mathrm{~b}$ & $1,3 \times 10^{8} \mathrm{~b}$ & 34,21 & $5,5 \times 10^{6} \mathrm{~b}$ & 1,45 & $4,9 \times 10^{5} \mathrm{~b}$ & 0,13 \\
\hline
\end{tabular}

Legenda: P - População de células viáveis (UFC/mL), TS - Taxa de sobrevivência (\%). Média de duas repetições. Médias seguidas da mesma letra na mesma coluna não diferem entre si significativamente ao nível de 5\% de significância pelo teste de Fisher.

Observa-se que tanto no grupo controle, quanto nos grupos contendo os agentes conservantes, houve redução da população de células viáveis. O grupo controle foi o que apresentou a maior taxa de sobrevivência após 28 dias de ensaio, com 16,51\% do número de células viáveis iniciais. Os grupos contendo os agentes conservantes avaliados apresentaram uma redução mais expressiva, com sobrevivência de 0,05\% para o grupo contendo metilparabeno e $0,13 \%$ para o grupo contendo sorbato de potássio. 
Na Figura 9 é possível observar que, as amostras contendo conservantes se comportaram de forma semelhante, com redução da população de células viáveis nos diferentes tempos de amostragens. A população de células viáveis no grupo controle aumentou nos primeiros 7 dias, entretanto apresentou um decréscimo a partir de 14 dias, finalizando em 28 dias de ensaio com 16,51\% da população da células inicial.

Figura 9. Variação da população de células viáveis das cepas contidas na preparação probiótica na presença de diferentes inibidores.

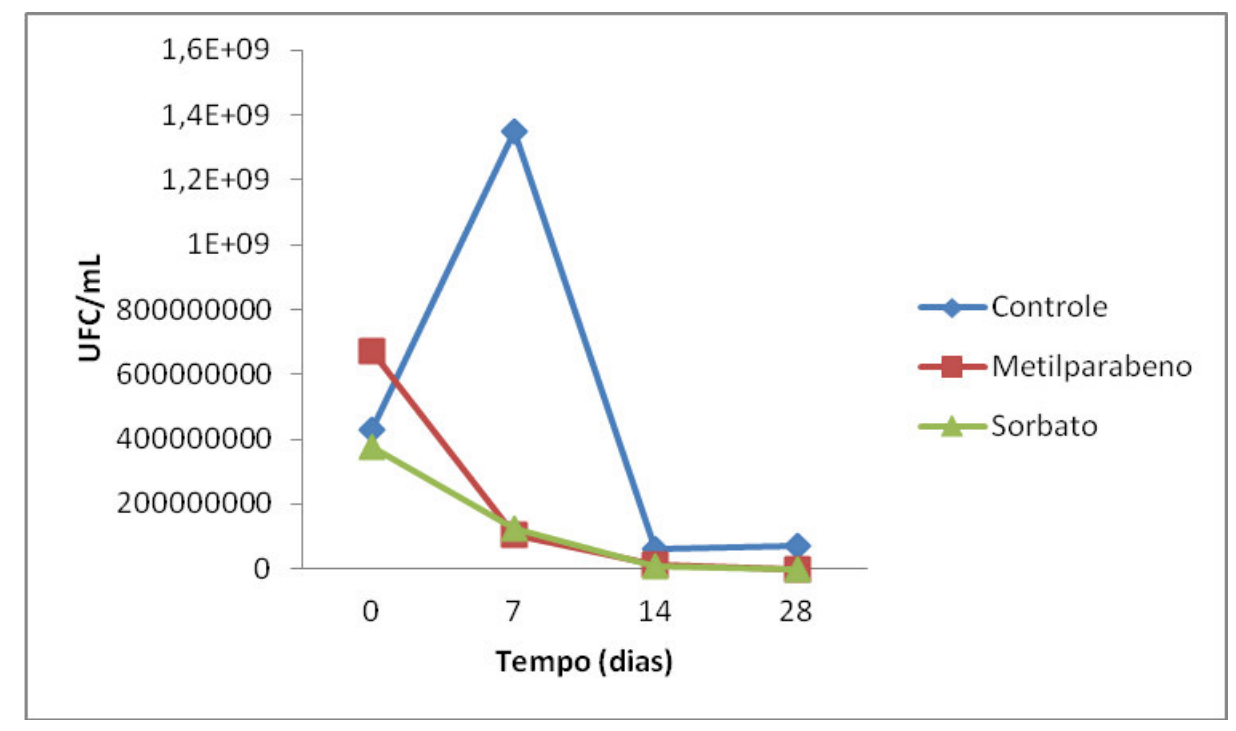

Fonte: do autor

Nota-se que, as populações de células viáveis encontradas nos grupos contendo metilparabeno e sorbato de Potássio são estatisticamente diferentes $(p<0,05)$ em relação ao grupo controle. Este resultado permite afirmar que os agentes conservantes avaliados apresentaram efeito inibitório sobre as cepas de Lactobacillus que compõe a preparação probiótica.

Entretanto, verifica-se que a população de células dos grupos contendo metilparabeno e sorbato de potássio não apresentou redução de três ciclos logarítmicos em relação ao grupo controle nos diferentes tempos de amostragem. De acordo com a Farmacopéia Portuguesa (2005), o conservante eficaz deve apresentar efeito inibitório que reduza três ciclos logarítmicos na população das células em relação ao controle nos primeiros 14 dias do teste, sem que haja aumento desta população microbiana até o final dos 28 dias. 
Os resultados obtidos no presente trabalho diferem dos reportados por Antunes et al. (2009) na avaliação da população de células viáveis de Lactobacillus bulgaricus e Lactobacillus acidophilus em iogurtes contendo $0,03 \%$ de sorbato de potássio armazenados à $10,0 \pm 2,0^{\circ} \mathrm{C}$ por 30 dias. A média da redução na população das bactérias probióticas encontradas pelos autores foi de um ciclo logarítmico $\left(10^{6}\right.$ a $\left.10^{5} \mathrm{UFC} / \mathrm{mL}\right)$, devido provavelmente a menor concentração do agente conservante e a menor temperatura de armazenagem.

Ramos (2010) avaliou o efeito inibitório dos conservantes benzoato de sódio $(0,2 \%$ e $0,4 \%)$, metilparabeno $(0,075 \%$ e $0,15 \%)$ e propilparabeno $(0,025 \%$ e $0,05 \%)$ em formulações líquidas de paracetamol, sulfato ferroso, sulfato de salbutamol e zidovudina sobre o crescimento de Aspergillus niger, Candida albicans, Escherichia coli, Pseudomonas aeruginosa e Staphylococcus aureus. A análise microbiológica mostrou redução média de cinco ciclos logarítmicos na população de todos os microrganismos testados na primeira amostragem (7 dias) para todos os conservantes estudados, com total eliminação de células aos 28 dias de ensaio (RAMOS, 2010).

Quando comparados os resultados entre os conservantes metilparabeno e sorbato de potássio, os mesmos produziram efeitos de inibição estatisticamente semelhantes ao nível de confiança de 95\%. Entretanto, na amostragem final do ensaio, é possível verificar uma população de células viáveis $160 \%$ maior para o grupo sorbato de potássio.

No tocante a variação do $\mathrm{pH}$ nos três grupos, a Tabela 9 mostra os valores encontrados nas diferentes amostragens realizadas nos 28 dias de teste. Verifica-se que nos três grupos houve decréscimo no $\mathrm{pH}$ do meio, sendo que na presença de metilparabeno e sorbato de potássio esta foi mais acentuada.

Observou-se diferenças significativas $(\mathrm{p}<0,05)$ nos valores de $\mathrm{pH}$ na presença de metilparabeno e sorbato de potássio em relação ao controle. Nota-se ainda que não houve diferenças significativas $(\mathrm{p}>0,05)$ no $\mathrm{pH}$ na presença de metilparabeno e sorbato de potássio.

A redução do $\mathrm{pH}$ na presença de sorbato de potássio é similar a encontrada por Antunes et al. (2009), que obteve o pH final 4,15 após 30 dias de armazenamento a 10,0 \pm $2,0^{\circ} \mathrm{C}$ de um iogurte probiótico contendo L. bulgaricus e L. acidophilus. 
Tabela 9. Valores de $\mathrm{pH}$ da preparação probiótica na presença de diferentes agentes inibidores.

\begin{tabular}{l|c|c|c|c}
\hline \multicolumn{1}{c|}{ Tratamento } & Inicial & $\mathbf{7 ~ d i a s}$ & $\mathbf{1 4}$ dias & $\mathbf{2 8}$ dias \\
\hline & $6,83 \mathrm{a}$ & $6,60 \mathrm{a}$ & $6,53 \mathrm{a}$ & $6,42 \mathrm{a}$ \\
Controle & & & & \\
& $6,57 \mathrm{~b}$ & $5,94 \mathrm{~b}$ & $5,01 \mathrm{~b}$ & $4,43 \mathrm{~b}$ \\
Metilparabeno & & & & \\
& & & & \\
Sorbato de potássio & $6,78 \mathrm{~b}$ & $5,95 \mathrm{~b}$ & $4,92 \mathrm{~b}$ & $4,40 \mathrm{~b}$ \\
\hline
\end{tabular}

Médias de duas repetições. Médias seguidas da mesma letra na mesma coluna não diferem entre si significativamente ao nível de 5\% de significância pelo teste de Fisher.

A taxa de sobrevivência observada na presença de sorbato de potássio pode estar relacionada à redução do pH, pois segundo Rowe, Sheskey e Owen (2006), em pH próximo a neutralidade o espectro de ação deste conservante é antifúngico, mas em $\mathrm{pH}$ mais ácido, tem sua ação antibacteriana realçada. Em contrapartida a ação do metilparabeno é independente do pH do meio (ROWE; SHESKEY; OWEN, 2006).

Devido a menor redução no número de células viáveis e a possibilidade de modular seu espectro de ação por meio do ajuste do $\mathrm{pH}$ do meio, o sorbato de potássio foi selecionado para ser avaliado no teste de estabilidade microbiológica da preparação probiótica.

\subsection{Avaliação da estabilidade físico-química da preparação probiótica}

Segundo a Instrução Normativa $n^{\circ} 15$ de 2005, para o pedido de registro de medicamento junto ao MAPA é imprescindível a realização de um estudo de estabilidade físico-química acelerada do produto, com a finalidade de estimar o seu prazo de validade. Este estudo consiste na avaliação da preparação incubada em estufa por um período de três meses, nas condições de $50^{\circ} \mathrm{C} \pm 2^{\circ} \mathrm{C} / 90 \% \pm 5 \%$ de umidade relativa (UR), com amostragens realizadas a cada 15 dias. 
O teste de estabilidade acelerada é considerado um procedimento preditivo, baseado em dados obtidos de produtos armazenados em condições que visam acelerar alterações passíveis de ocorrer nas condições de mercado. Como em todo procedimento preditivo os resultados não são absolutos, mas têm probabilidade de sucesso (VELASCO et al., 2008).

A análise macroscópica das características físicas da emulsão não revelou alterações expressivas da sua estabilidade, tais como alterações de cor, odor e separação de fase.

Na análise realizada após 15 dias a preparação apresentou processo de cremagem, onde a fase oleosa se acumula na superfície da preparação. Este processo foi revertido com agitação manual com espátula plástica. Na última análise, com 90 dias de teste, as preparações se apresentaram mais amareladas e com ressecamento da superfície.

A Tabela 10 mostra média dos resultados dos parâmetros físico-químicos avaliados durante 90 dias, com amostragens realizadas em intervalos de 15 dias.

Foram encontradas diferenças significativas $(\mathrm{p}<0,05)$ nos valores de $\mathrm{pH}$ nos 90 dias de estudo. Por ser uma emulsão biológica com alta concentração de microrganismos viáveis, a redução do pH observada após 30 dias de teste se deve a síntese de ácido lático pelas cepas de Lactobacillus que compõe a preparação probiótica.

Após os 30 dias, o pH se apresentou estável, resultado de uma provável redução do número de células viáveis devido a temperatura elevada do ensaio e pH incompatível com o crescimento das bactérias probióticas.

A redução do $\mathrm{pH}$ da emulsão não é exclusiva para preparações com componentes biológicos ativos. Mendonça et al. (2009b), ao analisarem três emulsões contendo o antifúngico cetoconazol na concentração de $2 \%(\mathrm{p} / \mathrm{p})$, obtiveram somente uma formulação estável em relação ao pH quando submetida ao teste de estabilidade por 90 dias de ensaio, observando valores de $\mathrm{pH}$ dentro do limite de variação aceitável de $10 \%$, definido pelos autores. As outras emulsões apresentaram redução dos valores de $\mathrm{pH}$ fora do limite de aceitação. 
Tabela 10. Variação dos parâmetros físico-químicos da preparação probiótica submetida a $50^{\circ} \mathrm{C} \pm 2^{\circ} \mathrm{C}$ por 90 dias.

\begin{tabular}{|c|c|c|c|c|c|c|c|c|c|}
\hline \multicolumn{10}{|c|}{ Amostragem (dias) } \\
\hline Parâmetro & $\mathbf{0}$ & 15 & 30 & 45 & 60 & 75 & 90 & DP & CV \\
\hline $\mathbf{p H}$ & 4,40 & 3,81 & 3,68 & 3,60 & 3,63 & 3,59 & 3,59 & 0,281 & 0,074921 \\
\hline $\begin{array}{l}\text { Viscosidade } \\
\qquad\left(\mathrm{mm}^{2} / \mathbf{s}\right)\end{array}$ & 65,71 & 36,81 & 36,74 & 45,33 & 46,06 & 48,36 & 71,80 & 15,758 & 0,314438 \\
\hline $\begin{array}{c}\text { Densidade } \\
(\mathrm{g} / \mathrm{mL})\end{array}$ & 0,994 & 0,992 & 0,991 & 0,987 & 0,981 & 0,965 & 0,952 & 0,017 & 0,01741 \\
\hline
\end{tabular}

Legenda: DP - Desvio padrão, CV - Coeficiente de variação. Média de duas repetições.

Em contrapartida, Lima et al. (2008) não encontraram diferenças estatísticas nos resultados da avaliação do pH de uma emulsão contendo óleo de babaçu (Orbignya oleifera) durante os 90 dias de ensaio a $50^{\circ} \mathrm{C}$, demonstrando a estabilidade do $\mathrm{pH}$ na preparação desenvolvida.

No tocante a viscosidade, observa-se diferenças significativas $(\mathrm{p}<0,05)$ nos valores encontrados (Tabela 10) nas amostragens realizadas nos 90 dias de ensaio. Verifica-se a redução da viscosidade nos primeiros 15 dias, seguido de estabilidade no período intermediário de 60 dias e aumento nos 15 dias finais do ensaio.

Resultados similares foram encontrados por Lima et al. (2008) e Velasco et al. (2008), que também verificaram aumento da viscosidade de após 90 dias de teste a $50^{\circ} \mathrm{C}$.

Observa-se que o material do frasco utilizado no ensaio, polietileno, pode ter alterado a viscosidade e densidade da preparação probiótica em estudo, devido a sua porosidade e consequente perda de água pela preparação. Esta observação foi feita por Velasco et al. (2008), que sugerem a adição de um agente umectante como a Glicerina à preparação como alternativa para reduzir ou retardar a perda de água. 
Oliveira (2011) relata que embalagens plásticas com menor permeabilidade aos gases e vapor de água, como o polipropileno e vidro, podem minimizar esta não conformidade.

Mesmo não sendo um parâmetro obrigatório para a avaliação da estabilidade das emulsões, a densidade permite avaliar alterações físico-químicas que podem ocorrer durante o ensaio. Os resultados demonstrados na Tabela 10 mostram uma redução da densidade da preparação, com diferenças significativas $(\mathrm{p}<0,05)$ nos valores obtidos nas diferentes amostragens.

Assim como na viscosidade, a alteração da densidade pode ser causada pela redução da concentração de água na emulsão. A perda de água pela emulsão aumenta a proporção dos componentes lipossolúveis, que apresentam valores de densidade mais baixos que a água, reduzindo a densidade da preparação.

De acordo com o Guia de Estabilidade de Produtos Cosméticos da ANVISA (BRASIL, 2004), os critérios de avaliação dos parâmetros físico-químicos são determinados pelo manipulador, que avalia a influência que eles podem na preparação. Observa-se que dos parâmetros avaliados, somente o pH interfere na estabilidade microbiológica da preparação em estudo e consequentemente reduzir a sua vida útil. Desta forma, sugere-se a utilização de um agente tamponante para manter o pH da entre 5,5 a 6,0.

\subsection{Avaliação da estabilidade microbiológica da preparação probiótica}

A avaliação do teor de princípio ativo é o dado mais importante na determinação da estabilidade de medicamentos. Como o "pool" de bactérias probióticas representa o princípio ativo da preparação desenvolvida no presente trabalho, avaliar a variação na população de células viáveis em relação ao tempo é fundamental para se determinar a vida útil da preparação.

A influência de três fatores na estabilidade da preparação foi: temperatura de armazenamento $\left(4^{\circ} \mathrm{C}\right.$ e a $\left.20^{\circ} \mathrm{C}\right)$, adição do conservante sorbato de potássio $(0,1 \%)$ e a 
adição de uma fonte de carboidrato, representado pela adição de $2 \%$ de sacarose à preparação, o que resultou em um ensaio com oito tratamentos experimentais diferentes.

A Tabela 11 mostra a variação da população das cepas de Lactobacillus submetidas às diferentes condições experimentais durante 120 dias, com amostragens realizadas em intervalos de 30 dias.

Estes resultados foram primeiramente avaliados considerando a ação conjunta da temperatura e presença dos adjuvantes sacarose e sorbato de potássio. Posteriormente, foi avaliado o efeito isolado de cada um destes fatores sobre a população de células viáveis.

$\mathrm{Na}$ análise da influência da temperatura de armazenamento, foram encontradas diferenças significativas $(\mathrm{p}<0,05)$ entre os resultados encontrados para as preparações armazenadas a $4^{\circ} \mathrm{C}$ e as armazenadas em temperatura ambiente, demonstrando a importância da refrigeração na manutenção na viabilidade dos Lactobacillus. As preparações armazenadas em temperatura ambiente apresentaram redução da população em todas as amostragens, com total eliminação de células na preparação adicionada com sorbato de potássio (GTASo) após 120 dias de ensaio.

Na comparação estatística entre os resultados das oito condições experimentais, houve diferença significativa $(\mathrm{p}<0,05)$ entre a preparação adicionada de sacarose armazenada em temperatura ambiente (TASac) e as outras sete condições, demonstrando que esta foi a condição de menor estabilidade do ensaio.

$\mathrm{Na}$ análise dos resultados das preparações mantidas sob refrigeração $\left(4^{\circ} \mathrm{C}\right)$, estatisticamente não foram encontradas diferenças significativas $(p>0,05)$ entre as diferentes condições avaliadas. Entretanto, é possível observar um comportamento diferente (Figura 10) da preparação adicionada com sacarose (RSac) quando comparado com as outras condições. Nota-se que houve aumento na população de células viáveis nos primeiros 30 dias, seguido de redução até o final dos 120 dias do ensaio, onde apresentou redução de meio ciclo logarítmico em relação à população de células inicial, a menor redução entre todas as condições avaliadas. As outras três preparações mantidas a $4^{\circ} \mathrm{C}$ apresentaram maior redução na população de células viáveis, encerrando os 120 dias do ensaio com uma média de redução de dois ciclos logarítmicos.

Verifica-se também que a preparação adicionada de sacarose e mantida a $4^{\circ} \mathrm{C}$ (RSac) manteve sua população de células viáveis em aproximadamente $10^{8} \mathrm{UFC} / \mathrm{mL}$ no final do ensaio, o que permite concluir que, nestas condições, a vida útil (prazo de validade) da preparação probiótica desenvolvida e avaliada no presente trabalho é de, no mínimo, 120 dias. 
Tabela 11. População de células de Lactobacillus submetidas a diferentes tratamentos durante 120 dias de ensaio.

\begin{tabular}{l|c|c|c|c|c}
\hline \multicolumn{1}{c}{ Tratamento } & Inicial & $\mathbf{3 0}$ dias & $\mathbf{6 0}$ dias & 90 dias & 120 dias \\
\hline TA & $8,2 \times 10^{8} \mathrm{a}$ & $1,0 \times 10^{7} \mathrm{a}$ & $3,8 \times 10^{4} \mathrm{a}$ & $5,0 \times 10 \mathrm{a}$ & $1,2 \times 10 \mathrm{a}$ \\
TASo & $9,2 \times 10^{8} \mathrm{a}$ & $2,0 \times 10^{7} \mathrm{a}$ & $1,7 \times 10^{2} \mathrm{a}$ & $3,4 \times 10^{2} \mathrm{a}$ & $0 \mathrm{a}$ \\
TASac & $6,7 \times 10^{8} \mathrm{~b}$ & $5,2 \times 10^{6} \mathrm{~b}$ & $3,5 \times 10^{4} \mathrm{~b}$ & $1,5 \times 10 \mathrm{~b}$ & $0,9 \times 10 \mathrm{~b}$ \\
TASS & $4,9 \times 10^{8} \mathrm{a} \mathrm{c}$ & $1,9 \times 10^{7} \mathrm{a} \mathrm{c}$ & $1,6 \times 10^{4} \mathrm{a} \mathrm{c}$ & $1,4 \times 10 \mathrm{a} \mathrm{c}$ & $0,3 \times 10 \mathrm{a} \mathrm{c}$ \\
R & $8,2 \times 10^{8} \mathrm{a}$ & $3,9 \times 10^{8} \mathrm{a}$ & $6,4 \times 10^{7} \mathrm{a}$ & $4,8 \times 10^{7} \mathrm{a}$ & $5,4 \times 10^{6} \mathrm{a}$ \\
RSo & $9,2 \times 10^{8} \mathrm{a}$ & $5,8 \times 10^{8} \mathrm{a}$ & $3,9 \times 10^{8} \mathrm{a}$ & $7,2 \times 10^{7} \mathrm{a}$ & $3,1 \times 10^{6} \mathrm{a}$ \\
RSac & $6,7 \times 10^{8} \mathrm{ad}$ & $1,4 \times 10^{9} \mathrm{ad}$ & $4,1 \times 10^{8} \mathrm{ad}$ & $2,5 \times 10^{8} \mathrm{ad}$ & $1,9 \times 10^{8} \mathrm{ad}$ \\
RSS & $4,9 \times 10^{8} \mathrm{a}$ & $5,0 \times 10^{8} \mathrm{a}$ & $2,4 \times 10^{8} \mathrm{a}$ & $5,5 \times 10^{7} \mathrm{a}$ & $2,5 \times 10^{6} \mathrm{a}$
\end{tabular}

Legenda: TA - Temperatura ambiente, TASo - Temperatura ambiente + sorbato de potássio, TASac Temperatura ambiente + sacarose, TASS - Temperatura ambiente + sorbato de potássio + sacarose, $\mathrm{R}-$ Refrigeração, RSo - Refrigeração + sorbato de potássio, RSac - Refrigeração + sacarose, RSS Refrigeração + sorbato de potássio + sacarose. Média de duas repetições.

Médias seguidas da mesma letra na mesma coluna não diferem entre si significativamente ao nível de $5 \%$ de significância pelo teste de Fisher.

Em ensaio similar, Antunes et al. (2007) avaliaram a viabilidade de bactérias probióticas (lactobacilos e bifidobactérias) em bebida láctea fermentada e não encontraram diferenças significativas ( $\mathrm{p}>0,05)$ entre grupos adicionados com sacarose e sucralose e os grupos não adicionados após 28 dias de ensaio a $4^{\circ} \mathrm{C}$.

A maior viabilidade das bactérias probióticas encontrada nas condições de refrigeração no presente trabalho está em conformidade com os resultados encontrados por Rodrigues (2011), que avaliou a estabilidade de óvulos (forma farmacêutica de aplicação vaginal) contendo Lactobacillus acidophilus por três meses de armazenamento a $4^{\circ} \mathrm{C}$ e a $20^{\circ} \mathrm{C}$. O autor relatou uma perda progressiva da viabilidade celular, com maior redução nos óvulos armazenados a $20^{\circ} \mathrm{C}$ quando comparados com óvulos armazenados a $4^{\circ} \mathrm{C}$, justificando esta diferença ao fato que a $4^{\circ} \mathrm{C}$ os Lactobacillus estão em estado de latência mais acentuado quando comparado com a temperatura de $20^{\circ} \mathrm{C}$. 
Figura 10. Variação da população de células viáveis nas preparações avaliadas nas diferentes condições sob refrigeração.

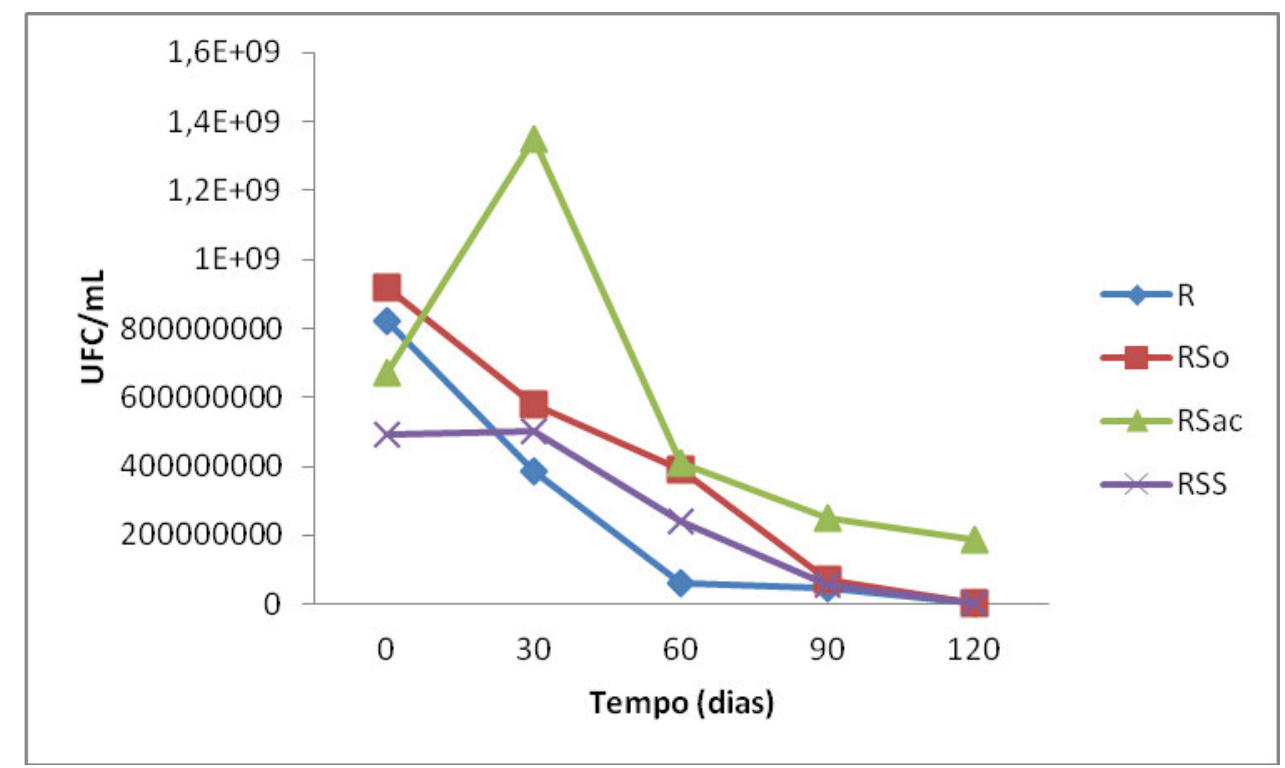

Legenda: R - Refrigeração, RSo - Refrigeração + sorbato de potássio, RSac - Refrigeração + sacarose, RSS - Refrigeração + sorbato de potássio + sacarose. Média de duas repetições. Fonte: do autor.

No mesmo estudo, Rodrigues (2011) também avaliou a variação da população de células viáveis de Lactobacillus acidophilus em óvulos vaginais preparados em diferentes materiais. O autor relatou uma redução expressiva (4 ciclos logarítmicos) nos óvulos preparados com material hidrofílico (polietilenoglicol), enquanto óvulos lipofílicos (glicerídeos semi-sintéticos) apresentaram redução de 2 ciclos logarítmicos após 90 dias a $4^{\circ} \mathrm{C}$, demonstrando maior viabilidade da bactérias probióticas em materiais graxos.

A ativação das cepas probíóticas antes da inoculação também pode interferir na viabilidade das células. Menezes e Drunkler (2014) avaliaram a viabilidade de Lactobacillus acidophilus microencapsulados em maltodextrina, em um ensaio de 30 dias a $18^{\circ} \mathrm{C}$, sendo um grupo com células ativadas (fase estacionária) e outro com células sem ativação. A redução na população de células foi de 0,95 ciclos logaritmos para as culturas ativadas e de 1,44 ciclos para as culturas sem ativação. Não foi observada diferença estatística significativa $(\mathrm{p}>0,05)$ na redução da viabilidade dos grupos, entretanto os autores observaram que culturas ativadas apresentaram maior resistência a estocagem.

De acordo com Rodrigues (2011), a redução na população de células viáveis independente da temperatura de armazenamento pode ser explicada, em partes, pelo impacto do potencial redox no armazenamento da preparação probiótica. A presença de 
oxigênio (potencial redox positivo) nos produtos probióticos pode conduzir a uma diminuição da viabilidade celular. $\mathrm{O}$ autor observa que o armazenamento em condições de atmosfera modificada, como nitrogênio e dióxido de carbono, proporcionaria maior estabilidade da população de células viáveis.

A variação dos valores de $\mathrm{pH}$ nas oito diferentes condições avaliadas no ensaio (Tabela 12) demonstraram redução de $\mathrm{pH}$ em todas as condições com o aumento do tempo.

Novamente a influência da temperatura de armazenamento apresentou diferenças significativas $(\mathrm{p}<0,05)$ nos resultados de $\mathrm{pH}$ encontrados, demonstrando conformidade com os resultados encontrados na avaliação da viabilidade de células.

A preparação armazenada a $4^{\circ} \mathrm{C}$ adicionada com sorbato de potássio (RSo), apresentou diferenças significativas $(\mathrm{p}<0,05)$ em relação a todas as preparações armazenados em temperatura ambiente. Não foi possível evidenciar diferenças significativas $(\mathrm{p}>0,05)$ entre esta preparação (RSo) as demais preparações refrigeradas.

Tabela 12. Variação do pH nos oito tratamentos experimentais durante 120 dias de ensaio.

\begin{tabular}{l|c|c|c|c|c}
\hline Tratamento & Inicial & $\mathbf{3 0}$ dias & 60 dias & 90 dias & 120 dias \\
\hline TA & $4,54 \mathrm{~b}$ & $2,74 \mathrm{~b}$ & $2,56 \mathrm{~b}$ & $2,43 \mathrm{~b}$ & $2,51 \mathrm{~b}$ \\
TASo & $4,39 \mathrm{~b}$ & $2,97 \mathrm{~b}$ & $2,72 \mathrm{~b}$ & $2,58 \mathrm{~b}$ & $2,55 \mathrm{~b}$ \\
TASac & $4,33 \mathrm{~b}$ & $2,68 \mathrm{~b}$ & $2,49 \mathrm{~b}$ & $2,29 \mathrm{~b}$ & $2,34 \mathrm{~b}$ \\
TASS & $4,40 \mathrm{~b}$ & $2,85 \mathrm{~b}$ & $2,61 \mathrm{~b}$ & $2,44 \mathrm{~b}$ & $2,44 \mathrm{~b}$ \\
R & $4,54 \mathrm{a} \mathrm{b}$ & $3,66 \mathrm{a} \mathrm{b}$ & $3,37 \mathrm{a} \mathrm{b}$ & $3,32 \mathrm{a} \mathrm{b}$ & $3,53 \mathrm{a} \mathrm{b}$ \\
RSo & $4,39 \mathrm{a}$ & $3,90 \mathrm{a}$ & $3,77 \mathrm{a}$ & $3,89 \mathrm{a}$ & $3,82 \mathrm{a}$ \\
RSac & $4,33 \mathrm{a} \mathrm{b}$ & $3,58 \mathrm{a} \mathrm{b}$ & $3,27 \mathrm{a} \mathrm{b}$ & $3,11 \mathrm{a} \mathrm{b}$ & $3,08 \mathrm{a} \mathrm{b}$ \\
RSS & $4,41 \mathrm{a} \mathrm{b}$ & $3,82 \mathrm{a} \mathrm{b}$ & $3,57 \mathrm{a} \mathrm{b}$ & $3,29 \mathrm{a} \mathrm{b}$ & $3,25 \mathrm{a} \mathrm{b}$
\end{tabular}

Legenda: TA - Temperatura ambiente, TASo - Temperatura ambiente + sorbato de potássio, TASac Temperatura ambiente + sacarose, TASS - Temperatura ambiente + sorbato de potássio + sacarose, R Refrigeração, RSo - Refrigeração + sorbato de potássio, RSac - Refrigeração + sacarose, RSS Refrigeração + sorbato de potássio + sacarose. Média de duas repetições.

Médias seguidas da mesma letra na mesma coluna não diferem entre si significativamente ao nível de 5\% de significância pelo teste de Fisher. 
Observa-se que a redução do $\mathrm{pH}$ dos grupos coincide com a redução da viabilidade das bactérias probióticas dos mesmo. Segundo Thamer e Penna (2006), o pH interfere na viabilidade das cepas probióticas, e com o decréscimo deste, ocorre redução na população de células viáveis de Lactobacillus durante a estocagem refrigerada.

A estabilidade do $\mathrm{pH}$ do na condição refrigerada adicionada de sorbato de potássio pode ser explicada pelo fato do sorbato de potássio aumentar sua ação inibitória sobre bactérias quando em $\mathrm{pH}$ ácido, reduzindo o metabolismo dos Lactobacillus e consequentemente a síntese de ácido lático.

Como o decréscimo do $\mathrm{pH}$ pode ter influenciado os resultados encontrados na avaliação da população de células viáveis da preparação, se faz necessário o uso de estratégias que auxiliem no controle deste parâmetro.

De acordo com Ross, Desmond e Stanton (2005), o uso de cepas selecionadas com base em sua resistência a ácidos pode ser útil em aplicações probióticas, pois apresenta sobrevivência aumentada nas preparações mais ácidas. Outra estratégia seria o tamponamento da preparação em pH ideal para a manutenção das cepas probióticas (5,5 a 6,0) (COSTA, 2006), reduzindo assim a interferência da acidez na viabilidade destas bactérias. 


\section{CONCLUSÕES}

A emulsão base contendo monoestearato de glicerila, lanolina anidra, óleo mineral, Tween $80^{\circledR}$ e Spam $80^{\circledR}$, apresentou maior estabilidade no que se refere a separação de fases, formação de grumos e viscosidade e foi, portanto, selecionada para a formulação da preparação probiótica

Sorbato de potássio foi selecionado como agente conservante da preparação probiótica, pois apresentou menor interferência que o metilparabeno na taxa de sobrevivência das células de Lactobacillus e permite modular seu espectro de ação por meio do ajuste do $\mathrm{pH}$ do meio

A preparação probiótica quando submetida ao teste de estabilidade físico-química apresentou ausência de separação de fases, viscosidade aumentada, densidade e pH diminuídos.

A caracterização microbiológica da preparação probiótica revelou que a refrigeração é indispensável para a manutenção da viabilidade das bactérias probióticas;

A adição de $2 \%$ de sacarose à preparação probiótica a $4^{\circ} \mathrm{C}$ se mostrou eficaz na manutenção da população de células viáveis $\left(10^{8} \mathrm{UFC} / \mathrm{mL}\right)$ ao final dos 120 dias do ensaio;

A redução de $\mathrm{pH}$ da preparação influenciou negativamente na população de células viáveis nas condições estudadas, confirmando a necessidade da inclusão de um agente tamponante na formulação. 


\section{SUGESTÕES PARA TRABALHOS FUTUROS}

Avaliar o efeito de um agente tamponante nas características físico-químicas e microbiológica da preparação probiótica.

Avaliar a utilização das cepas de Lactobacillus microencapsuladas nas estabilidades físico-químicas e microbiológica da preparação probiótica.

Avaliar in vivo a eficácia da preparação probiótica na prevenção e cura no tratamento da mastite em bovinos de leite.

Avaliar a ação inibitória de bacteriocinas sobre as espécies patogênicas causadoras de mastite, bem como avaliar a sua inclusão nas preparações probióticas. 


\section{REFERÊNCIAS}

AGUILAR, A. P. Expressão de genes de Staphylococcus aureus em resposta as concentrações subinibitórias de antibióticos utilizados no tratamento da mastite bovina. 46p. Dissertação (Mestrado em Bioquímica Agrícola) - Universidade Federal de Viçosa, Viçosa, 2012.

AIRES, T. A. C. P. Mastites em bovinos: caracterização etiológica, padrões de sensibilidade e implementação de programas de qualidade do leite em explorações do Entre-Douro e Minho. 77 p. Dissertação (Mestrado em Medicina Veterinária) - Faculdade de Medicina Veterinária da Universidade Técnica de Lisboa, Lisboa, 2010.

ALBORNOZ, G. A. C. Evaluación del efecto biopreservador del Lactococcus lactis subsp. Lactis em queso blanco 55p. Dissertação (Mestrado em Ciência e Tecnologia de Alimentos) - Universidad del Zulia. Facultad de Ingeniería. División de Postgrado, Maracaibo, 2007.

ALMEIDA, L. A. B. Avaliação de tratamento homeopático com Phytolacca decandra 30CH durante a lactação de vacas com mastite subclínica. 94p. Tese (Doutorado em Medicina Veterinária) - Faculdade de Medicina Veterinária e Zootecnia, Universidade de São Paulo, São Paulo, 2009.

AlMEIDA, A. C.; SOARES, T. M. P.; SIlvA, D. B.; SILVA, B. C. M.; ALMEIDA, P. N. M.; SANTOS, C. A. Tratamento de mastite subclínica em bovinos utilizando bioterapia. Revista Brasileira de Agroecologia, v. 06, n. 2, p. 134 -141, 2011.

ALMEIDA, L. E. S.; GENARO, S. C.; GEROTI, T. C. S.; GALINA, N. M. F.; GIUFFRIDA, R.; PARDO, P. E.; PENHA, L.; CAMACH, R.; SANTOS, M. O. Utilização de probióticos sobre o ganho de peso em bovinos da raça nelore. Colloquium Agrariae., v.9, n. 1. 2013.

ALVIM, R.S. Programa de qualidade do leite no Brasil. Senado Federal. Audiência Pública. Disponível em: <http//www.senado.gov.br/sf/comissoes/cma/ap/ AP_20071107_CNA_ContaminacaoLeite.pdf>. Acesso em: 16 mar. 2014.

ANTUNES, A. E. C.; LISERRE, A. M.; ALVES, T. S.; SPADOTI, L. M.; MORENO, I.; ZACARCHENCO, P. B.; MENEZES, C. R. Viabilidade de culturas probióticas em Smoothie. Nutrire, v. 34, n. Suplemento, p. 60-60, 2009.

ANTUNES, A. E. C; MARASCA, E. T. G.; MORENO, I.; DOURADO, F. M.; RODRIGUES, L. G.; LERAYER, A. L. S. Desenvolvimento de buttermilk probiótico. Ciênc. Tecnol. Aliment., v.27, n.1, p. 83-90, 2007. 
ARAngO, H. G. - Bioestatística: Teórica e Computacional. Editora Guanabara

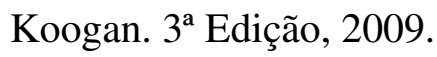

ARROYO, R.; MARTÍN, V.; MALDONADO, A.; JIMÉNEZ, E.; FERNÁNDEZ, L.; RODRÍGUEZ, J. M. Treatment of infectious mastitis during lactation: antibiotics versus oral administration of Lactobacilli isolated from breast milk. Clinical Infectious Diseases, v. 50, n. 12, p. 1551-1558, 2010.

BASKARAN, S. A.; KAZMER, G. W.; HINKLEY, L.; ANDREW, S. M.; VENKITANARAYANAN, K. Antibacterial effect of plant-derived antimicrobials on major bacterial mastitis pathogens in vitro. Journal of dairy science, v. 92, n. 4, p. 14231429, 2009.

BATISTUZZO, J.A.O.; ITAYA, M.; ETO, Y. Formulário médico-farmacêutico.Editora Tecnopress, $3^{\text {a }}$ Edição, 2006.

BRASIL, Agência Nacional de Vigilância Sanitária. Resolução da Diretoria Colegiada n² de 7 de janeiro de 2002. Diário Oficial União, Brasília, DF, 09 jan. 2002a.

BRASIL, Conjuntura do mercado lácteo. EMBRAPA, ano 5, n. 41, Juiz de Fora, 2012.

BRASIL, Guia de estabilidade de produtos cosméticos, Brasília: Agência Nacional de Vigilância Sanitária, 2004.

BRASIL. Ministério da Agricultura, Pecuária e Abastecimento. Instrução normativa ${ }^{\circ} 15$ de 9 de maio de 2005. Diário Oficial União, Brasília, DF, 12 mai. 2005.

BRASIL. Ministério da Agricultura, Pecuária e Abastecimento. Instrução Normativa no 51, de 18 de setembro de 2002. Diário Oficial da União, Brasília, DF, 20 set. 2002b.

BRASIL. Ministério da Agricultura, Pecuária e Abastecimento. Instrução Normativa no 62, de 29 de dezembro de 2011. Diário Oficial da União, Brasília, DF, 30 dez. 2011.

BRASIL. Legislação de produtos veterinários. Ministério da Agricultura, Pecuária e Abastecimento, 2014 Disponível em: < http://www.agricultura.gov.br/animal/produtosveterinarios/legislacao $>$. Acesso em: 16 mar. 2014.

BRITO, J. R. F., SALES, R. O. Saúde do úbere. uma revisão. Revista Brasileira de Higiene e Sanidade Animal, v. 01, n. 1, p. 67 - 90, 2007. 
CAPANEMA, L. X. L.; VElASCO, O. M. V.; SOUZA, J. O. B.; NOGUTI, M. B. Panorama da indústria farmacêutica veterinária. BNDES Setorial (Rio de Janeiro), n. 25, p. 157-174, 2007.

CASTELI, V. C.; MENDONÇA C. C.; CAMPOS, M. A.; CAMPOS, L.; FERRARI M.; MACHADO, S. R. P. Desenvolvimento e estudos de estabilidade preliminares de emulsões O/A contendo Cetoconazol 2,0\%. Acta Sci. Health Sci., v. 30, n. 2, p. 121-128, 2008

COELHO, V. R. P. Avaliação de resíduos de antimicrobiano no leite de quartos mamários não tratados de vacas com mastite tratadas por via intramamária. 102p. Dissertação (Mestrado) - Faculdade de Zootecnia e Engenharia de Alimentos Universidade de São Paulo, Pirassununga - SP, 2003.

COPPOLA, M. M.; TURNES, C. G. Probióticos e resposta imune. Ciência Rural, v. 34, n. 4, p. 1297-1303, 2004.

CORR, S. C.; LI, Y.; RIEDEL, C. U.; O'TOOLE, P. W.; HILL, C.; GAHAN, C. G. Bacteriocin production as a mechanism for the antiinfective activity of Lactobacillus salivarius UCC118. Proceedings of the National Academy of Sciences, v. 104, n. 18, p. 7617-7621, 2007.

COSTA, V. M. Perfil de metabólitos excretados por Lactobacillus isolados de processos industriais de produção de etanol, com ênfase nos isômeros óticos $D$ (-) e $\mathbf{L}$ (+) do ácido lático. 65p. Dissertação (Mestrado em Ciência e tecnologia de alimentos) Escola Superior de Agricultura Luiz de Queiroz, Universidade de São Paulo, Piracicaba, 2006 .

DYCE, K. M.; WENSING, C. J. G.; SACK, W. O. Tratado de anatomia veterinária, 4. ed. Rio de Janeiro: Elsevier Brasil, 2010.

ESPECHE, M.; PELLEGRINO, M.; FROLA, I.; LARRIESTRA, A.; BOGNI, C.; NADER-MACIAS, M. E. Lactic acid bacteria from raw milk as potentially beneficial strains to prevent bovine mastitis. Anaerobe, v. 18, n. 1, p. 103-109, 2012.

EURELL, J. A., FRAPPIER, B. L. Histologia veterinária de Dellmann, 6. Ed., Barueri: Editora Manole, Brasil, 2012.

FARIA, M. C. Fisiologia do úbere. 2014. Disponível em: <http://xa.yimg.com/kq/groups/13765267/1593396731/>. Acesso em: 14 jun. 2015.

FARMACOPÉIA Brasileira. 5.ed. São Paulo: Atheneu, 2010. 
FARMACOPÉIA Portuguesa. 8.ed. Lisboa: Infarmed, 2005

FERREIRA, A. O.; BRANDÃO, M. Guia prático da farmácia magistral, 3.ed, Juiz de Fora: Pharmabooks Editora, 2008.

FRASER, C. M. Manual Merk de Veterinária: Um manual de diagnóstico, tratamento, prevenção e controle de doenças para veterinária. 8. ed. São Paulo: Roca, 2001.

FROLA, I. D.; PELLEGRINO, M. S.; ESPECHE, M. C.; GIRAUDO, J. A.; NADERMACIAS, M. E.; BOGNI, C. I. Effects of intramammary inoculation of Lactobacillus perolens CRL1724 in lactating cows' udders. Journal of Dairy Research, v. 79, n. 01, p. 84-92, 2012.

FULLER, R. Probiotics in man and animals. Journal of Applied Bacteriology, Oxford, v.66, n.5, p.365-378, 1989.

GONÇALVES, C. L.; SCHUBERT, R. N.; FACCIN, A.; MOTA, F., SCHUCH, L. F. D. Óleo essencial de murta (Blepharocalyx salicifolius (Kunth) O. Berg) como alternativa no tratamento de mastite bovina. Cadernos de Agroecologia, v. 8, n. 2, 2013.

HONORATO, L. A. A interação humano - animal e o uso de homeopatia em bovinos de leite. 120f. Dissertação (Mestrado em Agroecossistemas) - Universidade Federal de Santa Catarina, Florianópolis, 2006.

INSTITUTO BRASILEIRO DE GEOGRAFIA E ESTATÍSTICA, Estatística da produção pecuária: Quarto trimestre de 2014. 2015. Disponível em: http://www.ibge.gov.br/home/estatistica/indicadores/agropecuaria/producaoagropecuaria/a bate-leite-couro-ovos_201404_publ_completa.pdf. Acesso em 14 jun. 2015.

JIMÉNEZ, E.; FERNÁNDEZ, L.; MALDONADO, A.; MARTÍN, R.; OLIVARES, M.; XAUS, J.; RODRÍGUEZ, J. M. Oral administration of Lactobacillus strains isolated from breast milk as an alternative for the treatment of infectious mastitis during lactation. Applied and environmental microbiology, v. 74, n. 15, p. 4650-4655, 2008.

KIM, S. Y.; SHIN, S.; KOO, H. C.; YOUN, J. H.; PAIK, H. D.; PARK, Y. H. n vitro antimicrobial effect and in vivo preventive and therapeutic effects of partially purified lantibiotic lacticin NK34 against infection by Staphylococcus species isolated from bovine mastitis. Journal of dairy science, v. 93, n. 8, p. 3610-3615, 2010.

KOTZAMANIDIS, C.; KOURELIS, A.; LITOPOULOU-TZANETAKI, E.; TZANETAKIS N.; YIANGOU, M. Evaluation of adhesion capacity, cell surface traits and 
immunomodulatory activity of presumptive probiotic Lactobacillus strains. International Journal of Food Microbiology, v. 140, n. 2, p. 154-163, 2010.

LIMA, C. G.; VILELA, A. F. G.; SILVA, A. A. S.; PIANNOVSKI, A. R.; SILVA, K. K.; CARVALHO, V. F. M; MUSIS, C. R.; MACHADO, S. R.; FERRARI, M. Desenvolvimento e avaliação da estabilidade física de emulsões O/A contendo óleo de babaçu (Orbignya oleifera). Revista Brasileira de Farmácia, v. 89, n. 3, p. 239-245, 2008 .

LINN, L. L.; MATHIESEN, R. J. Method for treatment and prevention of mastitis. U.S. Patent n. 4,591,499, 27 maio 1986.

MACEDO, L. N.; LUCHESE, R. H.; GUERRA, A. F.; BARBOSA, C. G. Efeito prebiótico do mel sobre o crescimento e viabilidade de Bifidobacterium spp. e Lactobacillus spp. em leite. Ciência e Tecnologia de Alimentos, v. 28, n. 4, p. 935-942, 2008 .

MARTINS, C. R.; VIEIRA, E. C.; GAZIM, Z. C.; MASSAMBANI, C. Tratamento de mastite subclínica por meio de suplementação mineral homeopática da dieta de vacas leiteiras em lactação-estudo de caso. Cultura Homeopática, v. 19, p. 16-19, 2007.

MAZURECHEN, L. Uso de medicamentos e a presença de resíduos destes no leite do rebanho leiteiro do Município de São José dos Pinhais - PR. 54f. Dissertação (Mestrado em Ciências veterinárias) - Universidade Federal do Paraná, Curitiba, 2005.

MEDEIROS, E. S.; SANTOS, M. V.; WILTON, J.; PINHEIRO JÚNIOR, E. B. D. F.; WANDERLEY, G. G.; TELES, A. A.; MOTA, R. A. Avaliação in vitro da eficácia de desinfetantes comerciais utilizados no pré e pós-dipping frente amostras de Staphylococcus spp. isoladas de mastite bovina1. Pesq. Vet. Bras, v. 29, n. 1, p. 71-75, 2009.

MENDONÇA, A.; MORAES, S. Relato de Experiência no Tratamento de Mastite Clínica de Vaca Leiteira com Homeopatia, no Município de Cruzaltense-RS. Rev. Bras. De Agroecologia, Vol. 4, No. 2, 2009a.

MENDONÇA, C.C.; SILVA, I.C.L.; RODRIGUES, K.A.; CAMPOS, M.A.L.; MEDEIROS, M.C.M.; CASTELI, V.C.; FERRARI, M., MUSIS, C.R.; MACHADO, S.R.P. Emulsões O/A contendo Cetoconazol 2,0\%: avaliação da estabilidade acelerada. Rev Ciênc Farm Básica Apl., Vol. 30, p. 35-46, 2009 b.

MENEZES, L. A. A.; DRUNKLER, D. A. Viabilidade de Lactobacillus Acidophilus microencapsulado por proteína de soja durante Armazenamento: efeito do pré-tratamento da cultura. In: CONGRESSO LATINOAMERICANO DE MICROBIOLOGIA E 
HIGIENE DE ALIMENTOS - MICROAL 2014, (Blucher Food Science Proceedings, n.1, v.1.) Anais São Paulo: Editora Blucher, 2014.

MORAIS, M. B.; JACOB, C. M. A. O papel dos probióticos e prebióticos na prática pediátrica. Jornal de Pediatria, v. 82, n. 5, p. S189-S197, 2006.

MÜLLER, E. E. Qualidade do leite, células somáticas e prevenção da mastite. Simpósio sobre Sustentabilidade da Pecuária Leiteira na Região Sul do Brasil, v. 2, p. 206-217, 2002.

NERO, L. A.; MATTOS, M.; BELOTI, V.; BARROS, M. A.; FRANCO, B. D. G. M. Resíduos de antibióticos em leite cru de quatro regiões leiteiras no Brasil. Cienc Tecnol Aliment, v. 27, n. 2, p. 391-393, 2007.

NOGUEIRA, J. C. R.; GONÇALVES, M. D. C. R. Probióticos-revisão da literatura. Revista Brasileira de Ciências da Saúde, v. 15, n. 4, p. 487-492, 2011.

OLIVER, S. P.; MURINDA, S. E. Antimicrobial resistance of mastitis pathogens. Veterinary Clinics of North America: Food Animal Practice, v. 28, n. 2, p. 165-185, 2012.

OLIVEIRA, A. C. Viabilidade de Lactobacillus acidophilus e Bifidobacterium latis, microencapsulados por coarcevação, seguida de secagem por spray drying e leito de jorro. 77p. Dissertação (Mestrado em Ciências Farmacêuticas) - Faculdade de Ciências Farmacêuticas de Ribeirão Preto, Universidade de São Paulo, Ribeirão Preto, 2006.

OLIVEIRA, C. B.; Utilização na indústria farmacêutica de vidro e pet em frascos de xarope. 40p. Monografia (Pós-graduação em Engenharia de processos industriais) Centro Universitário do Instituto Mauá de Tecnologia, São Caetano do Sul, 2011.

OMGE. ORGANIZAÇÃO MUNDIAL DE GASTROENTEROLOGIA. Guias práticas: probióticos e prebióticos. [s.1.]: [s.n.], 2008.

PEREIRA, A. V.; RODRIGUES, O. G.; AZEVEDO, T. K. B.; BEZERRA, D. A. C.; LIMA, E. Q.; PEREIRA, M. S. Perfil de extrato de plantas sobre Staphylococcus aureus isolado de mastite bovina. Revista de Biologia e Farmácia, v. 3, p. 1-5, 2009.

PERES NETO, F.; ZAPPA, V. Mastite em vacas leiteiras - revisão de literatura. Revista Científica Eletrônica de Medicina Veterinária. 16: 1-28, 2011.

PIVARO, J. Setor forte e com futuro próspero. Revista Indústria de Laticínios. v. 01, n. 109, p. $18-22,2014$. 
QUINN, P.J; MARKEY, B.K; CARTER, M.E; DONNELLY, W.J; LEONARD, F.C. Microbiologia veterinária e doenças infecciosas. Porto Alegre: Editora ARTMED, 2005

RAMOS, S. V. V. Validação da metodologia analítica aplicada ao controle da qualidade microbiológica de formas farmacêuticas líquidas e determinação da eficácia dos conservantes. 164p. Tese (Doutorado em Produção e Controle de Qualidade de Medicamentos) - Universidade Federal de Pernambuco, Recife, 2010.

REDONDO, N. C. Avaliação in vitro de características probióticas do Enterococcus faecium CRL183 e do Lactobacillus helveticus ssp jugurti 416. 109p. Dissertação (Mestrado em Alimentos e Nutrição) - Faculdade de Ciências Farmacêuticas, Universidade Estadual Paulista "Júlio Mesquita Filho", Araraquara, 2008.

REIS, S. R.; SILVA, N.; BRESCIA, M. V. Antibiotic therapy for subclinical mastitis control of lactating cows. Arquivo Brasileiro de Medicina Veterinária e Zootecnia, v.55, n.6, p.651- 658, 2003.

RIEGER, M. M. Teste de estabilidade para macroemulsões. Cosmet Toiletries, n.8, p.4753, 1996.

RODRIGUES, F. P. L. M. Desenvolvimento e Caracterização de Óvulos de Lactobacillus Acidophilus. 101p. Dissertação (Mestrado em Controle de Qualidade de Produtos Cosméticos e Higiene Corporal) - Faculdade de Farmácia, Universidade do Porto, Porto, 2011.

ROSS, R.P.; DESMOND, C.; STANTON, C. Overcoming the technological hurdles in the development of probiotic foods. J. Appl. Microbiol., v.98, p.1410-1417, 2005.

ROWE, R. C.; SHESKEY, P. J.; OWEN, S. C. Handbook of pharmaceutical excipients, 5.ed, Washington: Pharmaceutical Press, 2006.

SANTOS, A. F. S. Perfil microbiológico e ocorrência de resíduos de antimicrobianos em amostras de leite bovino em propriedades da região de campinas - SP. 80p. Dissertação (Mestrado em Produção Animal Sustentável) - Instituto de Zootecnia APTA/SAA, Nova Odessa - SP, 2010.

SEALE, J. V.; MILLAR, M. Probiotics: a new frontier for infection control. Journal of Hospital Infection, v. 84, n. 1, p. 1-4, 2013.

SERNA, L.; VALENCIA, L. J; CAMPOS, R. Lactic acid bacteria with antimicrobial activity against pathogenic agent causing of bovine mastitis. Biotecnología en el Sector Agropecuario y Agroindustrial, v. 9, n. 1, p. 97-104, 2011. 
SIDAN - SINDICATO NACIONAL DA INDÚSTRIA DE PRODUTOS PARA SAÚDE ANIMAL. Mercado de produtos veterinários. 2014. Disponível em: <http://www.sindan.org.br/sd/base.aspx?controle=8>. Acesso em: 17 jun. 2015.

SMITH, B. Tratado de Medicina Interna de Grandes Animais. V.2, São Paulo: Manole, 1994.

SOLEIMANI, N. A.; KERMANSHAHI, R. K.; YAKHCHALI, B.; NEJAD, T. Antagonistic activity of probiotic lactobacilli against Staphylococcus aureus isolated from bovine mastitis. African Journal of Microbiology Research, v.4, n. 20, p. 2169-2173, 2010 .

THAMER, K. G.; PENNA, A. L. B. Caracterização de bebidas lácteas funcionais fermentadas por probióticos e acrescidas de prebiótico. Ciênc. Tecnol. Aliment., Campinas, 26(3): 589-595, 2006.

THOMPSON, J. E. A prática farmacêutica na manipulação de medicamentos, $1^{\mathrm{a}}$.ed, Porto Alegre: Artmed, 2006.

VELASCO, M. V. R.; MACIEL, C. P. M.; SARRUF, F. D.; PINTO, C. A. S .O.; CONSIGLIERI, V. O.; KANEKO, T. M.; BABY, A. R. Desenvolvimento e teste preliminar da estabilidade de formulações cosméticas acrescidas de extrato comercial de Trichilia catigua Adr. Juss (e) Ptychopetalum olacoides Bentham. Rev. Ciênc. Farm. Básica Apl., v. 29, n.2, p. 181-196, 2008

VIEIRA, F. Efeito da lanolina anidra comparado ao leite materno combinado à concha de proteção para tratamento da dor e do trauma mamilar em lactantes. 170p. Tese (Doutorado em Enfermagem) - Faculdade de Enfermagem, Universidade Federal de Goiás, Goiânia, 2013. 


\section{APÊNDICE A}

\section{Seleção do conservante da preparação probiótica.}

Tabela I. Determinação da população de células viáveis (triplicata).

\begin{tabular}{|c|c|c|c|c|}
\hline Repetiçãa 1 & Inicial & 7 dias & 14 dias & 28 dias \\
\hline \multirow[t]{3}{*}{ Controle } & $3,4 \times 10^{8}$ & $1,4 \times 10^{9}$ & $4,2 \times 10^{7}$ & $4,7 \times 10^{7}$ \\
\hline & $4,0 \times 10^{8}$ & $1,4 \times 10^{9}$ & $4,7 \times 10^{7}$ & $6,1 \times 10^{7}$ \\
\hline & $3,7 \times 10^{8}$ & $1,4 \times 10^{9}$ & $5,5 \times 10^{7}$ & $6,2 \times 10^{7}$ \\
\hline \multirow[t]{3}{*}{ Metilparabeno } & $5,7 \times 10^{8}$ & $1,1 \times 10^{8}$ & $1,2 \times 10^{7}$ & $3,3 \times 10^{5}$ \\
\hline & $4,9 \times 10^{8}$ & $1,1 \times 10^{8}$ & $1,0 \times 10^{7}$ & $3,1 \times 10^{5}$ \\
\hline & $5,2 \times 10^{8}$ & $8,9 \times 10^{7}$ & $1,2 \times 10^{7}$ & $4,2 \times 10^{5}$ \\
\hline \multirow[t]{3}{*}{ Sorbato de potássio } & $2,9 \times 10^{8}$ & $1,7 \times 10^{8}$ & $5,9 \times 10^{6}$ & $4,3 \times 10^{5}$ \\
\hline & $3,3 \times 10^{8}$ & $1,6 \times 10^{8}$ & $6,7 \times 10^{6}$ & $4,8 \times 10^{5}$ \\
\hline & $2,1 \times 10^{8}$ & $1,4 \times 10^{8}$ & $4,8 \times 10^{6}$ & $5,0 \times 10^{5}$ \\
\hline Repetição 2 & Inicial & 7 dias & 14 dias & 28 dias \\
\hline \multirow[t]{3}{*}{ Controle } & $4,6 \times 10^{8}$ & $1,3 \times 10^{9}$ & $8,5 \times 10^{7}$ & $8,7 \times 10^{7}$ \\
\hline & $4,4 \times 10^{8}$ & $1,3 \times 10^{9}$ & $6,8 \times 10^{7}$ & $9,3 \times 10^{7}$ \\
\hline & $5,8 \times 10^{8}$ & $1,3 \times 10^{9}$ & $7,0 \times 10^{7}$ & $7,5 \times 10^{7}$ \\
\hline \multirow[t]{3}{*}{ Metilparabeno } & $9,3 \times 10^{8}$ & $1,1 \times 10^{8}$ & $1,1 \times 10^{7}$ & $3,3 \times 10^{5}$ \\
\hline & $8,5 \times 10^{8}$ & $1,0 \times 10^{8}$ & $1,1 \times 10^{7}$ & $3,1 \times 10^{5}$ \\
\hline & $6,5 \times 10^{8}$ & $1,3 \times 10^{8}$ & $1,2 \times 10^{7}$ & $3,5 \times 10^{5}$ \\
\hline \multirow[t]{3}{*}{ Sorbato de potássio } & $4,0 \times 10^{8}$ & $9,1 \times 10^{7}$ & $6,3 \times 10^{6}$ & $5,6 \times 10^{5}$ \\
\hline & $5,2 \times 10^{8}$ & $9,4 \times 10^{7}$ & $5,4 \times 10^{6}$ & $5,5 \times 10^{5}$ \\
\hline & $5,0 \times 10^{8}$ & $8,8 \times 10^{7}$ & $3,8 \times 10^{6}$ & $4,2 \times 10^{5}$ \\
\hline
\end{tabular}




\section{Avaliação da estabilidade físico química da emulsão base}

Tabela II. Valores de $\mathrm{pH}$, viscosidade e densidade (triplicata).

\begin{tabular}{|c|c|c|c|c|c|c|c|}
\hline pH & Inicial & 15 dias & 30 dias & 45 dias & 60 dias & 75 dias & 90 dias \\
\hline \multirow[t]{3}{*}{ Teste 1} & 4,43 & 3,86 & 3,78 & 3,63 & 3,65 & 3,63 & 3,60 \\
\hline & 4,35 & 3,87 & 3,77 & 3,63 & 3,69 & 3,64 & 3,59 \\
\hline & 4,36 & 3,90 & 3,77 & 3,66 & 3,70 & 3,64 & 3,66 \\
\hline \multirow[t]{3}{*}{ Teste 2} & 4,38 & 3,69 & 3,59 & 3,57 & 3,58 & 3,55 & 3,55 \\
\hline & 4,42 & 3,75 & 3,59 & 3,54 & 3,58 & 3,52 & 3,55 \\
\hline & 4,42 & 3,76 & 3,59 & 3,54 & 3,59 & 3,52 & 3,54 \\
\hline $\begin{array}{c}\text { Viscosidade } \\
\left(\mathrm{mm}^{2} / \mathbf{s}\right)\end{array}$ & Inicial & 15 dias & 30 dias & 45 dias & 60 dias & 75 dias & 90 dias \\
\hline \multirow[t]{3}{*}{ Teste 1} & 59,93 & 29,98 & 37,41 & 33,06 & 33,06 & 36,88 & 55,60 \\
\hline & 61,51 & 29,98 & 29,98 & 44,53 & 44,53 & 36,88 & 55,60 \\
\hline & 61,51 & 33,13 & 39,44 & 44,53 & 29,23 & 44,53 & 59,82 \\
\hline \multirow[t]{3}{*}{ Teste 2} & 66,24 & 41,01 & 36,39 & 50,47 & 56,50 & 56,00 & 78,94 \\
\hline & 72,54 & 41,01 & 36,29 & 45,74 & 56,50 & 52,18 & 94,24 \\
\hline & 72,54 & 45,74 & 41,01 & 53,63 & 56,50 & 63,65 & 86,59 \\
\hline $\begin{array}{c}\text { Densidade } \\
(\mathrm{g} / \mathrm{mL})\end{array}$ & Inicial & 15 dias & 30 dias & 45 dias & 60 dias & 75 dias & 90 dias \\
\hline \multirow[t]{3}{*}{ Teste 1} & 0,9930 & 0,9886 & 0,9888 & 0,9828 & 0,9793 & 0,9530 & 0,9381 \\
\hline & 0,9920 & 0,9901 & 0,9889 & 0,9836 & 0,9807 & 0,9537 & 0,9349 \\
\hline & 0,9925 & 0,9911 & 0,9879 & 0,9847 & 0,9799 & 0,9528 & 0,9324 \\
\hline \multirow[t]{3}{*}{ Teste 2} & 0,9955 & 0,9957 & 0,9933 & 0,9918 & 0,9836 & 0,9784 & 0,9683 \\
\hline & 0,9961 & 0,9937 & 0,9937 & 0,9913 & 0,9825 & 0,9763 & 0,9710 \\
\hline & 0,9949 & 0,9945 & 0,9929 & 0,9906 & 0,9816 & 0,9771 & 0,9671 \\
\hline
\end{tabular}




\section{Avaliação da estabilidade microbiológica da preparação probiótica.}

Tabela III. Determinação da população de células viáveis (duplicata) - primeira repetição.

\begin{tabular}{lccccc}
\hline & Inicial & 30 dias & 60 dias & 90 dias & 120 dias \\
\hline TA & $3,3 \times 10^{8}$ & $3,7 \times 10^{5}$ & $3,5 \times 10^{2}$ & 0 & 0 \\
& $3,5 \times 10^{8}$ & $5,1 \times 10^{5}$ & $2,9 \times 10^{2}$ & 0 & 0 \\
TASo & $3,9 \times 10^{8}$ & $3,7 \times 10^{5}$ & $0,9 \times 10$ & 0 & 0 \\
& $2,9 \times 10^{8}$ & $2,9 \times 10^{5}$ & $0,6 \times 10$ & 0 & 0 \\
TASac & $5,0 \times 10^{7}$ & $7,7 \times 10^{5}$ & $2,2 \times 10$ & 0 & 0 \\
& $3,5 \times 10^{7}$ & $6,2 \times 10^{5}$ & $1,3 \times 10$ & 0 & 0 \\
TASS & $2,1 \times 10^{8}$ & $3,9 \times 10^{5}$ & $1,1 \times 10$ & 0 & 0 \\
& $2,3 \times 10^{8}$ & $2,6 \times 10^{5}$ & $0,8 \times 10$ & 0 & $0,6 \times 10^{6}$ \\
& $3,3 \times 10^{8}$ & $5,0 \times 10^{8}$ & $7,2 \times 10^{7}$ & $7,6 \times 10^{7}$ & $6,3 \times 10^{5}$ \\
RSS & $3,5 \times 10^{8}$ & $3,3 \times 10^{8}$ & $6,8 \times 10^{7}$ & $4,5 \times 10^{7}$ & $7,2 \times 10^{6}$ \\
& $2,3 \times 10^{8}$ & $3,3 \times 10^{8}$ & $8,9 \times 10^{7}$ & $5,8 \times 10^{7}$ & $3,7 \times 10^{5}$
\end{tabular}

Legenda: TA - Temperatura ambiente, TASo - Temperatura ambiente + Sorbato de Potássio, TASac Temperatura ambiente + Sacarose, TASS - Temperatura ambiente + Sorbato de Potássio + Sacarose, $\mathrm{R}-$ Refrigeração, RSo - Refrigeração + Sorbato de Potássio, RSac - Refrigeração + Sacarose, RSS Refrigeração + Sorbato de Potássio + Sacarose. 
Tabela IV. Determinação da população de células viáveis (duplicata) - segunda repetição.

\begin{tabular}{|c|c|c|c|c|c|}
\hline & Inicial & 30 dias & 60 dias & 90 dias & 120 dias \\
\hline \multirow{2}{*}{ TA } & $1,1 \times 10^{9}$ & $1,9 \times 10^{7}$ & $9,2 \times 10^{4}$ & $8,9 \times 10$ & $2,2 \times 10$ \\
\hline & $1,6 \times 10^{9}$ & $1,9 \times 10^{7}$ & $6,0 \times 10^{4}$ & $1,2 \times 10^{2}$ & $2,6 \times 10$ \\
\hline \multirow{2}{*}{ TASo } & $1,5 \times 10^{9}$ & $4,8 \times 10^{7}$ & $4,2 \times 10^{2}$ & $7,3 \times 10^{2}$ & 0 \\
\hline & $1,4 \times 10^{9}$ & $3,2 \times 10^{7}$ & $2,5 \times 10^{2}$ & $6,0 \times 10^{2}$ & 0 \\
\hline \multirow{2}{*}{ TASac } & $1,4 \times 10^{9}$ & $9,8 \times 10^{6}$ & $7,7 \times 10^{4}$ & $3,4 \times 10$ & $2,1 \times 10$ \\
\hline & $1,2 \times 10^{9}$ & $9,4 \times 10^{6}$ & $6,3 \times 10^{4}$ & $2,3 \times 10$ & $1,7 \times 10$ \\
\hline \multirow{2}{*}{ TASS } & $8,4 \times 10^{8}$ & $4,8 \times 10^{7}$ & $3,9 \times 10^{4}$ & $3,7 \times 10$ & $0,3 \times 10$ \\
\hline & $6,8 \times 10^{8}$ & $2,8 \times 10^{7}$ & $2,5 \times 10^{4}$ & $2,0 \times 10$ & $0,6 \times 10$ \\
\hline \multirow{2}{*}{$\mathrm{R}$} & $1,1 \times 10^{9}$ & $3,0 \times 10^{8}$ & $5,1 \times 10^{7}$ & $3,2 \times 10^{7}$ & $3,6 \times 10^{6}$ \\
\hline & $1,6 \times 10^{9}$ & $3,9 \times 10^{8}$ & $6,2 \times 10^{7}$ & $3,6 \times 10^{7}$ & $4,1 \times 10^{6}$ \\
\hline \multirow[t]{2}{*}{ RSo } & $1,5 \times 10^{9}$ & $8,7 \times 10^{8}$ & $8,0 \times 10^{8}$ & $8,3 \times 10^{7}$ & $4,7 \times 10^{6}$ \\
\hline & $1,4 \times 10^{9}$ & $6,8 \times 10^{8}$ & $6,7 \times 10^{8}$ & $7,9 \times 10^{7}$ & $6,2 \times 10^{6}$ \\
\hline \multirow[t]{2}{*}{ RSac } & $1,4 \times 10^{9}$ & $2,2 \times 10^{9}$ & $3,1 \times 10^{8}$ & $3,7 \times 10^{8}$ & $2,4 \times 10^{8}$ \\
\hline & $1,2 \times 10^{9}$ & $2,4 \times 10^{9}$ & $3,6 \times 10^{8}$ & $4,1 \times 10^{8}$ & $3,9 \times 10^{8}$ \\
\hline \multirow{2}{*}{ RSS } & $8,4 \times 10^{8}$ & $5,3 \times 10^{8}$ & $4,4 \times 10^{8}$ & $4,7 \times 10^{7}$ & $5,9 \times 10^{6}$ \\
\hline & $6,8 \times 10^{8}$ & $6,5 \times 10^{8}$ & $3,7 \times 10^{8}$ & $3,5 \times 10^{7}$ & $3,1 \times 10^{6}$ \\
\hline
\end{tabular}

Legenda: TA - Temperatura ambiente, TASo - Temperatura ambiente + Sorbato de Potássio, TASac Temperatura ambiente + Sacarose, TASS - Temperatura ambiente + Sorbato de Potássio + Sacarose, $R-$ Refrigeração, RSo - Refrigeração + Sorbato de Potássio, RSac - Refrigeração + Sacarose, RSS Refrigeração + Sorbato de Potássio + Sacarose. 
Tabela V. Valores de pH das diferentes formulações da preparação probiótica estabilidade

\begin{tabular}{lccccc}
\hline Repetição 1 & Inicial & 30 dias & 60 dias & 90 dias & 120 dias \\
\hline TA & 4,60 & 3,23 & 2,89 & 2,65 & 2,65 \\
\hline TASo & 4,65 & 3,38 & 3,06 & 2,88 & 2,84 \\
\hline TASac & 4,58 & 3,21 & 2,85 & 2,45 & 2,45 \\
\hline TASS & 4,64 & 3,41 & 3,05 & 2,72 & 2,72 \\
\hline R & 4,60 & 4,15 & 3,63 & 3,59 & 3,56 \\
\hline RSo & 4,65 & 4,23 & 4,08 & 4,15 & 4,11 \\
\hline RSac & 4,58 & 3,88 & 3,28 & 3,03 & 2,99 \\
\hline RSS & 4,64 & 4,29 & 3,85 & 3,32 & 3,28
\end{tabular}

\begin{tabular}{lccccc}
\hline Repetição 2 & Inicial & 30 dias & 60 dias & 90 dias & 120 dias \\
\hline TA & 4,47 & 2,25 & 2,22 & 2,20 & 2,36 \\
\hline TASo & 4,12 & 2,55 & 2,38 & 2,27 & 2,25 \\
\hline TASac & 4,08 & 2,15 & 2,12 & 2,12 & 2,23 \\
\hline TASS & 4,16 & 2,28 & 2,17 & 2,15 & 2,15 \\
\hline R & 4,47 & 3,17 & 3,10 & 3,05 & 3,09 \\
\hline RSo & 4,12 & 3,56 & 3,46 & 3,62 & 3,52 \\
\hline RSac & 4,08 & 3,27 & 3,25 & 3,18 & 3,17 \\
\hline RSS & 4,16 & 3,35 & 3,28 & 3,26 & 3,21
\end{tabular}

Legenda: TA - Temperatura ambiente, TASo - Temperatura ambiente + Sorbato de Potássio, TASac Temperatura ambiente + Sacarose, TASS - Temperatura ambiente + Sorbato de Potássio + Sacarose, R Refrigeração, RSo - Refrigeração + Sorbato de Potássio, RSac - Refrigeração + Sacarose, RSS Refrigeração + Sorbato de Potássio + Sacarose. 
APÊNDICE B

Resultados da análise estatística da seleção do conservante

Tabela I. Análise estatística da determinação da população de células viáveis.

\begin{tabular}{ccccc}
\hline & \multicolumn{4}{|c}{ Parametrização (dados descritivos) } \\
\hline & Média & DesvPad & Variância & CV \\
\hline Controle & $4,78 \mathrm{E}+08$ & 549.646 .865 & $3,03 \mathrm{E}+17$ & 1,15057 \\
Nipagim & $1,97 \mathrm{E}+08$ & 290.725 .402 & $8,88 \mathrm{E}+16$ & 1,46461 \\
Sorbato & $1,26 \mathrm{E}+08$ & 163.922 .003 & $2,85 \mathrm{E}+16$ & 1,27832 \\
\hline
\end{tabular}

Tabela II. Teste de Fisher dos valores da determinação da população de células viáveis.

\begin{tabular}{lccc}
\hline \multicolumn{3}{c}{ MATRIZ DE COMPARAÇÃO (T. FISHER) } \\
\hline \multirow{2}{*}{ CONTROLE } & NIPAGIM & SORBATO \\
\cline { 2 - 4 } CONTROLE & 0,003182 & 0,002207 \\
NIPAGIM & & 0,068083 \\
SORBATO & & & \\
\hline
\end{tabular}

Tabela III. Análise estatística dos valores de pH.

\begin{tabular}{ccccc}
\hline \multicolumn{5}{c}{ Parametrização (dados descritivos) } \\
\hline Média & DesvPad & Variância & CV \\
\hline Controle & 6,59750 & 0,16464 & 0,02711 & 0,02496 \\
Nipagim & 5,47250 & 0,88116 & 0,77645 & 0,16102 \\
Sorbato & 5,51125 & 0,98676 & 0,97370 & 0,17904 \\
\hline
\end{tabular}


Tabela IV. Teste de Fisher dos valores de pH.

\begin{tabular}{lccc}
\hline \multicolumn{3}{c}{ MATRIZ DE COMPARAÇÃO (T. FISHER) } \\
\hline \multicolumn{1}{c}{ CONTROLE } & NIPAGIM & SORBATO \\
\cline { 2 - 4 } CONTROLE & & 0,000245776 & 0,000115509 \\
NIPAGIM & & & 0,772818317 \\
SORBATO & & & \\
\hline
\end{tabular}

Resultados da análise estatística da estabilidade físico-química

Tabela V. Análise estatística dos valores de $\mathrm{pH}$, viscosidade e densidade.

\begin{tabular}{lrlrr}
\hline \multicolumn{5}{c}{ PARAMETRIZAÇÃO } \\
\hline & MÉDIA & \multicolumn{1}{l}{$\begin{array}{l}\text { Desvio } \\
\text { Padrão }\end{array}$} & Variância & CV \\
\hline pH & 3,753095 & 0,281186 & 0,079066 & 0,074921 \\
Viscosidade & 50,115 & 15,75808 & 248,317 & 0,314438 \\
Densidade & 0,980445 & 0,017069 & 0,000291 & 0,01741 \\
\hline
\end{tabular}




\section{Resultados da análise estatística da estabilidade microbiológica}

Tabela VI. Análise estatística dos valores da população de células viáveis nas diferentes formulações probióticas.

\begin{tabular}{lcccc}
\hline \multicolumn{5}{c}{ PARAMETRIZAÇÃO } \\
\hline \multicolumn{1}{c}{ GRUPO } & Média & Var & DP & CV \\
\hline TA & 68.088 .064 & $2,05601 \mathrm{E}+16$ & 361193900 & 2,110904 \\
TASo & 68.066 .002 & $2,10967 \mathrm{E}+16$ & 376623538 & 2,086833 \\
TASac & 8.639 .004 & $3,31073 \mathrm{E}+14$ & 283597700 & 2,101356 \\
TASS & 44.065 .002 & $8,62033 \mathrm{E}+15$ & 205922868 & 2,053114 \\
R & 178.480 .000 & $3,21615 \mathrm{E}+16$ & 365668106 & 1,273326 \\
Rso & 163.724 .000 & $3,02906 \mathrm{E}+16$ & 367020962 & 0,990789 \\
Rsac & 215.900 .000 & $3,91423 \mathrm{E}+16$ & 511422094 & 0,902796 \\
RSS & 154.480 .000 & $2,53526 \mathrm{E}+16$ & 238612537 & 0,956549 \\
\hline
\end{tabular}

Legenda: TA - Temperatura ambiente, TASo - Temperatura ambiente + Sorbato de potássio, TASac Temperatura ambiente + Sacarose, TASoSac - Temperatura ambiente + Sorbato de potássio + Sacarose, $\mathrm{R}-$ Refrigeração, RSo - Refrigeração + Sorbato de potássio, RSac - Refrigeração + Sacarose, RSoSac Refrigeração + Sorbato de potássio + Sacarose

Tabela VII Teste de Fisher relativo aos fatores Temperatura e Adjuvantes na variação da população de células viáveis.

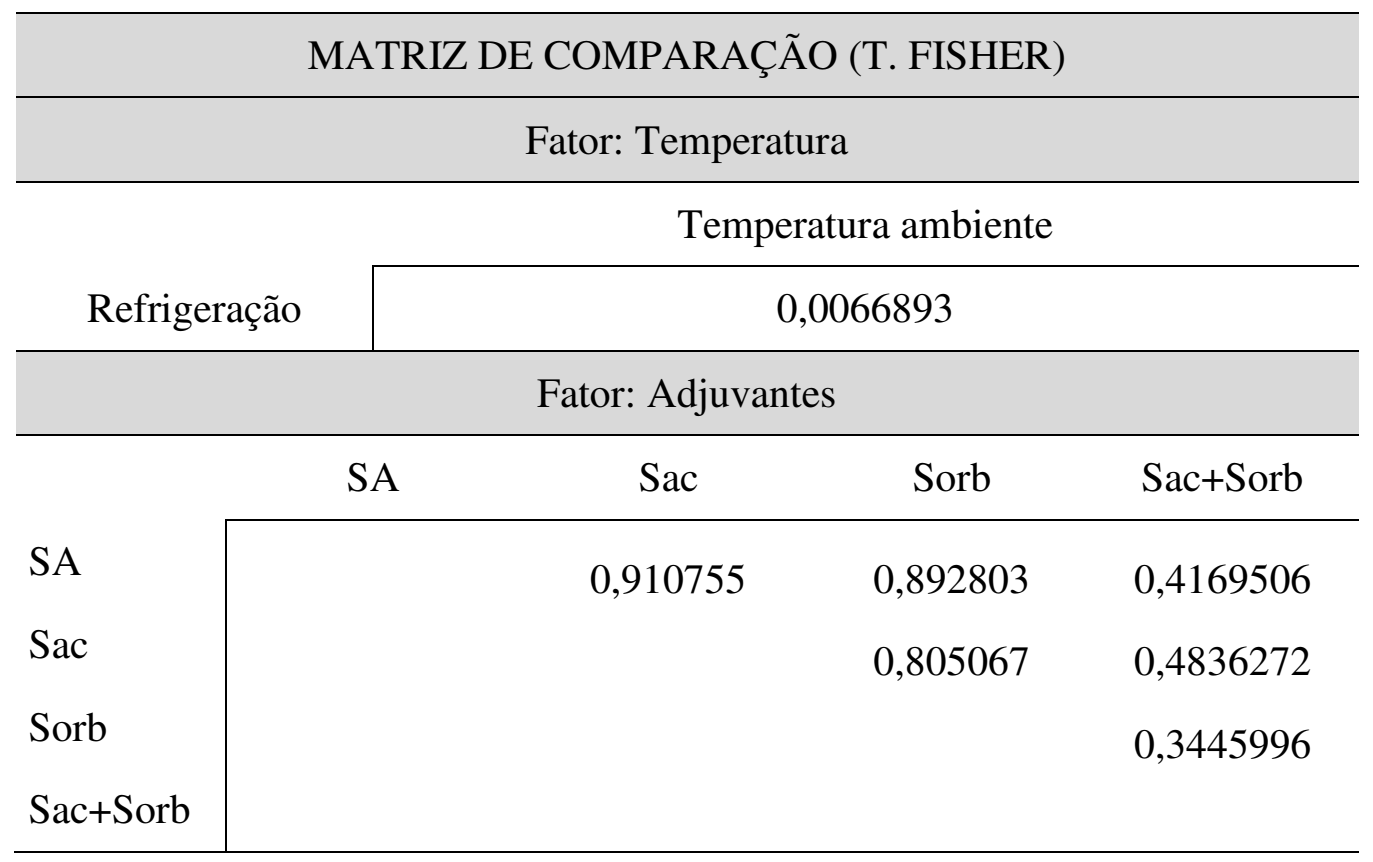

Legenda: SA - sem adjuvante, Sac - sacarose, Sorb - sorbato de potássio, Sac + Sorb - sacarose + sorbato. 
Tabela VIII. Análise estatística dos valores de pH.

\begin{tabular}{lcccc}
\hline \multicolumn{4}{c}{ PARAMETRIZAÇÃO } \\
& Média & Var & DP & CV \\
\hline TA & 2,7 & 0,98285 & 0,991388 & 0,367181 \\
TASo & 2,714 & 0,63193 & 0,79494 & 0,292904 \\
TASac & 2,54 & 0,74315 & 0,862061 & 0,339394 \\
TASS & 2,582 & 0,78107 & 0,883782 & 0,342286 \\
R & 3,376 & 0,37588 & 0,613091 & 0,181603 \\
Rso & 3,656 & 0,07068 & 0,265857 & 0,072718 \\
Rsac & 3,39 & 0,15065 & 0,388137 & 0,114495 \\
RSS & 3,452 & 0,15917 & 0,398961 & 0,115574 \\
\hline Legenda: TA - Temperatura ambiente, TASo - Temperatura ambiente + Sorbato de potássio, TASac - \\
Temperatura ambiente + Sacarose, TASS - Temperatura ambiente + Sorbato de potássio + Sacarose, R - \\
Refrigeração, RSo - Refrigeração + Sorbato de potássio, RSac - Refrigeração + Sacarose, RSS - \\
Refrigeração + Sorbato de potássio + Sacarose & & &
\end{tabular}

Tabela IX. Teste de Fisher relativo aos fatores Temperatura e Adjuvantes na variação do $\mathrm{pH}$.

\begin{tabular}{|c|c|c|c|}
\hline \multicolumn{4}{|c|}{ MATRIZ DE COMPARAÇÃO (T. FISHER) } \\
\hline \multicolumn{4}{|c|}{ Fator: Temperatura } \\
\hline \multicolumn{4}{|c|}{ Temperatura ambiente } \\
\hline Refrigeração & \multicolumn{3}{|c|}{0,004962} \\
\hline \multicolumn{4}{|c|}{ Fator: Adjuvantes } \\
\hline & $\mathrm{Sac}$ & Sorb & Sac+Sorb \\
\hline AS & 0,927177 & 0,467061 & 0,506486 \\
\hline Sac & & 0,436698 & 0,46919 \\
\hline Sorb & & & 0,676117 \\
\hline Sac+Sorb & & & \\
\hline
\end{tabular}

Legenda: SA - sem adjuvante, Sac - sacarose, Sorb - sorbato de potássio, Sac + Sorb - sacarose + sorbato. 